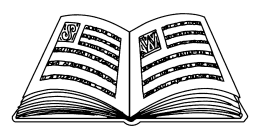

T E A M S

Western Michigan University Medieval Institute Publications/Arc Humanities Press

7-1-1997

\title{
Early Latin Commentaries on the Apocalypse
}

Francis X. Gumerlock

Archdiocese of Denver, Fxg1@comcast.net

Follow this and additional works at: https://scholarworks.wmich.edu/mip_teamscs

Part of the Biblical Studies Commons, Christianity Commons, and the Medieval Studies Commons

\section{Recommended Citation}

Gumerlock, Francis X., "Early Latin Commentaries on the Apocalypse" (1997). TEAMS Commentary Series. 8.

https://scholarworks.wmich.edu/mip_teamscs/8

This Edition and/or Translation is brought to you for free and open access by the Medieval Institute Publications at ScholarWorks at WMU. It has been accepted for inclusion in TEAMS Commentary Series by an authorized administrator of ScholarWorks at WMU. For more information, please contact wmuscholarworks@wmich.edu.

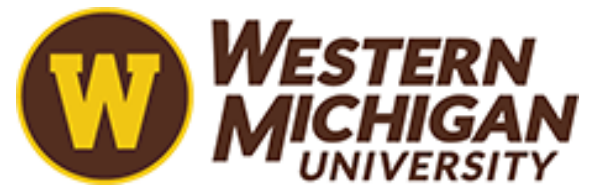




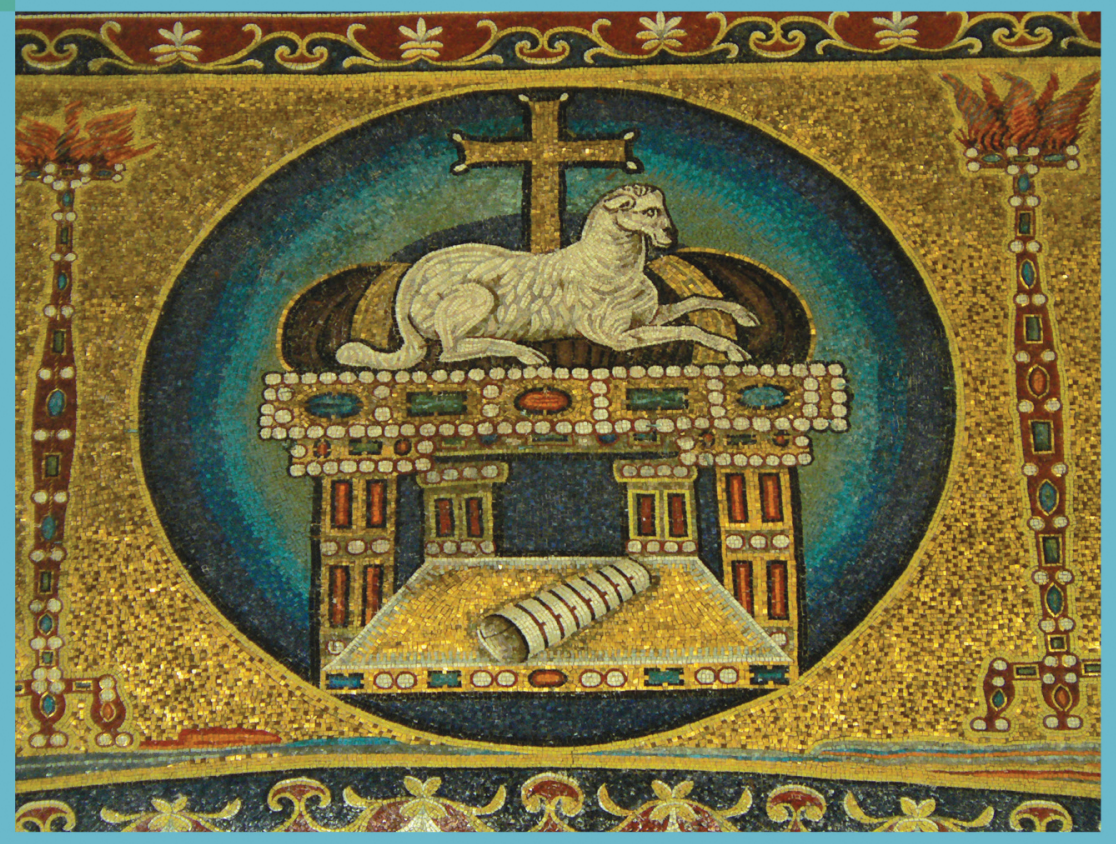

\section{EARLY LATIN COMMENTARIES ON THE APOCALYPSE}

Edited by

Francis X. Gumerlock 


\section{Early Latin Commentaries on the Apocalypse}




\title{
COMMENTARY SERIES
}

\author{
GENERAL EDITOR \\ E. Ann Matter, University of Pennsylvania
}

\author{
ADVISORY BOARD \\ John C. Cavadini, University of Notre Dame \\ Robert A. Harris, Jewish Theological Seminary \\ Patricia Hollahan, Western Michigan University \\ James J. O’Donnell, Georgetown University \\ Lesley J. Smith, Oxford University \\ Grover A. Zinn, Oberlin College
}

A list of the books in the series appears at the end of this book.

The Commentary Series is designed for classroom use. Its goal is to make available to teachers and students useful examples of the vast tradition of medieval commentary on sacred Scripture. The series will include English translations of works written in a number of medieval languages and from various centuries and religious traditions. The series focuses on treatises which have relevance to many fields of Medieval Studies, including theories of allegory and literature, history of art, music and spirituality, and political thought. Notes are meant to provide sources and to gloss difficult passages rather than to give exhaustive scholarly commentary on the treatise. The editions include short introductions which set the context and suggest the importance of each work.

Medieval Institute Publications is a program of The Medieval Institute, College of Arts and Sciences 


\title{
Early Latin Commentaries on the Apocalypse
}

\author{
Edited by
}

Francis X. Gumerlock

TEAMS • Commentary Series

MEDIEVAL INSTITUTE PUBLICATIONS

Western Michigan University

Kalamazoo 
Copyright (C) 2016 by the Board of Trustees of Western Michigan University

\section{The Library of Congress has already cataloged the paperback as follows:}

Names: Gumerlock, Francis X., editor.

Title: Early Latin commentaries on the Apocalypse / edited by Francis X. Gumerlock.

Other titles: TEAMS secular commentary series.

Description: Kalamazoo : Western Michigan University, 2016. | Series: TEAMS commentary series | English translations of two Latin commentaries on the Apocalypse from the seventh and eighth centuries. Identifiers: LCCN 2016012699 | ISBN 9781580442237 (pbk. : alk. paper)

Subjects: LCSH: Bible. Revelation--Commentaries--Early works to 1800. Classification: LCC BS2825.52 .E27 2016 | DDC 228/.07--dc23

LC record available at http://lccn.loc.gov/2016012699

ISBN: 9781580442237 (paperback) eISBN: 9781580442329 (PDF) 


\section{Contents}

Acknowledgements vii

Abbreviations $\quad$ ix

Introduction $\quad 1$

Pseudo-Jerome, Handbook on the Apocalypse of the Apostle John 21

Reference Bible, On the Mysteries in the Apocalypse of John 44

$\begin{array}{ll}\text { Bibliography } & 99\end{array}$ 
This page intentionally left blank. 


\section{Acknowledgements}

I would like to thank E. Ann Matter, general editor of the TEAMS Commentary Series of Medieval Institute Publications, for her encouragement and support of this project. Thank you also to Elizabeth Sollie, the interlibrary loan librarian at College Hill Library in Westminster, Colorado, for her help in procuring necessary resources. Many thanks also to Lesley Smith of the University of Oxford, Dr. Colin McAllister of the University of Colorado at Colorado Springs, and my wife Susan C. Gumerlock for their proofreading and very helpful suggestions. Finally, thank you to Thomas A. Croteau, who provided a first draft of the translation of the Apocalypse commentary in the Reference Bible during the summer of 2011. Thomas, a Jesuit scholastic, is pursuing graduate studies in philosophy at Saint Louis University after majoring in classics and early Christian literature at the undergraduate level. His previous translation work includes a large catechism by Edmond Auger, S.J., published in Christian Catechetical Texts, edited by William P. McDonald. 
This page intentionally left blank. 


\section{Abbreviations}

ACW Ancient Christian Writers: The Works of the Fathers in Translation. Edited by J. Quasten, J.C. Plumpe, W. J. Burghart, J. Dillon, and D.D. McManus. New York: Newman, 1946-present.

ANF Ante-Nicene Fathers of the Church. Edited by Alexander Roberts and James Donaldson. 10 vols. Buffalo: Christian Literature, 1885-96.

CCCM Corpus Christianorum, Continuatio Medievalis. Turnhout, Belgium: Brepols, 1953-present.

CCSL Corpus Christianorum, Series Latina. Turnhout, Belgium: Brepols, 1953-present.

CSEL Corpus Scriptorium Ecclesiasticorum Latinorum. Vienna: Hoelder-Pichler, Tempsky, 1866-present.

FC Fathers of the Church. New York: Cima, 1947-49; New York: Fathers of the Church, 1949-60; Washington, DC: Catholic University of America Press, 1960-present.

NPNF A Select Library of the Nicene and Post-Nicene Fathers of the Christian Church. Edited by Philip Schaff. 2 series of 14 vols. New York: Christian Literature, 1887-94. Numerous reprints by various publishing companies including T \& T Clark, Eerdmans, and Hendrickson.

PL Patrologiae cursus completus, series latina. Edited by Jacques-Paul Migne. 221 vols. Paris: Petit-Montrouge, 1844-1864. 
PLS Patrologiae latinae, supplementum. Edited by Adalbert Hamman. 5 vols. Paris: Garnier Frères, 1958-74.

SC Sources chrétiennes. Paris: Cerf, 1941-present. 


\section{Introduction}

This book contains English translations of two Hiberno-Latin commentaries on the Apocalypse from the early Middle Ages: the pseudo-Jerome Handbook on the Apocalypse of the Apostle John from the late seventh century, and an anonymous On the Mysteries of the Apocalypse of John contained in the eighth-century Reference Bible. The term "Hiberno-Latin" is meant to indicate that these texts were written in Latin by Irish authors, Hibernia being the Latin name for Ireland. This introduction will discuss the authorship, date, provenance, purpose, contents, sources, and unique features of both commentaries.

\section{Pseudo-Jerome, Handbook on the Apocalypse of the Apostle John}

The Handbook on the Apocalypse of the Apostle John (Commemoratorium de Apocalypsi Iohannis apostoli) is an anonymous seventh-century text falsely attributed to Jerome in several of the manuscripts and to Isidore of Seville in one manuscript. ${ }^{1}$ Roger Gyrson edited the Handbook in 2003 and the present translation is based on his edition. ${ }^{2}$ In the translation I have added chapters and verses to correspond with modern versions of the Book of Revelation.

\section{Purpose, Content, Genre}

The Handbook seems to have been intended as a quick reference guide for preachers. ${ }^{3}$ In it the words "to preach" (praedicare), "preacher" (praedicator), and "preaching" or "proclamation" (praedicatio) in their varied forms appear over forty times; and the command Go and pour out the seven bowls of the wrath of God into the earth (Rev 16:1) is interpreted as a command to preachers to preach the gospel. ${ }^{4}$

Bernhard Bischoff refers to the Handbook as "a primitive and sparse 
[...] allegorical exposition"5 probably because the comments in the Handbook consist of short glosses on phrases in the Book of Revelation, glosses that provide allegorical meanings related to morality. ${ }^{6}$

Concerning the Handbook's literary genre, Kenneth Steinhauser, who studied its relationship to Tyconius's Exposition of the Apocalypse, distinguishes the literary form of a commemoratorium or "handbook" from a commentarius or "commentary." He explains that this Handbook (Commemoratorium) on the Apocalypse is not a "completely developed commentary" but rather a "primitive reading guide to the book of the Apocalypse," a text which is "at the same time both a memory aid and a list."7 Similarly, Gryson refers to the Handbook as a type of memory aid and lecture guide in the form of a gloss. ${ }^{8}$ More recently Faith Wallis has called it "a kind of telegraphic reader's guide to the terminology and symbols of Revelation."

The text of the Apocalypse on which the Handbook is based appears to be a mixed text with variants of both African and European Old Latin versions. ${ }^{10}$ One very unusual reading is the number of the beast (Rev 13:18) as $666,000 .{ }^{11}$

\section{Hiberno-Latin Features}

Many who have studied the Handbook recognize Irish characteristics in it and identify it as a Hiberno-Latin text. ${ }^{12}$ Bischoff notices that the Handbook's interpretation of the ten days in Rev 2:10 as the ten senses of the soul and body corresponds with comments in an Irish Commentary on Luke and another Irish text. ${ }^{13}$ Robert McNally argues that the Handbook's comment on Rev 1:11 bears a relationship to a passage in the Irish Liber de numeris. ${ }^{14}$ Grazia Rapisarda, who edited the Handbook in 1967, leans toward Bischoff's view that the Handbook displays Irish features, as does Joseph Kelly, who catalogues it among early medieval Hiberno-Latin commentaries. ${ }^{15}$ Gryson notes that some of the biblical variants in the Handbook correspond with biblical readings in the Irish Book of Armagh and a manuscript of Bede's Exposition of the Apocalypse at Durham, which suggests a similar insular tradition. ${ }^{16}$

Other features confirming an Irish connection include the Handbook's distinction between historia and sensus (on 1:13, 4:4, 14:20, and 21:15) that appears in other early medieval Hiberno-Latin exegetical works and the Handbook's use of Pelagius (on 1:1). ${ }^{17}$ In addition, many of the comments in the Handbook are similar to those in the Hiberno-Latin Apocalypse commentary in the Reference Bible, which according to Gryson reflects a shared Irish milieu rather than direct dependence between the two. ${ }^{18}$ 


\section{Author}

Gryson suggests that the original text was anonymous. ${ }^{19}$ It seems likely that the author was an Irish bishop who created the Handbook to equip priests with their preaching duties, although an educated cleric without the status of a bishop could have been entrusted with the task. The original place of composition cannot be determined, but Kelly thinks that the work was "probably from a continental Irish circle." 20 We know with certainty that in the late eighth century and early ninth century the Handbook was being used and copied on the continent. ${ }^{21}$

\section{Date}

Steinhauser and Martine Dulaey date the Handbook to the beginning of the seventh century. ${ }^{22}$ More recent research on the Handbook has shown that the author of the Handbook used the writings of Gregory the Great (d. 604 ) and the Etymologies of Isidore. ${ }^{23}$ Since Isidore's book was completed about 630, the fourth decade of the seventh century would be the earliest date for the composition of the Handbook. Concerning its latest possible date, Ambrose Autpert mentions and cites the Handbook in the preface of his Apocalypse commentary written during the pontificate of Pope Paul I (757-67). ${ }^{24}$ Between the time of Isidore and Autpert lies well over a century, but many who have studied the text have attempted to be more specific in dating it. Kelly assigns it to the eighth century, McNally to the mid-eighth century, and Gryson to the second half of the seventh century. ${ }^{25}$

Rather than an eighth-century date, a late seventh-century assignment seems more congruent with some of the content in the Handbook. Arianism, an anti-Trinitarian belief that was found on the continent well into the seventh century, and persecution of Catholics in certain Ariancontrolled regions are portrayed as being in the past. According to the author, the Antichrist will revive Arianism and make a law that anyone who holds the correct faith of the Trinity cannot buy or sell (on 13:1417), and when this occurs a third of the church will fall away from the Trinitarian faith (on 8:7). The fact that the future Antichrist will revive the heresy indicates that from the author's viewpoint it had already been stamped out. The last Arian kings in Europe were Grimwald, king of the Lombards (ca. 662-71) and his son Garibald (ca. 671). Nevertheless, Arianism still seems fresh in the memory of the author of the Handbook. He is very concerned that people maintain faith in the Trinity (on 1:6, 4:8, 6:6, $8: 7,13: 17,22: 14)$ and frequently mentions powers and rulers adversarial 
to the correct faith (on $6: 8,16 ; 16: 20 ; 19: 17$ ), which suggests that they were a recent threat. ${ }^{26}$ Since the Antichrist will revive the Arian heresy, it does indicate that at the time of the authorship of the Handbook Arianism was extinguished, but in the recent past. All of this is suggestive of a date for its composition in the late seventh century.

Also supporting a seventh-century date more than an eighth-century date for its composition is the fact that the author of the Handbook did not use the Apocalypse commentary of Bede, which was written in the first or second decade of the eighth century. In summary, the Handbook was probably written sometime in the last quarter of the seventh century.

\section{Sources \& the Prologue}

The Handbook used the Apocalypse commentaries of Victorinus, Tyconius, and Primasius, sometimes quoting them verbatim. ${ }^{27}$ The author also used Jerome's On Hebrew Names, Gregory the Great's Homilies on the Gospels, and Isidore's Etymologies. ${ }^{28}$ The author probably did not have the sixth-century Apocalypse commentaries of Apringius of Beja or Caesarius of Arles. ${ }^{29}$ Nevertheless, where similarities between the Handbook and these commentaries, as well as the eighth century commentaries of Bede and the Reference Bible, ${ }^{30}$ were noticed, footnote references have been provided in the translation with "Cf." One ninth-century manuscript (Bamberg) of the Handbook contains a prologue, but after studying the Handbook's manuscript history, Gryson considers it to be inauthentic. ${ }^{31}$ His arguments are convincing, and for that reason the prologue is not included in the translation.

\section{Interpretations and Eschatology}

As a guide for preachers, the Handbook at several places gives interpretations that are meant to clear up questions or misunderstandings that a parishioner might have upon hearing the Apocalypse read in the liturgy. For example, why are the martyrs asking the Lord to judge their enemies (Rev 6:10) when the Lord taught his disciples to love their enemies (Matt 5:44)? The answer in the Handbook is that the martyrs do not desire their enemies to be judged but to amend themselves of their sins. Rev 22:11: One who is in filth, let him be filthy still could also be easily misunderstood. The Handbook explains that let him be filthy still was not to be read as a command but as simply declaring people's unfaithfulness.

There is a concern throughout the Handbook for orthodoxy, inclu- 
ding the doctrine of the Trinity, a proper theology of grace $(1: 4,17)$, and the perpetual virginity of Mary (5:9). Heretics are frequently mentioned. Philosophers are among the author's enemies (11:2), and anti-Jewish sentiments are to be found in comments on Rev 22:11, 15.

Concerning eschatology, Enoch and Elijah appear in the Last Times to issue the "seventh proclamation" $(11: 3,15)$. Antichrist, who will be born from the tribe of Dan (7:5-8), comes, is identified with the beast of 17:3, is called "death" (20:13), persecutes the saints (9:14), and kills Enoch and Elijah $(9: 15 ; 11: 6)$. He has ten kings under him $(12: 3 ; 13: 3$, 17), and he has many disciples and a great army $(9: 7,13: 18)$. The Lord descends from heaven for the Last Judgment $(1: 7 ; 6: 10,17 ; 11: 11 ; 22: 17)$, at which time the general resurrection and ascension of the saints takes place (11:11-12). The thousand-year reign is the present reign of the righteous all the way up to Judgment Day (20:4). The first resurrection is when the righteous leave their bodies and go to their rest (20:5). According to the author, they are heretics who interpret the thousand years corporally and think that the devil is bound at the end of the world instead of when Christ died (20:1; 20:3; $22: 18)$. After the judgment, the righteous inherit eternal life, where there is a diversity of rewards and where time is no longer calculated (6:11, 10:6).

There is no indication that the author believes the coming of the Antichrist or the end of the world is near. Many of the passages that might easily be interpreted in an eschatological manner are allegorized and pertain to the Incarnation of Christ and life in the church..$^{32}$ In Rev 6:12 the great earthquake represents people moving in and out of the faith; and the darkening of the sun and moon is the saints in persecution. The islands fleeing (6:14) are people tossed about by the fluctuations of the age. The fall of Babylon (14:8) happened when Christ first came into the world and believers fell from malice. The way prepared for the coming of the kings of the east (16:8) is the way prepared for those who enter the church by faith.

As stated above, the sources of many of the comments throughout the Handbook can be recognized, but some are unique in the exegetical tradition on the Apocalypse in the early Middle Ages. The silence for half an hour (8:1) represents the reign of Antichrist. On 11:4, the two olive trees standing in the presence of the lord of the earth are the two witnesses standing in the presence of the Antichrist, not the presence of God. The angel in 14:18 is Raphael. The number of the beast in $\operatorname{Rev} 13: 18$ is 666, 000, which may represent the number of the beast's army or the number of his disciples. Interestingly, the author of the Handbook relates that the interpretation of the number and name of the beast "is understood according 
to the Hebrew language," an interpretation which modern scholars have returned to. ${ }^{33}$ These unique interpretations and others contained in the Handbook may derive from early medieval Irish exegetical traditions.

In summary, the pseudo-Jerome Handbook on the Apocalypse of the Apostle John, probably from the last few decades of the seventh century, contains short allegorical interpretations of words and phrases in the Apocalypse and functioned as a guide for preachers. The Hiberno-Latin Handbook draws from the well-known patristic commentaries of Victorinus, Tyconius, and Primasius, but also exhibits interpretations that are unique in late antique and medieval exegesis of the Book of Revelation.

\section{Reference Bible, On the Mysteries of the Apocalypse of John}

The second translated text, On the Mysteries of the Apocalypse of John (De enigmatibus ex Apocalypsi Johannis), is found in the eighth century Reference Bible. The Reference Bible is a large anonymous Hiberno-Latin commentary on most of the Bible. ${ }^{34}$ In 2003 a critical edition by Roger Gryson of its commentary on the Apocalypse was published. ${ }^{35}$ The English translation here is based on Gryson's edition.

\section{Author}

Typical of Hiberno-Latin exegetical works, the Reference Bible is anonymous; ${ }^{36}$ however, its unity suggests one author or a team of writers working together. ${ }^{37}$ Its Apocalypse commentary, in comments on Rev 1:16, 6:6, $11: 1,11: 19$, and 22:18-19, shows that the author was familiar with monasteries and monastic life. These references suggest that the author was a person closely associated with monastic life, and probably a monk.

Gerard MacGinty notices the text has a "schoolroom air" about it, mentioning the Magister/Discipulus dialogue in part of its preface. ${ }^{38}$ Based on internal evidence MacGinty also concludes that the original text was based on lecture notes. ${ }^{39}$ In the Reference Bible's Apocalypse commentary, the words "to teach" (docere), "teacher" (doctor), and "teaching" (doctrina), in their varying forms, appear over fifty times. Four times in the Apocalypse commentary, the writer divides all of humanity into three classes: teachers, students, and those who are neither. ${ }^{40}$ On Rev 1:3 the author interprets the biblical phrase: Blessed is the one who reads as "blessed is the teacher who teaches."

Furthermore, the seven stars (1:16), the seven angels (8:2), the seven peals of thunder (10:3), the bridle of horses (14:20), the thigh of a 
horseman (19:16), and twelve thousand stadia (21:16) are all interpreted as teachers in the church. From these statements, it is almost certain that the author of the Reference Bible was a teacher.

\section{Date}

The Reference Bible was composed in the eighth century. The earliest manuscript with a portion of the Reference Bible, the Vatican manuscript, dates from about 800 or a little thereafter. ${ }^{41}$ This serves as its latest possible date. MacGinty, however, observes from three manuscripts (Munich, Paris, ${ }^{42}$ and the Vatican) that two recensions of the original commentary on Genesis already existed "by about 800 , at the latest," which moves the date of the original composition of the work earlier. ${ }^{43}$ Kelly assigns it to the late eighth century, ${ }^{44}$ and Martin McNamara in one place notes that it was composed between 750 and $800,{ }^{45}$ but leans toward the earlier of these two dates. ${ }^{46}$

MacGinty believes the Reference Bible derives from the first half of the eighth century because of the history of the text and because the complier did not use the works of Bede. ${ }^{47} \mathrm{He}$ dates the text even more precisely, "at about $730 \mathrm{AD}$ " or "in the 730 s," a timeframe he gained from a passage in the Paris manuscript preceding the text's title and not related formally to the main text. It reads: "Post passionum domini nostri Iesu Christi sunt anni plus minus[ue] septingenti" (After the passion of our Lord Jesus Christ there are more or less seven hundred years). ${ }^{48}$ The Reference Bible could not be much earlier than the 730 s, since a commentary on Matthew from Orléans, dated after $725,{ }^{49}$ was used as source material for it. In summary, the Reference Bible was composed in the eighth century sometime after 725 but before 800 .

\section{Irish Features and Place of Composition}

Irish features in the Reference Bible are many. They include: the use of the words pauca, problesmata, and enigmatibus in its title, ${ }^{50}$ which were favorite words used in titles of other known Hiberno-Latin works; ${ }^{51}$ its affinity with other early medieval Hiberno-Latin texts such as the pseudoIsidorian Liber de numeris, ${ }^{52}$ Collectanea of pseudo-Bede, ${ }^{53}$ and Catechesis Celtica ${ }^{54}$ its use of Latin phrases that are common in texts with an Irish background; $;^{55}$ and its citation of sources which, as McNamara notes, were "known to have been studied and used in the early Irish schools." 56

In the Reference Bible's Apocalypse commentary the Irish preoccu- 
pation with "first" things is present: ${ }^{57}$ in the preface to the Apocalypse commentary, the author tries to reconcile the diversity of opinions among the church fathers about whether John wrote his Gospel first or the Apocalypse first. ${ }^{58}$ Comments on Rev 1:16, 6:6, and 11:1 distinguish between the active and contemplative life (actualis/theoretica), a common feature of early medieval Hiberno-Latin exposition. ${ }^{59}$ The rendering of a particular word in the three sacred languages (Hebrew, Greek, and Latin), which Bischoff calls a "particularly favourite ornament of Irish erudition," ${ }^{\circ 0}$ appears in the explanation of the word "Amen" in Rev 1:6 and when the author names the king of the abyss in Rev 9:11. Its mention of ten senses, the five senses of the body and five senses of the soul, on Rev 2:10, is characteristically Irish; ${ }^{61}$ and the interpretation of the seven seals as seven events in the life of Christ was a preferred interpretation in Hiberno-Latin exegesis on the seals. ${ }^{62}$ The rejection of the concept of transmigration of souls on Rev 13:1, 13:12 probably reflects the author's concern with that belief which was still prevalent in Celtic regions. ${ }^{63}$ And a comment on Rev 1:14 about the Lord's eyes corresponds verbally with a comment on 1 Pet 3:12 in an Irish Commentary on the Catholic Epistles. ${ }^{64}$

Although the Reference Bible has Irish features, there is no clear indication within the text or in the manuscript tradition of where the original was written. The Paris manuscript was housed in Saint Germain des Prés and is presumably of French origin. ${ }^{65}$ The Munich manuscripts originated from St. Emmeram in Regensburg, and the Vatican manuscript was probably from the north of France. ${ }^{66}$ Therefore, it is entirely possible that the original was written at one of the Irish monastic centers on the continent. ${ }^{67}$ Thus Bischoff writes of an "Irish compiler of the late eighth century, who had possibly already worked on the Continent," ${ }^{68}$ while Kelly speaks of the Reference Bible as having been "compiled most likely in the late eighth century at an Irish center on the continent." ${ }^{\prime 9}$ MacGinty also concludes from a reference to the pagan Slavs that it derives from "an Irish or Irish-inspired centre" on the mainland of Europe. ${ }^{70}$

\section{Length and Purpose of the Apocalypse Commentary}

The Apocalypse commentary in the Reference Bible is long in comparison to the space the author devotes to commenting on the other canonical books. ${ }^{71}$ According to McNamara, this may reflect the compiler's interest in the Apocalypse or the number of sources on the Apocalypse that were available to him. ${ }^{72}$

After a short preface, the author usually proceeds by quoting several 
verses of the Book of Revelation and then goes back and comments on particular phrases. The biblical text used appears to be a version of Old Latin of the European grouping. ${ }^{73}$ The comments are often preceded by "that is" (id est) and are generally short, but sometimes two or more interpretations of a phrase are provided.

One of the aims of the Apocalypse commentary is to solve mysteries or problems generated by the canonical text. Most of these problems relate to when two statements in Revelation appear to contradict each other or when a statement in Revelation appears to contradict another passage of Scripture. The concordance of all Scripture is assumed by the author. One example of the text solving such problems is as follows. Rev 1:7 says that every eye will see Christ at his Second Coming, but Isa 26:10 claims that the ungodly will not see the glory of God. The solution is that at the Second Coming, every eye will see Christ in his flesh, but the Lord "will appear in the glory of his divinity only to the elect."

In the preface to the Apocalypse, the author says that there are "two levels of understanding" in the words of the Apocalypse. One of the author's goals is to provide the spiritual meaning (sensus or sensus spiritualis) "hidden by the literal" (istoria, historia, or littera). ${ }^{74}$ An example of the two levels of understanding is given at Rev 11:8, where the great city is called Sodom "according to history," but the spiritual meaning of the great city is the whole world whose evil deeds are similar to those of the residents of the historical Sodom. On Rev 11:11, the spirit of life indeed enters into the two dead witnesses "according to the historical sense," which points to the deeper meaning of the eschatological resurrection. Historically, the woman and the child in her womb in Rev 12 are Mary and Jesus, but the sensus is the church with Christ in her heart.

Often only the spiritual meaning of a word or phrase is given. This is usually allegorical or moral $;{ }^{75}$ for, according to the commentator, John himself was commanded to "write through allegory" (on Rev 10:4). Accordingly, the Son of God's eyes are the saints (2:18) and gold is the word of God (2:18). On Rev 6:1-5 the white horse represents Christians, the red horse persecutors, and the black horse heretics. The great mountain in Rev 8:8 and stone in 18:21 both represent the devil. The reed in Rev 11:1 and 21:15 is divine wisdom, and the two wings of an eagle (12:14) are the two testaments. The grievous wound in Rev 16:2 is sin in the soul, and the Euphrates River (Rev 16:12) symbolizes wicked people. 


\section{A Christocentric View of the Apocalypse}

For the author of the Reference Bible, the Book of Revelation is not primarily a revelation about history, whether a history of the church or a prophetic history of the last days; rather, it is a revelation about the person of Jesus Christ and his body the church. This guiding principle is shown from the very beginning of the commentary starting with the author's comment on Rev 1:1: "The things which are written in it (i.e., the Apocalypse) are about Christ and the church." One would expect in any Apocalypse commentary that interpretations of the visions of the Son of God in chapters 1, 4, 19, and 20 would relate to Jesus Christ, but for the author of the Reference Bible the entire book is about him. The door in heaven $(\operatorname{Rev} 4: 10)$ is Christ born in the church; and the book written inside and out (Rev 5:1) concerns his humanity and divinity. The opening of the seven seals (Rev 5-8) and the sounding of the seven trumpets (Rev 8-9) are revelations of seven major events in the life of Christ: his birth, baptism, passion, burial, resurrection, ascension, and future coming. ${ }^{76}$ In the visions of Rev 10 through Rev 20, almost every angel, even Michael the archangel, is interpreted as Christ himself. ${ }^{77}$ Similarly, the jasper stone (Rev 4:3, 21:18) represents Christ, and the ark of the covenant (Rev 12:1) is the flesh of Christ. Even the mark of the beast (Rev 13:18) is the chi-rho monogram of Christ altered by Christ's imposter, the Antichrist.

\section{Ecclesiology in the Apocalypse Commentary}

Since Christ is not without his body, the church, the visions of Revelation are also filled with symbols of the church. Heaven $(8: 1 ; 12: 1,8 ; 19: 11)$, thrones $(4: 2,4 ; 20: 4 ; 22: 1)$, the altar $(8: 3)$, the eagle $(8: 13)$, the temple $(15: 5,8)$, and the islands (16:20) all signify the church. Furthermore, the glassy sea in Rev 3:6 and 15:2 and the river in 22:1 are pictures of the church's sacrament of baptism; and the church's rulers are seen in the twelve angels of 21:12.

For the author of the Reference Bible, Revelation is not a blueprint of ecclesiastical history, revealing a succession of events from the Incarnation to the Second Coming. Such continuous-historical reading of the Apocalypse is explicitly rejected in a comment on Rev 9:13. The prophecy of the seven angels, the author writes, does in fact contain information about "the whole span of time from the birth of the Lord up to the end of the world." But while "some say that each of the angels would be in part of the world at one time, that they were ordered successively, and each 
one has been divided in his own time... we do not hold" such an opinion. Rather, the Book of Revelation concerns "the general matters" of the church (on Rev 1:1) such as its doctrine, practice, sacraments, and government. ${ }^{78}$ Regarding these matters, the commentator used Revelation to identify and promote Christian orthodoxy and conversely to warn his readers against heresy. Faith in the Trinity is affirmed in comments on 4:8; 6:6; and 21:13, and "orthodox" Christology — that he is God and man in one person-is promoted in comments on 6:6 and 19:12. The Apocalypse commentary also conveys Augustinian (or perhaps anti-Pelagian) teaching on grace. ${ }^{79}$

According to On the Mysteries, there is a "church of heresy" (on 9:13, $11: 2,16: 8$ ), a "body of heretics" (on 12:3), and "people of the heretics" (on 13:12). Heretics, symbolized by the locusts of Rev 10:3, kill souls, and anyone who consents to heretics suffers divine judgment "in the present and in the future" (on 8:10). Of specific heretics, only Arius is mentioned by name (2:7), but the faithful are warned not be corrupted by the heretical teaching of those who say that a person, after falling into sin, cannot be restored (on 2:5), ${ }^{80}$ of philosophers and astrologers (on 8:9), and of those who believe in reincarnation (on 13:1, 12). Also, anti-Jewish sentiments are present in comments on 1:11,3:7, 3:12, and 17:3.

The commentator also uses the Apocalypse for moral instruction, to encourage sanctification in the readers or hearers. Penance and compunction of the heart are common themes (on 4:1, 15:8, 20:5); and when John is told in 1:17 not to be afraid of the vision he just saw, the commentator used the lemma to instruct readers to "not be afraid to repent." The faithful should not be like those who "serve earthly things" (on 1:7), but rather, supplanting vices (on 22:14), they ought to follow the example of Christ (on 21:11). The mention of the rich and poor in Rev 2:17 becomes an opportunity for the commentator to encourage almsgiving; and bodily and spiritual chastity are reinforced in comments on $\operatorname{Rev} 2: 20$, 9:17, 15:6, and 21:24.

\section{Non-Apocalyptic Eschatology}

The Reference Bible's comment on Rev 1:1 acknowledges that some "future things are predicted" in the Book of Revelation. From various statements throughout the commentary, the author's schema of last things is as follows: near "the end of the world," 81 Enoch and Elijah will appear and have a following (on 7:4, 8:1, 11:3-14). They are eventually killed by the Antichrist (on 11:7), who will be a Jew from the tribe of Dan (on 7:4). He will be possessed and empowered by the devil, will pretend to be Christ, 
will institute a false sacrament similar to baptism, and will have a symbol or mark which mimics the chi-rho of the true Christ (on Rev 13). Part of every tribe and tongue and nation will believe in him and worship him. He will attempt to get Christians to deny Christ and will bring about a severe persecution (on 6:12, 9:1, 9:7, 9:13), even killing Christians (on 13:7). In the persecution a tenth part of the church will fall away from the faith of Christ (on 6:12-13, 11:13). His reign of terror will last three and a half years (on 9:15, 11:2, 11:7, 11:9, 17:9, 20:3). How he dies is not stated, but after his persecution has ended, but before Judgment Day, there will be a time of peace (on Rev 9:13, 11:3). ${ }^{82}$

At the Second Coming of Christ (on 1:7, 5:1), the elements will burn (on 5:1), and the living and the dead will be raised (1:15, 6:11, $11: 12$ ), at which time the righteous dead will add beatitude of body to the beatitude of soul which they already enjoy (on 6:11). Christ's purpose in coming again is to judge the world (on 6:11, 9:13, 13:5, 16:19, 16:21, 18:21-22). On Judgment Day the wicked and the devil will be cast into hell to suffer eternal torment (on 2:11, 3:14, 4:5, 8:7-8, 18:21, 20:13), and heathen people will be assigned a lower station in hell than others (on 6:8). The righteous will receive eternal life (on 2:5, 21:16), and heaven and earth will be recreated (on 20:11). Concerning the thousand years of Rev 20, Christ bound the devil at his passion (on 9:14), and he remains bound throughout the whole New Testament age, but will be loosed again in the time of Antichrist (on 20:2-3). The reign of the saints is the present reign of the church throughout the New Testament age (on Rev 20:4).

That the end of the world would come is a given, but when it will come is unknown. There is no indication that the author believed the end of the world was imminent, and he nowhere interprets current events as signs indicating the nearness of the coming of Antichrist, the Second Coming of Christ, or the end of the world. The earthquakes and radical changes in the sun and the moon in the biblical text (cf. Rev 6:12, 8:5, 9:2, $11: 13,11: 19,16: 8,16: 18$ ) are merely symbols of Christians being martyred, falling into heresy, or denying Christ in time of persecution. At one point in the discussion of the number of the beast, the author wrote that "Christ did not want to divulge clearly to human knowledge the day of judgment or of his coming, as he said to the apostles: It is not yours to know the times or seasons, etc. (Acts 1:7)." The author clearly did not want his readers to use the numbers in the Book of Revelation to predict the date of the end of the world. Even more telling is that every passage in Revelation that mentions the Lord coming quickly $(2: 5,2: 16,3: 11,22: 7,22: 12$, 
22:20) is not even quoted, much less commented upon. Such avoidance seems deliberate, as if the author were being especially careful to provide an interpretation of Revelation void of apocalyptic imminence.

\section{Sources}

The source cited most often in the Apocalypse commentary is a lost HibernoLatin Apocalypse commentary from the first half of the eighth century, which lies behind at least three texts: On the Mysteries, the Exposition on the Apocalypse of Theodulph of Orleans ${ }^{83}$ and the Cambridge Gloss on the Apocalypse. ${ }^{84}$ All three texts are not dependent on the two others; rather, all three are tributaries of the lost commentary. ${ }^{85}$ The dependence of the Reference Bible's Apocalypse commentary on this lost commentary can be gleaned from a comparison of its comments with those in the other two texts. Because the lost commentary has not yet been reconstructed, in the translation I have not put any quotation marks or footnotes to indicate where the Apocalypse commentary in the Reference Bible may have been quoting or paraphrasing the lost commentary.

Another main source for the Apocalypse commentary of the Reference Bible was Tyconius's Exposition of the Apocalypse. ${ }^{86}$ It may have been that the author of the Reference Bible did not have direct access to Tyconius, but that the Tyconian material in the Apocalypse commentary was transmitted indirectly through the lost commentary, which was heavily dependent upon Tyconius. ${ }^{87}$ Some quotations and allusions to Tyconius may have also found their way into On the Mysteries via Primasius. The footnotes in the translation which indicate that Tyconius is the source of a comment do not always list the intermediaries through which that comment may have come into the Reference Bible.

Primasius, the sixth-century North African bishop who wrote a Commentary on Revelation, is quoted directly at least five times and cited by name three times. ${ }^{88}$ The author quotes also from Isidore of Seville's Etymologies at least three times and cites Isidore by name four times. ${ }^{89}$ Jerome, whose Letters, Chronica, and On Illustrious Men are used, is cited by name in the preface. His On Hebrew Names is most likely the source behind the interpretations of names like Asia (1:4), Nicolaitans (2:7), Jezebel (2:20), Egypt (11:7), Babylon (14:8), Armageddon (16:16), and Gog and Magog (20:8), but they too could have come in through an intermediate source. ${ }^{90}$ In at least one place $(5: 1)$ a comment is dependent on Jerome's recension of the Commentary on the Apocalypse of Victorinus of Pettau. ${ }^{91}$

Comments on Rev 13:18 contain direct quotations from the 
anonymous late sixth- century or seventh-century Excerpta de monogram$m a .^{92}$ Works of Gregory the Great are quoted and paraphrased on 6:11, 19:10, 19:13, but probably through the seventh-century compilation by Paterius. $^{93}$

Concerning whether Bede's Apocalypse commentary was a source for the Apocalypse commentary, Kelly answered in the affirmative, citing the comment on Rev 8:10-11 as evidence. ${ }^{94}$ But McNamara showed that this comment, although corresponding somewhat with Bede, has closer verbal correspondence with the comment on the same passage in the Cambridge Gloss. This means it more likely came from the lost commentary than from Bede. ${ }^{95}$

The author of the Reference Bible probably did not have the pseudoJerome Handbook on the Apocalypse of the Apostle John. Nevertheless, in over forty places, similarity in words and content between the two texts exist. Rather than dependence of one upon another, a better explanation is that they both are products of the same early medieval Hiberno-Latin exegetical tradition. ${ }^{96}$ The translation lists these similarities in footnotes.

As mentioned above, the Apocalypse commentary often gives several interpretations of a word or phrase. In these lists of interpretations, some sources from the patristic tradition are identifiable, but others are not. The others probably derived either from the lost commentary, the author's own thought, or early medieval Irish exegetical traditions. ${ }^{97}$

The eighth-century anonymous Apocalypse commentary in the Reference Bible, most likely composed in an Irish monastic environment on the continent, answers difficult questions that arise from apparent contradictions with other Scripture passages, offers spiritual interpretations of Revelation's visions, and presents a Christocentric, non-apocalyptic reading that divorces Revelation from speculation about the date of doomsday. Furthermore, it synthesizes patristic interpretations and serves as a reference work by providing a variety of interpretations compiled both from the Fathers and Irish exegetical traditions. It also functions as a major witness and source of a lost Apocalypse commentary from the first half of the eighth century.

In the translation I have added chapter numbers and verses to match the chapters and verses in modern versions of the Book of Revelation. Biblical passages from Revelation and other biblical books are placed in italics; and I have used the modern enumeration of the Psalms. When for clarity I added a word that was not in the Latin text, I usually enclosed it 
in brackets. However, pronouns, possessive adjectives, and "to be" verbs that were added are not placed in brackets except when they appear in quotations of Scripture. In the footnotes of the translation, "Cf." indicates similarity, not necessarily dependence, of the Reference Bible on that text.

Finally, it is fitting to address the spiritual exegesis of these two early medieval interpreters of the Apocalypse, because it differs so greatly from our own. Modern commentaries on the Book of Revelation often focus on literary structures, grammatical expressions, and the historical context of the book. Consequently, the exegesis found in these early medieval commentaries may seem foreign. But spiritual exegesis of the Apocalypse was a way for these authors to steer clear of what they viewed as the dangers of a "carnal" reading of the Book of Revelation. In their opinion, a carnal, or literal reading could lead to chiliasm, an interpretation of the thousandyear reign of the saints in Rev 20:1-6 as a future earthly kingdom, ${ }^{98}$ or they could induce people to interpret numbers in Revelation in such a way that the date of the Second Coming can be predicted. ${ }^{99}$ Early medieval spiritual exegesis of the Apocalypse avoided these pitfalls, and in their place provided doctrinal instruction in harmony with the rest of Scripture and moral exhortation that encouraged holiness. Furthermore, early medieval commentators on the Apocalypse believed that their brand of exegesis was based upon the authority of the apostle John, whom they believed wrote allegorically, and upon the authority of Jerome, who said that there were several levels of meaning in the words of the Apocalypse. ${ }^{100}$

\section{NOTES}

${ }^{1}$ It exists in five ninth-century manuscripts and many other manuscripts from the twelfth through fifteenth centuries; Commentaria minora, 192.

${ }^{2}$ Commentaria minora, 159-229. Earlier editions of the Handbook include Incerti auctoris Commentarius in Apocalypsin, ed. Rapisarda; Ein Traktat zur Apokalypse ed. Hartung. Hartung's edition was based on only one ninth-century manuscript in Bamberg.

${ }^{3}$ Kelly, "Bede and the Irish Exegetical Tradition on the Apocalypse," at 395.

${ }^{4}$ The seven angels ( $\left.\operatorname{Rev} 8: 2 ; 15: 6\right)$ represent the order of preachers, and their seven trumpets (15:6), their preaching or proclamation. The sickle in 14:14 represents the preachers of the gospel, and the sound of the mill (18:22), the sound of preaching. The rainbow (10:1), fire (11:5), and golden reed (21:15) are all symbols for gospel preaching.

${ }^{5}$ Bischoff, "Wendepunkte in der Geschichte der lateinischen Exegese im Frühmittelalter." English translation by Fr. Colm O'Grady as "Turning Points in the History of Latin Exegesis in the Early Irish Church" [Hereafter= "Turning Points"]. The quotation above is from "Turning Points," 143.

${ }^{6}$ For example, the great wall $(21: 12)$ represents faith. The white stone (2:17), the temple (3:12), and the denarius (6:6) all signify eternal life. Robes and garments represent chastity $(3: 4,7: 9,15: 15,22: 14)$, but fire is a symbol of fornication (13:13). The great 
mountain (8:7) and great star $(8: 10,9: 1)$ are the devil, while locusts and horses represent heretics $(9: 3,7,17 ; 14: 20)$.

${ }^{7}$ Steinhauser, The Apocalypse Commentary of Tyconius, 103.

${ }^{8}$ Gryson, "Les commentaires patristiques latins de l'Apocalypse," at 334; and Commentaria minora, 161, 180.

${ }^{9}$ Bede: Commentary on Revelation, trans. Wallis, 21.

${ }^{10}$ Commentaria minora, 177.

${ }^{11}$ For other variants of the biblical texts, see the footnotes to the Handbook's comments on Rev 6:8; 7:4; and 15:2, 7 .

${ }^{12}$ One exception is Steinhauser ("Bemerkungen," at 239-42), who conjectures that the Handbook was composed by a student of Cassiodorus at the Viviarum in Italy. He bases this upon the facts that the preface in the Bamberg manuscript suggests that the Handbook was composed shortly after Primasius's Commentary on the Apocalypse, that the sources used for the Handbook were known to be in Cassiodorus's library at Viviarum, that some verbal correspondence exists between a statement in the Handbook and Cassiodorus's Psalms commentary, and that there are similarities in passages of the biblical text in the Handbook with those in Cassiodorus's Complexiones.

${ }^{13}$ Bischoff, "Turning Points," 143. See also similar comments in the Handbook on Rev 9:5 and 11:13.

${ }^{14}$ McNally, "Der irische Liber de numeris," 121-22, cited in MacNamara, "Irish Tradition of Biblical Exegesis, A.D. 550-800," at 41-42, 53 no. 66. MacNamara ("The Newly-Identified Cambridge Apocalypse Commentary," 215), however, does not seem convinced of the Handbook's Irish affiliations.

${ }^{15}$ Rapidsarda, "Per una storia dell'esegesi irlandese"; Kelly, "Catalogue (II)," at 433: "The work has Irish characteristics."

${ }^{16}$ Commentaria minora, 178, 182; Bedae presbyteri exposition Apocalypseos, ed. Gryson, 188-192; Gryson, "Les commentaries patristiques latins de l'Apocalypse," at 337.

${ }^{17}$ On the frequent use of Pelagius by early medieval Irish exegetes, see Kelly, "The Venerable Bede and Hiberno-Latin Exegesis," at 70; Kelly, "Pelagius, Pelagianism, and the Early Christian Irish."

${ }^{18}$ Commentaria minora, 182.

${ }^{19}$ Commentaria minora, 180.

${ }^{20}$ Kelly, "Catalogue (II)," 433.

${ }^{21}$ The Handbook was used by Ambrose Autpert in the late eighth century in the monastery of Saint Vincent in Samnium, Italy, and by Theodulph of Orleans at the monastery of Micy near Orleans in the early ninth century. Also, in the early ninth century the Handbook was copied in Bavaria and Regensburg. Cf. Commentaria minora, 163-64, 192.

${ }^{22}$ Steinhauser, "Bemerkungen," 242; Dulaey, Victorin de Poetovio premier exegete latin, $1: 359$.

${ }^{23}$ Commentaria minora, 179.

${ }^{24}$ Ambrose Autpert, Expositionis in Apocalypsin libri I-V, 13: "Quod tamen huic tantummodo Apocalypsi beatus Hieronymus adscribit, cuius opera in diuinis rebus tanta uigent auctoritate, ut aduersus ea nullus audeat muttire. Ita namque de illa dicit: Tres sunt uisiones, una coporalis, altera spiritalis, tertia intellectualis."

${ }^{25}$ Kelly, "The Venerable Bede and Hiberno-Latin Exegesis," 72; McNally cited in Kelly, “Catalogue (II)," 433; Commentaria minora, 182. 
${ }^{26}$ Also, with the principle established in the Handbook that a proud king can prefigure the Antichrist (on 13:1), a comment about the defeat of Antichrist's persecutors may be revealing. On Rev 12:6, where the earth helped the woman clothed with the sun by absorbing the river flowing from the mouth of the dragon, the Handbook interprets the earth as the kingdom of the Romans killing the persecutors belonging to Antichrist. The comment is intended to speak of future events, but it may be also reminiscent of the final overthrow of Arian kings by Roman Catholic monarchs.

${ }^{27}$ Victorinus of Pettau, Commentaries on the Apocalypse; Tyconius of Carthage, Expositio Apocalypseos; Primasius of Hadrumetum, Commentarius in Apocalypsin.

${ }^{28}$ Jerome, De nominibus Hebraicis; Gregory the Great, Homiliae in Evangelia; Isidore of Seville, Etymologiae. alypsin.

${ }^{29}$ Apringius of Beja, Tractatus in Apocalypsin; Caesarius of Arles, Explanatio in Apoc-

${ }^{30}$ Bede, Expositio Apocalypseos. For descriptions and dates of all of these early medieval commentaries, as well as the earlier ones of Victorinus and Tyconius, see Matter, "Apocalypse in Early Medieval Exegesis."

${ }^{31}$ Commentaria minora, 182-88. Gryson's reasons for concluding that the prologue was not part of the original are as follows: First, the copier of $E$ manuscript, which is upstream in the stemma codicum from the Bamberg manuscript containing the prologue, and the copier of $L$ manuscript, which is a brother (frère) of the Bamberg manuscript, both decided not to reproduce the prologue. The reason these copiers did not reproduce it was because they recognized that it was not original to the word, not because it was lengthy or uninteresting. Second, there is already a short incipit at the beginning of the Handbook proper, which would be redundant if the prologue with its incipit were authentic.

${ }^{32}$ This is congruent with the statement of Bernard McGinn (Calabrian Abbot, 87) that during the early Middle Ages, "the Apocalypse was not usually seen as an 'apocalyptic' book."

${ }^{33}$ Many modern scholars claim that the number of the beast is the sum of the numerical value of the Hebrew letters for Nero, nrwn qsr (Neron Kaiser). For bibliographical references and a scroll discovered at Qumran containing a similar spelling of Nero's name, see Gumerlock, "Nero Antichrist."

${ }^{34}$ It contains no treatment of Lamentations, Baruch, 2 Thessalonians, 2 Timothy, Titus, 2 John, and 3 John.

35 Commentaria minora, 231-95.

${ }^{36}$ On anonymity among early medieval Hiberno-Latin texts, see Bischoff, "Turning Points," 89; and Kelly, "The Venerable Bede and Hiberno-Latin Exegesis," 66.

${ }^{37}$ McNamara, "Plan and Source Analysis," at 86; MacGinty, "The Pentateuch of the Reference Bible," at 165, no. 9: "I am careful to qualify compiler with (s), although the final editor was probably a single individual."

${ }^{38}$ Reference Bible, ed. MacGinty (CCSM 173), ix. The preface here refers to the preface of the entire Reference Bible not the preface to the Apocalypse portion.

39 Reference Bible, ed. MacGinty, xi; MacGinty, "The Pentateuch of the Reference Bible," 165.

${ }^{40}$ On Rev 8:7, 12; 9:15; and 16:19.

${ }^{41}$ Vatican City, Biblioteca Apostolica Vaticana, MS Vat. Reg. lat. 76, fols. 1-106. Commentaria minora, 234; McNamara, "Plan and Source Analysis," 86. 
${ }^{42}$ Munich, Bayerische Staatsbibliothek, Clm 14276 and 14277; Paris, Bibliothèque nationale de France, MS lat. 11561, fols. 1v-217v.

${ }^{43}$ MacGinty, "The Pentateuch and the Reference Bible," 166.

${ }^{44}$ Kelly, "Catalogue (I)," at 552; Kelly, "Das Bibelwerk," at 113.

${ }^{45}$ McNamara, "General Introduction," Apocrypha Hiberniae I, ed. McNamara, 27.

${ }^{46}$ McNamara, "Plan and Source Analysis," 86: "ca. 750 with a number of copies made soon afterwards.”; McNamara, "The Newly-Identified Cambridge Apocalypse Commentary," 219: "a date c. 750 (if not earlier) seems indicated for the Reference bible."

${ }^{47}$ MacGinty, "The Pentateuch and the Reference Bible," 166.

${ }^{48}$ Reference Bible, ed. MacGinty, xii ; MacGinty, "The Pentateuch and the Reference Bible," 166.

${ }^{49}$ Bischoff, "Turning Points," 89. This is assuming that Bischoff's date of after 725 for the Commentary on Matthew is accurate.

${ }^{50}$ That is, the title of whole Reference Bible, which is Pauca problesmata de enigmatibus ex tomis canonicis.

${ }^{51}$ McNamara, "Plan and Source Analysis," 85; Bischoff, "Turning Points," 84.

${ }^{52}$ Dated about 780 from Salzburg; see Kelly, "Hiberno-Latin Study of the Gospel of Luke," 15.

${ }^{53}$ Collectanea Pseudo-Bedae, ed. and trans. Bayless and Lapidge.

${ }^{54}$ A tenth-century collection of material for homilies with Irish affiliations, edited in Wilmart, Analecta Reginensia, 29-112. A new edition of the Catechesis Celtica is being prepared by Dr. Jean Rittmueller. On the Reference Bible's links with Liber de numeris, Collectanea of pseudo-Bede, and Catechesis Celtica, see McNamara, "Plan and Source Analysis," 91, 112 .

55 Some of the common Latin phrases with an Irish background are listed in McNamara, "Sources and Affiliations of the Catechesis Celtica," at 188-90.

${ }^{56} \mathrm{McNamara}$, "Plan and Source Analysis," 111.

${ }^{57}$ Bischoff, "Turning Points," 102.

${ }^{58}$ For the commentator's preoccupation with first things, see also his comments on Rev 4:7.

${ }^{59}$ Commentaria minora, 238; Scriptores Hiberniae Minores, xii; McNamara, "Sources and Affiliations of the Catechesis Celtica," 190.

${ }^{60}$ Bischoff, "Turning Points," 85. On this Irish feature, see Scriptores Hiberniae Minores, viii, xii; McNally, "The 'Tres Linguae Sacrae"”; and McNamara, "Plan and Source Analysis," 104, 106.

${ }^{61}$ Bischoff, "Turning Points," 86 . The idea of ten senses seems to have derived from Origen's Homilies on Leviticus, homily 3, 65.

${ }^{62}$ The seven seals were interpreted as seven events in the life of Christ in the Catechesis Celtica. See The Seven Seals of the Apocalypse, ed. Gumerlock, 34-35; and McNamara, "The Affiliations and Origins of the Catechesis Celtica" at 199-200.

${ }^{63}$ For example, in the eighth-century Celtic tale 'Compert Con Culainn' in "Celts, Karma, and Reincarnation,” available online at http://www.summerlands.com/crossroads/ library/celts_and_karma.html. Accessed January 18, 2016.

${ }^{64}$ Commentarius in Epistolas Catholicas Scotti Anonymi in McNally, Scriptores Hiberniae Minores, 33.

${ }^{65}$ Commentaria minora, 234; McGinty, Reference Bible, xiv. 

86-87.

${ }^{66}$ Reference Bible, ed. MacGinty, xiii, xv-xvi; McNamara, "Plan and Source Analysis,"

${ }^{67}$ On Irish centers of learning on the continent in the early Middle Ages, see McNamara, "The Affiliations and Origins of the Catechesis Celtica," 182-83; Martin, "The Verona Homily Collection and Its Irish Connections," 25, 37; Doyle, "The Latin Bible in Ireland," 37; and Hughes, "The Distribution of Irish Scriptoria and Centres of Learning from 730 to $1111 . "$

${ }^{68}$ Bischoff, "Turning Points," 86.

${ }^{69}$ Kelly, "Catalogue (I)," 552.

${ }^{70}$ Reference Bible, ed. MacGinty, xii; MacGinty, "The Pentateuch of the Reference Bible," 167.

${ }^{71}$ McNamara, "The Newly-Identified Cambridge Apocalypse Commentary," 217.

${ }^{72}$ McNamara, "The Newly-Identified Cambridge Apocalypse Commentary," 217; Bede: Commentary on Revelation, trans. Wallis, 21: "The section devoted to Revelation is disproportionately large, testifying to the interest this book held in Irish scholarly circles."

${ }^{73}$ Commentaria minora, 238; McNamara, "The Newly-Identified Cambridge Apocalypse Commentary," 209-210.

${ }^{74}$ On Rev 2:17. On the distinction between historia and sensus in Hiberno-Latin exegetical texts, see McNamara, "The Irish Tradition of Biblical Exegesis," 42, and "Sources and Affiliations of the Catechesis Celtica," 189.

${ }^{75}$ On sensus comprising both the moral and the allegorical senses, see McNamara, "The Irish Tradition of Biblical Exegesis," 42.

${ }^{76}$ Reference Bible, On the Mysteries of the Apocalypse of John, on Rev 5:1 and 8:2.

${ }^{77}$ On Rev 10:1, 12:7, 14:15, 18:1, 18:21, 19:17, and 20:1.

${ }^{78}$ Here the author is quoting Primasius.

${ }^{79}$ Regarding anti-Pelagian teaching on grace, on Rev 4:1 the author writes that Job was able to not sin with his lips only because he was graciously enabled by God. And on 4:10 the elders' casting down of their crowns teaches that whatever good the saints possess, "they attribute everything to God." However, Pelagius is used as a source in the Reference Bible in the commentaries on the Pauline epistles. Kelly, "Das Bibelwerk," 119, 121.

${ }^{80}$ This resembles the teaching of rigorists such as the Novatianists and Donatists of early Christianity, who often refused readmission into the church of certain repentant sinners, such as murderers, adulterers, and those who denied Christ.

${ }^{81}$ On 9:13, 10:7, 11:9, 11:13, 12:14, 15:1, 16:14, 17:12.

${ }^{82}$ This time of peace in the last days is based on 1 Thess 5:3.

${ }^{83}$ Theodulph of Orleans, Expositio in Apocalypsin Johannis.

${ }^{84}$ Incerti Auctoris Glossa in Apocalypsin. On the lost commentary, see Tyconii Afri Expositio Apocalypseos, 64; Incerti Auctoris Glossa in Apocalypsin, 7-8; Commentaria minora, 182, 237-39, 300; McNamara, "The Newly-Identified Cambridge Apocalypse Commentary," 220.

${ }^{85}$ Tyconii Afri Expositio Apocalypseos, 64.

${ }^{86}$ Tyconii Afri. Expositio Apocalypseos.

${ }^{87}$ Commentaria minora, 239, 242.

${ }^{88}$ On Rev 1:1, 6:6, 7:4, and 13:18. Primasius of Hadrumetum, Commentarius in Apocalypsin.

${ }^{89}$ In the preface (where Isidore's Chronicle is alluded to) and on $\operatorname{Rev} 1: 8,6: 6$, and 13:18. 
${ }^{90}$ Jerome, De nominibus Hebraicis.

${ }^{91}$ Victorinus of Pettau, Commentaries on the Apocalypse. On Jerome's recension of Victorinus, see Matter, "Apocalypse in Early Medieval Exegesis," 38-40.

${ }^{92}$ Edited in Commentaria minora, 131-57.

${ }^{93}$ Paterius, De testimoniis.

${ }^{94}$ Kelly, "Bede and the Irish Exegetical Tradition on the Apocalypse," 397-98.

${ }^{95}$ McNamara, "The Newly-Identified Cambridge Apocalypse Commentary," 218, no. 49. The few similarities between the Apocalypse commentaries in the Reference Bible and Bede can be accounted for by the fact that they both shared eighth-century insular exegetical traditions. On a common insular exegetical tradition, see Kelly, "The Venerable Bede and Hiberno-Latin Exegesis," 70, 72.

${ }^{96}$ Commentaria minora, 182.

${ }^{97}$ MacGinty, "The Pentateuch of the Reference Bible," 163; Kelly, "Das Bibelwerk," 121 and "Catalogue (I)," 552.

${ }^{98}$ See the comments in the Handbook on Rev 20:3 and 22:18.

${ }^{99}$ See the comments in On the Mysteries on Rev 13:18.

${ }^{100}$ See the comments in On the Mysteries in its preface and on Rev 10:4. 


\title{
Pseudo-Jerome Handbook on the Apocalypse of the Apostle John
}

\author{
Here begins the \\ Handbook on the Apocalypse of the Apostle John.
}

John is interpreted "grace of Christ." He kept the example of Christ. Sometimes when the Holy Spirit speaks about his servants through them, he speaks as if about others, just as John did here. ${ }^{2}$ There are three kinds of visions: one carnal, another spiritual, and a third intellectual. Truly this is an intellectual vision which is more sublime than the others. ${ }^{3}$

\section{Chapter 1}

1 Apocalypse "is interpreted as Revelation." ${ }^{4}$ Revelation of Jesus Christ, which God gave to him. Here the Trinity is understood: Christ the Son of God, God the Father, and the Holy Spirit is speaking through John. To make plain, that is, to show to his servants, that is, to believers in Christ, the things which must happen, that is, what is contained in this revelation, shortly, before the death of each person, or the Day of Judgment, comes. He signified, that is, sealed. God the Father sending through his angel, that is, Christ, since he is the angel of great counsel, ${ }^{5}$ to his servant John, [a servant] "not of sin," ${ }^{6}$ but of a good will.

2 Who bore witness, that is: In the beginning was the Word, etc. (John 1:1). ${ }^{7}$ And testimony of Jesus, that is, of the Incarnation, just as John himself said: There are three who bear witness, that is, the water and the blood and the Spirit (1 John 5:7-8). Whatever he saw, either concerning his glory or concerning the Incarnation.

3 Blessed is the one who reads and those who hear the words of this prophecy. Unless it is read first, it is not able to be heard. And keep the things which have been written in them, those who fulfill it in deeds. For the time is near, that is, either for each person, or the Day of Judgment.

4 Asia is interpreted "elevation." Elevation is understood in two ways: either concerning the righteous on account of their good works, 
or concerning sinners on account of their evil works. John wrote to seven churches because he had a portion of each of the seven gifts of the Holy Spirit. ${ }^{9}$ The seven churches contain a figure of all the saints. One of those churches does not have sin, as revealed by the consolation [given to it]. Or [he wrote to seven churches] because the world runs its course through seven days, ${ }^{10}$ and the church is under the seven gifts of the Holy Spirit. Grace to you and peace from God. There cannot be peace unless grace precedes. Grace is understood in three ways, that is, baptism, penance, and perseverance. Who is, who always is. Who was, [who] in the present is in the flesh. Who is to come, that is, for the judgment. ${ }^{11}$

And from the seven spirits who are before his throne, $\mathbf{5}$ and from Jesus Christ. Here also the Trinity is understood. Who is the faithful witness, because through his death he ratified ${ }^{12}$ the new testament (a testament is not valid until after a person's death ${ }^{13}$ ), and because he bore witness of the resurrection of the dead, demonstrating it first in himself. The firstborn of the dead, because "He arose as first from the dead." ${ }^{14}$ And Prince of the kings of the earth, of the apostles and of all of the saints. Who loved us, etc., when he redeemed the human race.

6 And made us a kingdom of priests. Before Christ was born, priests were from one tribe, but after Christ came into the world, he made us all kings and priests. ${ }^{15}$ For God and his Father. Here also the Trinity is shown. For God, for Christ; for the Father, for God the Father, and the Holy Spirit is speaking. To him be glory. The [divine] unity is understood. Forever and ever, because he has neither beginning nor end. ${ }^{16}$

7 Behold he comes with clouds, because with a cloud he ascended to heaven with angels, ${ }^{17}$ and with a cloud or with the powers of heaven ${ }^{18}$ he will descend for the judgment. And every eye will see him, that is, on the Day of Judgment, even those who pierced him. And all the tribes of the earth will mourn, that is, the Jews or those who denied Christ. Amen, "truly or faithfully." 19

8 Omnipotent since he conquered the devil and freed the human race; devil is interpreted as "flowing down." 20

9 I, John, your brother, spiritual [brother]. Brothers are understood in four ways: by nature, by relationship, by affection, and by adoption. ${ }^{21}$ In tribulation, in persecution, and the kingdom in the future, and patience in Jesus. Unless one has patience, he is not able through tribulation to enter the kingdom of God (Acts 14:22). Island. Because the sea surrounds it, it signifies tribulation.

10 I was in the Spirit, in the grace of the Holy Spirit, on the Lord's 
day, in the new covenant ${ }^{22}$ because neither the darkness of ignorance nor the power of the devil are there. It is called the Lord's day because of the resurrection. Heard behind me a great voice, [great] because it told of great things, that is, about the passion, about the resurrection, and the Day of Judgment. Here John is ${ }^{23}$ a figure of the human race.

As of a trumpet 11 saying to me. Through the trumpet is understood preaching, and each preacher is called a trumpet. ${ }^{24}$ Write in a book, in his heart ${ }^{25}$ so that it would not be forgotten. Ephesus is interpreted "will" or "my counsel," Smyrna "their song," Pergamum "dividing their horns," Thyatira "illuminated," Sardis "first in beauty," Philadelphia "preserving an inheritance for the Lord," Laodicea "tribe beloved to the Lord.".

12 And I turned to see the voice, converted to good work. Vision is more sublime than hearing. He saw not with carnal but spiritual eyes. The seven golden candlesticks are understood as the seven churches, which are under the seven gifts of the Holy Spirit. ${ }^{27}$ The candlestick is understood as each preacher.

13 In the midst of the seven candlesticks, because Christ is among all the saints. Like the Son of Man because he put on mortality. Clothed (Lat. podere). [A poderis] is a priestly garment. ${ }^{28}$ The clothing of Christ is understood as spiritual priests. And girt about the breasts because neither before the beginning of the world nor after its end is his power known, but only in the intervening time. Through the breasts is understood spiritual teaching. Through the golden girdle is understood chastity and the spiritual understanding.

14 His head is God the Father. ${ }^{29}$ Hairs, the saints or the virtues of the saints. Because they are white, they signify chastity. Through wool is understood charity, through snow, chastity, because it does not have the heat of vices. Eyes, the apostles or preachers, as a flame of fire because they were ignited by the Holy Spirit.

15 Feet, the apostles or holy preachers..$^{30}$ Through fine brass is understood fortitude. In a burning furnace, in tribulation. His voice as the sound of many waters is understood as the abundance of his teaching.

16 Here right hand is the future life. The seven stars are the angels of the seven churches. And from his mouth proceeded a sharp two-edged sword, the word of God $^{31}$ which ${ }^{32}$ judges concerning the soul and body. ${ }^{33}$ His face as the sun. The saints are understood..$^{34}$

17 He placed his right hand upon me. This is the help of Christ. 


\section{Chapter 2}

1 The One, who holds the stars in his right hand, in eternal life, says these things, who walks in the midst of them, that they might fear more.

6 Nicolas is interpreted as "fool of the fainting ${ }^{35}$ church." 36

7 The tree of life is Christ. ${ }^{37}$

10 Ten days is understood as the whole life of a person; through ten is understood the senses of the body and soul. ${ }^{38}$

12 The sword, the word of God.

14 Balaam is interpreted as "vain people," Balak "casting down." 39

17 Hidden manna, the word of God in the future. The white stone, on which the names of the saints are written, is eternal life.

20 Jezebel [is interpreted] as "a flow of blood" or "a flowing [of blood]," but better "dunghill." 40

28 The morning star, the resurrection. ${ }^{41}$

\section{Chapter 3}

4 They walked in white, in chastity.

7 Holy and true, holy by nature; true because he alone is true, ${ }^{42}$ who holds the key of David, that is, wisdom, who opens and no one shuts, that is, [opens] paradise and shuts hell. No one opens [hell] except one who commits sins.

8 Open door, the kingdom of heaven. Moderate strength, humility.

12 Pillars are understood as holy people. ${ }^{43}$ In the temple of God, in eternal life.

15 Cold in sin; hot, fervent in love. ${ }^{44}$

16 Lukewarm, neither bad nor good.

17 Wretched from his sins; miserable before God..$^{45}$ Poor in virtues. Blind of the light of knowledge. Naked of the faith of the Trinity.

18 Gold tried by fire, the understanding tested; in white garments, chastity and faith; nudity is unfaithfulness; eye salve, the word of God;46 eyes, the understanding of the mind.

20 God knocks in three ways: through compunction of the heart, through preaching, and through tribulation.

\section{Chapter 4}

1 Open door in heaven, faith in the church. And the first voice, that is, in that vision. Come up here, not from one place to another, ${ }^{47}$ but [ascend] in understanding and faith. 
After these things 2 I was in the spirit, in a spiritual vision, and behold a throne had been set up in heaven, the throne of God in the church, and upon the throne Christ was sitting.

3 Jasper has a color like the sea, sardonyx like blood. Through jasper is understood baptism, through sardonyx, martyrdom. The rainbow is in heaven. The New Testament is understood where there are three colors: water and sulfur and fire. Through water, baptism is understood; through sulfur, penance; and through fire, martyrdom. ${ }^{48}$ Water came in the flood, sulfur upon Sodom, and fire is going to come at the judgment. The rainbow around the throne is the gospel around the church. Emerald has two colors similar to water and fire. It signifies baptism and martyrdom.

4 Twenty-four elders. Twenty signifies the Decalogue doubled; four signifies the four Gospels. And according to a historical understanding, the seven patriarchs: Noah, Abraham, Isaac, Jacob, Moses, Aaron, and Joshua, and the twelve minor prophets: Isaiah, Jeremiah, Ezekiel, Daniel, and either Samuel or David. And on their heads golden crowns, that is, in the forefront of their minds future rewards.

5 And from the throne proceeds lightning. From the church [proceeds] miracles, voices, preaching ${ }^{49}$; peals of thunder, threatening. ${ }^{50}$

6 Sea of glass, baptism. ${ }^{51}$ In the midst of the throne, "in the midst of the church." ${ }^{52}$ Four living creatures, "the four Gospels." ${ }^{33}$ Full of eyes in front [showing] how they fulfill [the prophecies of the Old Testament], ${ }^{54}$ and behind, mindful of their sins. Again in another sense, full of eyes in front because they preach about the future judgment, behind because they give testimony about the Old Testament. Again in another sense, through the four living creatures are understood the four seasons of the year through which the world runs.

8 They have six wings because they preach the gospel through the six ages ${ }^{55}$ of the world, or they announce the six laws of the Old and New Testament, that is, the law of nature, the law of the letter, and the law of the prophets, the law of the gospel, the law of the apostles, and ecclesiastical law. They have eyes inside and out because they illuminate the church inside and out. And they had no rest day and night, that is, "in prosperity and adversity," ${ }^{56}$ saying: Holy, holy, holy. Here Trinity and unity are understood. 57

9 They gave glory, [the glory] of the resurrection; ${ }^{58}$ honor [the honor] of the ascension; blessing to him whom every creature blesses.

10 And they cast their crowns, that is, their praiseworthy qualities and virtues after the devil was defeated. 


\section{Chapter 5}

1 On a book written is understood the entire Holy Scripture. Inside, the spiritual meaning, and out, because it feeds souls according to its historical meaning. Sealed with seven seals, that is, the seven gifts of the Holy Spirit. ${ }^{59}$

2 And I saw an angel. This was an angel of any kind. ${ }^{60}$

3 And no one was able to open or to look into it because they were not able to understand it.

7 And he took the book when he took on flesh, as if he had received a book from the Father.

9 From every tribe of the twelve tribes, and language, from all languages, and people, the people of the Jews, and nation, from the Gentiles.

11 Thousands of thousands, that is, an innumerable multitude. ${ }^{61}$

12 And power, after he conquered the devil, and riches, after he ascended into heaven according to his assumed flesh.

13 And every creature which is in heaven, that is, the nine orders of angels and the ten orders of saints. ${ }^{62}$ And on earth, he speaks about the inhabitants of the earth. And under the earth, [he speaks] about the inhabitants of hell.

\section{Chapter 6}

1 Through the seven seals are understood seven proclamations. ${ }^{63}$

Come $\mathbf{2}$ and see: Here John is a picture of the human race, as if it is spoken to the human race. The white horse is understood to be the body of Christ. ${ }^{64}$ The one who sat upon it, that is, majesty in the body, had a bow, preaching. And a crown was given to him. A crown will not be given except after a victory.

4 The red horse contains a figure of the martyrs; the one who sat upon it, Christ; a great sword, the word of God. ${ }^{65}$

5 Through the black horse persecutors are understood. The one who sat upon it, that is, the devil. ${ }^{66} \mathrm{~A}$ scale in his hand because he does not tempt except when he is permitted by God. ${ }^{67}$

6 A quart is two pints. ${ }^{68}$ They signfy the Old and New Testament. Denarius is understood as eternal life; three quarts, the faith of the Trinity. ${ }^{69}$ Do not harm the wine and oil, those who are strong in faith and those who have mercy and spiritual anointing.

8 Through the pale horse hypocrites are understood. And hell followed him, that is, sinners; over the four parts ${ }^{70}$ of the earth, over those who are earthly minded in the world. Here the sword is fornication. With 
famine, that is, [a lack] of the word of God; ${ }^{71}$ and with death, that is, with the second death (Rev $2: 11 ; 20: 6,14 ; 21: 8)$; with the beasts of the earth, by adversarial powers.

10 How long, Lord, do you not judge?, etc. It is not that they are desirous of [their judgment], but desire that they may amend themselves from sins or that Judgment Day would come quickly so that they may sin less. ${ }^{72}$

11 Robes to each, eternal life, ${ }^{73}$ but among them there is a diversity of merits. $^{74}$

12 A great earthquake occurred. Some [moved] into the faith; others [moved] outside the faith. ${ }^{75}$ The sun became black, the saints in persecution. The moon as blood, similarly the saints.

13 The stars will fall from heaven. Souls [will fall] from the church.

14 Heaven receded, that is, the saints; mountains, similarly the saints are understood; islands, those who have tribulations. Again in another sense mountains, sinners, and islands, those who are [tossed about] by the fluctuations of the age.

15 The kings of the earth, saints or sinners; princes, their subjects; and tribunes, according to their grades in evil, and the rich, those who are [rich] in sins, and the strong, that is, [strong] in evil, every servant, those who are enslaved in sin, and free person who is outside the bond of servitude to God; ${ }^{76}$ hid themselves in the caves, in their consciences, and rocks is understood as their hardness.

16 Say to the mountains, to adversarial powers.

17 Because the great day is coming, the Day of Judgment. Who will be able to stand except one who is righteous?

\section{Chapter 7}

1 These four angels. Each of the angels ${ }^{77}$ who have dominion in the world were [seen]. Four corners of the earth, the four Gospels. Four winds, the four proclamations of the Gospels. That the wind should not blow upon the earth, that there should be no preaching upon the church, nor upon the sea, upon the heathen, nor on any tree, on no human.

2 This is Christ, the angel of great counsel (Isa 9:6 LXX)..$^{78}$ From the east, from the Father. Having the seal of the living God, that is, the cross. ${ }^{79}$

4 I saw ${ }^{80}$ the number of the sealed, one hundred and forty-four thousand. Through a hundred is understood every rational creature; through forty, the order of the penitent; through four, the four Gospels. This is a perfect number. It signifies the multitude of all the martyrs who are going to suffer.$^{81}$ From every tribe of the sons of Israel, from all the confessors. 
5-8 The tribe of Judah, because Christ was born from that tribe; for that reason it was placed first. ${ }^{82}$ He put twelve thousand from each tribe because of the number of the twelve apostles, not because there may be such a small number of the righteous. Here the tribe of Dan is not placed in the number because the Antichrist is born from that tribe. ${ }^{83}$

9 Clothed in white robes. Chastity is understood or the bodies of the saints. Palm branches in their hands, that is, rewards. ${ }^{84}$

11 They fell before the throne. Their humility and his dignity are shown.

12 Blessing. Every creature ${ }^{85}$ blesses him. Glory of the resurrection. All these things ${ }^{86}$ pertain in particular to the praise of Christ.

13 One of the elders, whichever of them. John is asked this so that [the elder] may be taught.

16 Neither will the sun beat down upon them. Here the sun is understood as tribulation. Nor any heat, no adversity of the flesh.

17 And he will lead them to the springs of the waters of life, that is, to the Father. And God will wipe away every tear from their eyes. When he says every, he shows that the saints mourn not only for their own sins but also for the sins of others.

\section{Chapter 8}

1 When he had opened the seventh seal, the seventh proclamation, there was silence in heaven, because no one was going to preach in the church, for half an hour, because of the reign of Antichrist, since it is an imperfect number. From here there is recapitulation. ${ }^{87}$

2 The seven angels are understood as the order of preachers, [who preach] through the seven gifts of the Holy Spirit. ${ }^{88}$ The seven trumpets are their proclamations.

3 Another angel is understood as Christ. Golden censer, his body. Much incense, the prayers of the saints. ${ }^{89}$

5 Filled it from the fire of the altar, from majesty. ${ }^{90}$ Cast [it] upon the earth, when he was born from Mary.

7 This first angel is the first proclamation through the apostles. Hail and fire mixed with blood, the persecution of the apostles, and likewise the persecutors. Through hail they experienced the coldness of unbelief, and through fire the heat of persecution. It also signifies the punishments of those [unbelievers and persecutors] in the future. Was cast upon the earth, upon the church. When he says a third part, he shows those who fall away from the faith of the Trinity, since both that which is numbered and that which remained is an imperfect number. Third part of the earth, those 
who were perfect; third part of the trees, those who are less with regard to perfection..$^{91}$

8 Second angel, the second proclamation. Great mountain, the devil..$^{22}$ Was cast into the sea, into all nations. A third part [was turned into] blood, into unbelief.

9 A third part of the earth, of the human race; a third part of the ships, that is, [a third part] of the churches.

10 Third angel, the third proclamation. A great star fell from heaven,

the devil. Fell upon a third part of the rivers, the persecutors; the springs of the waters, those who are less with respect to malice.

12 Fourth angel, the fourth proclamation. The sun and moon and stars represent the diversity of believers. ${ }^{93}$ So that a third part of them would be darkened, those who fall away. The day, believers; night, those who are in $\sin { }^{94}$

\section{Chapter 9}

1 Fifth angel, the fifth proclamation. A great star, the devil. The key to the bottomless pit was given to him, the key to hell.

2 He opened the bottomless pit, because through his deception sinners enter there. Here smoke is understood as ignorance, the sun as the church, and the air as those who are heavenly in conduct.

3 Locusts came forth onto the earth, that is, heretics. ${ }^{95}$ Scorpions, demons.

4 Grass, those who begin to believe.

5 Five months, those who are given unto worldly desires through the five senses ${ }^{96}$ of the body.

7 Locusts, heretics. Or the disciples of Antichrist.

8 Through their hair the will ${ }^{97}$ is understood. And their teeth like those of lions, because in this manner they will be strong ${ }^{98}$ in evil.

9 Breastplates, their hardness. ${ }^{99}$ Wings, their teaching. Their sound [is] like the sound of chariots, because they will be joined together in evil. Horse, because of their excess. ${ }^{100}$

10 Their tails, perseverance in malice. Their sting is sin.

13 Sixth angel, the sixth proclamation.

14 The four angels are the four evangelists. Great river Euphrates, the persecution of Antichrist.

15 For the hour, day, year, and month signifies the reign of Antichrist. ${ }^{101}$ That they should kill a third part of humanity, spiritually speaking, Elijah and Enoch.

17 I saw horses, that is, heretics. Those who were sitting upon them, 
demons. ${ }^{102}$ Having breastplates of fire and of hyacinth and of brimstone signifies punishments.

19 Their power is in their mouth, in their excess and sin. And in their tails. [Their tails] are understood as those who succeed them.

\section{Chapter 10}

1 That angel is understood as Christ. ${ }^{103}$ Clothed with a cloud when he took on flesh. ${ }^{104} A$ rainbow on his head, the preaching of the gospel. Face, majesty. Feet, the apostles. ${ }^{105}$

2 He had in his hand an open book, that is, the holy Scripture. Right foot, the apostles. Or those who are strong ${ }^{106}$ in preaching. Left foot, those who are weaker ${ }^{107}$ in the church.

3 Seven peals of thunder, the seven gifts of the Holy Spirit ${ }^{108}$ when he opened the Scripture.

4 Seal up and do not write them down, because before Christ came, they were sealed, that is, obscure.

$\mathbf{6}$ He swore that time will be no more because afterward times will not be calculated.

8 Here John is a figure of the human race. That book is understood as the entire Holy Scripture. ${ }^{109}$

9 Take and eat it, that is, that all things whatsoever that have been commanded may be fulfilled in deed. ${ }^{110}$ Here stomach is understood as the will; ${ }^{111}$ bitter when it is preached that we must leave behind all things for the sake of Christ ${ }^{12}$; sweet when eternal life is promised.

11 You must prophesy again, ${ }^{113}$ fulfill in deed.

\section{Chapter 11}

1 Here John is a figure of all of the saints or of preachers. There was given to me a reed, the preaching of the gospel, similar to a rod, to a likeness of the preaching of Christ. Measure the temple of God for each one according to his own measure ${ }^{114}$ to preach in the church. And the altar, faith.

2 The courtyard which is outside the temple, heretics and philosophers and heathens who are outside the church. The holy city, the church. ${ }^{115}$ Fortytwo months, that is, the time of Antichrist. ${ }^{116}$

3 Two witnesses, Elijah and Enoch.

4 Through the olive trees is understood spiritual unction, through the candlesticks preaching. In the presence of the lord of the earth, in the presence of Antichrist. 
5 Fire, preaching.

6 Having power over the waters, over people. Of turning them into blood through martyrdom. To strike them with every plague, both spiritually and bodily.

8 Here the great city is understood as the world. ${ }^{117}$

11 After three and a half days the spirit of life entered into them, that is, on Judgment Day.

12 When he says: Come up here it is a figure of [the ascension of] all of the saints.

13 The tenth part of the city fell, that is, those who have been unfaithful through the ten senses of their body and soul. They gave glory to God, those who remained in faith [did this].

15 The seventh angel, the seventh proclamation under Elijah and Enoch. Voices in heaven, in the church.

19 Ark of the covenant in heaven, the heavenly Jerusalem, that is, the souls of the saints. ${ }^{18}$ Hail, persecution.

\section{Chapter 12}

1 A woman clothed, "the church." 119 Moon, those who are weaker since they wax and wane. ${ }^{120} A$ crown of twelve stars, the teaching of the twelve apostles ${ }^{121}$ in the beginning of the church.

2 Having [a child] in the womb, [having] Christ in her heart. ${ }^{122}$ Giving birth to some in faith. She is tormented by persecutors.

3 Red dragon, the devil, ${ }^{123}$ [red] through the shedding of the blood ${ }^{124}$ of Christ or of the saints. Having seven heads, in contrast to the seven gifts of the Holy Spirit. ${ }^{125}$ Ten horns, ten kings under Antichrist. ${ }^{126}$ On [their] heads seven diadems, iniquity.

4 Tail of the devil, the Antichrist. Just as he dragged down a third part of the angels, so also he dragged down a multitude of unbelievers. Cast them onto the earth, into their unbelief. About to give birth. It is the church [about to give birth to] a people for God.

5 In the way that Mary gave birth to Christ, so the church gives birth to Christian people.

6 Wilderness is understood spiritually as heaven.

14 Two wings were given to the woman, the two laws ${ }^{127}$ or the two commandments of love. ${ }^{128}$

16 Here earth is understood as the kingdom of the Romans. It absorbed the river. They [i.e., the Romans] killed the persecutors belonging to Antichrist. ${ }^{129}$ 


\section{Chapter 13}

1 He stood upon the sand of the sea, over sinners. That beast, a king who will be first, ${ }^{130}$ in the manner of Antichrist.

2 That beast similar to a leopard is understood as the variety of heretics. Feet like those of a bear because of his strength.

3 One of the heads, one of ten kings, as if slain, because in his place another will enter.

11 And I saw another beast, as it were, a third king, a servant of Antichrist. Had two horns, two kingdoms. Similar to a lamb, as if in a likeness of Christ. And spoke as a dragon, as Antichrist.

13 So that he even made fire come down from heaven. Fire, fornication in sinners.

14 Saying to those who dwell on earth that they should make an image of the beast, that is, an image of that heresy which will have been before him.

15 And the image of the beast spoke, since that heresy had been revived through him. ${ }^{131}$

$16 \mathrm{~A}$ mark on their right hand or on their foreheads, [marked] by their evil deeds.

17 That no one, that is, the saints who rightly held the faith of the Trinity, is able to buy or sell except one who has the mark of his name.

The number of his name. The seven evil spirits against the seven gifts of the Holy Spirit, or the ten kings against the ten commandments of the law.

18 For it is the number of a man, and his number is six hundred and sixty-six thousand because he pretends to keep the law throughout the week. ${ }^{132} \mathrm{Or}$, the number of his name is understood according to the Hebrew language. Or the number of his army. Or the number of his disciples.

\section{Chapter 14}

6 Recapitulation. ${ }^{133}$ I saw an angel flying through the midst of heaven. Here the angel is Christ. Through the midst of heaven, through the church. ${ }^{134}$

8 Another angel, the first proclamation. ${ }^{135}$ Babylon is understood as the world. ${ }^{136}$ Has fallen from malice when Christ came into the world. From the wine of her fornication, from idolatry.

9 And another angel, another proclamation. ${ }^{137}$

10 Mixed undiluted because he has mercy on those who are repentant and shows severity in judgment to those who are negligent.

14 And I saw a white cloud. This cloud is understood as the body of Christ, ${ }^{138}$ the golden crown his divinity. And in his hand a sharp sickle, the preaching of the gospel. 
15 And another angel, another proclamation.

18 Another angel who has authority over the fire, the order of preachers or Raphael. ${ }^{139}$ Cluster of the vine, that is, a ripened ${ }^{140}$ [cluster].

20 The winepress was trodden outside the city. According to a historical interpretation, when Christ suffered; according to the [spiritual] sense, sinners who will be trodden "outside the church." 141 Up to the bridles of horses, heretics, who are the bridles of sinners. For [a distance of] one thousand sixty stadia, the magnitude of the judgment.

\section{Chapter 15}

1 Seven angels, seven orders of preachers from the heretics.

2 The glassy sea signifies baptism, ${ }^{142}$ mixed with the blood ${ }^{143}$ of martyrdom. ${ }^{144}$ Holding the harps of God, the praises of God. ${ }^{145}$

5 The temple of the tabernacle of testimony in heaven was opened, the Scriptures [were opened] in the church.

6 Seven angels, seven orders of preachers. Clothed in a clean white stone. ${ }^{146} \mathrm{Christ}^{147}$ or the body of Christ is understood. Golden girdles, perfected minds. ${ }^{148}$

8 The temple was filled with smoke, the profoundness of the mysteries or compunction of heart. ${ }^{149}$

\section{Chapter 16}

1 Go and pour out the seven bowls of the wrath of God on the earth. It is spoken to preachers.

2 And the first went, the first proclamation, and poured out on the earth, upon sinners.

3 And onto the sea, upon the heathen world.

4 The third upon the rivers, upon heretics and persecutors.

8 And the fourth poured out his bowl onto the sun, that is, preaching and judgment onto the church.

9 They blasphemed the name of the Lord, they who fell away.

12 That a way might be prepared for the kings from the east, for those who enter into the church through faith.

15 Behold, he will come as a thief. [He who will come] is Christ. One who guards his garments, chastity.

19 And the great city was divided into three parts, that is, the whole world, one part [made up] of believers, another of unbelievers, and a third of the Antichrist. 
20 And every island fled, every church, ${ }^{150}$ and the mountains were not found, the saints ${ }^{151}$ or adversarial rulers.

21 And great hail, the heaviness of life.

\section{Chapter 17}

1 This harlot is understood as the whole world. Who is sitting upon waters, upon peoples. ${ }^{152}$

3 The beast is the Antichrist; the woman, the fornication of the whole world; scarlet on account of the blood of the martyrs. ${ }^{153}$

$4 A$ chalice in her hand, the will of the flesh.

\section{Chapter 18}

1 This angel is Christ. ${ }^{154}$

2 Babylon the Great has fallen, the human race.

19 And they threw dust upon their heads is understood as the remembrance of their sins.

20 Rejoice over her, heaven, that is, the powers of heaven. ${ }^{155}$

22 The sound of the mill, that is, the sound of preaching.

\section{Chapter 19}

11 Recapitulation. ${ }^{156}$ I saw heaven opened, the church. A white horse, Christ. ${ }^{157}$

12 On his head diadems, rewards.

15 Sharp sword, the word of God. ${ }^{158}$ That with it he may smite the nations, that is, [smite them] spiritually.

16 A robe, the saints. Through his thigh [is understood] those who are perfect in the married state.

17 This angel is Christ. Here birds are understood as either saints ${ }^{159}$ who convert sinners through preaching, as if they became their food, or according to another sense, adversarial powers who take vengeance upon sinners.

20 The false prophet is the Antichrist. Up to when [he says] the two were cast into the lake of fire, that is, the Antichrist with sinners.

\section{Chapter 20}

1 I saw an angel coming down from heaven holding the key of the abyss and a chain in [his] hand. This angel is the guard of hell. When Christ died, at that time he bound the devil. 
3 A thousand years is understood as the New Testament [age] ${ }^{160}$ because it is a perfect number, ${ }^{161}$ not as heretics think, that the devil is bound at the end of the world.

4 And they will reign with Christ for a thousand years, the righteous, that is, up to the Day of Judgment when they receive immortality. ${ }^{162}$

5 The first resurrection is of the righteous when they leave their body and go to rest. ${ }^{163}$

11 I saw a throne in heaven, the throne of God. From whose face heaven, adversarial powers, and earth, sinners, fled.

12 The dead, great on account of the multitude of their sins, [and] small, those who sinned less. Opened books, the conscience of each person. ${ }^{164}$

13 Death, which is hell. This lower earth is called hell, and the devil ${ }^{165}$ and Antichrist are called death.

\section{Chapter 21}

10 Here the city, Jerusalem, is understood as the church. ${ }^{166}$ Christ. ${ }^{167}$

11 Its brilliance [was] similar to a precious stone, that is, [similar] to

12 Great wall, faith. ${ }^{168}$

13 On the east three gates signifies those who come from infancy to the faith of the Trinity. ${ }^{169}$ On the north three gates, those who come from the domain of the devil. On the south three gates, those who are in the prosperity of the world and are converted through penitence. And on the west three gates, those who come in old age. ${ }^{170}$

15 With a reed, according to a historical interpretation, [something] is both measured and written. Golden reed is understood as gospel preaching.

16 The city was built in a square, that is, upon the four Gospels. Length of faith; width of charity; height of hope. ${ }^{171}$

18 Through gold, [is understood] the meaning of the Scriptures; through glass, baptism. ${ }^{172}$

21 Through the gates are understood the rulers of the churches. The street of the city is understood as the breadth of the commandments. ${ }^{173}$

19 These twelve stones are: the first [foundation] jasper, sapphire, chalcedony, emerald, 20 sardonyx, sardion, chrysolite, beryl, topaz, chrysophrase, hyacinth, [and] amethyst. These twelve stones contain a figure of the twelve apostles. They have diverse colors signifying the diversity of merits. 


\section{Chapter 22}

1 The river of the water of life, the divine Scriptures.

2 In the midst of the street, in the church. ${ }^{174}$ On each side of the river the tree of life, Christ in the Old and New Testament. ${ }^{175}$ Bearing fruits through each of the months, "through the teaching of the twelve apostles"176 up to the end of the world. Through the leaves are understood the farthest preachers. ${ }^{177}$

10 Do not seal up the words of this prophecy, that is, do not conceal them.

11 One who harms, let him harm still; and one who is in filth, let him be filthy still. He speaks of Jews, of heretics, or of the Antichrist, not in the imperative mood but declaring their unfaithfulness.

14 Blessed [are] they who wash their robes, that is, their bodies through chastity, through baptism, through martyrdom, or through penance. That their power may be in the tree of life, that they may have a part with Christ. And may enter through the gates into the city, that is, through the faith of the Trinity into the church.

15 Outside [are] dogs, Jews, and sorcerers, heretics, and the unclean, again heretics, and murderers, Jews, and worshippers of idols, heathen, and everyone who loves and practices falsehood, all sinners.

16 Christ sent his angel, that is, John. Bright star, Christ in the resurrection. ${ }^{178}$

17 And the Spirit and the bride say: Come! The church desires through the Holy Spirit that Christ comes for the judgment. And the one who hears, that is, whoever fulfils [the commands of] ${ }^{179}$ Holy Scripture, let him say: Come!

18 If anyone adds to these things, that is, heretics who have an incorrect understanding of the thousand years, [interpreting them] corporally, or have an incorrect understanding of the binding of the devil. ${ }^{180}$

19 If anyone takes away from the words of this prophecy, that is, in such a way that anything herein is not received. 


\section{NOTES}

${ }^{1}$ Jerome, On Hebrew Names, Acts; PL 23:848. Cf. Caesarius of Arles, Exposition of the Apocalypse of Saint John, homily 1; trans. Weinrich, 63.

${ }^{2}$ Cf. Gregory the Great, Moral Teaching on Job, preface, 3.

${ }^{3}$ Cf. Augustine, On the Literal Interpretation of Genesis, 12.6-7; Isidore of Seville, Etymologies, 7.8, 37-40.

${ }^{4}$ Isidore of Seville, Etymologies, 6.2, 49; PL 82:235.

${ }^{5}$ Cf. Isa 9:6.

${ }^{6}$ Pelagius, Commentary on the Epistle of Paul to Titus, On Titus 1:1; trans. Souter, 2, 525; Students of Cassiodorus [pseudo-Primasius], Commentary on the Epistle of Paul to Titus, on Titus 1:1; PL 68:679. Cf. John 8:34.

${ }^{7}$ Cf. Reference Bible, On the Mysteries of the Apocalypse of John, on Rev 1:2.

${ }^{8}$ Jerome, On Hebrew Names, 2 Tim, PL 23:856; Apringius of Beja, Explanation of the Revelation, on Rev 1:4, trans. Weinrich, 24; Bede, Exposition of the Apocalypse, on Rev 1:11, trans. Weinrich, 116.

${ }^{9}$ Cf. Isa 11:2-3; Victorinus of Pettau, Commentaries on the Apocalypse, on Rev 1:4, CSEL 49:16-17.

${ }^{10} \mathrm{Cf}$. Apringius of Beja, Explanation of the Revelation, on Rev 1:4, trans. Weinrich, 24; Bede, Exposition of the Apocalypse, on Rev 1:4, trans. Weinrich, 115.

${ }^{11} \mathrm{Cf}$. Victorinus of Pettau, Commentaries on the Apocalypse, on Rev 1:4, CSEL 49:16-17.

${ }^{12}$ Lat. testificavit.

${ }^{13}$ Cf. Heb 9:16-17.

${ }^{14}$ Victorinus of Pettau, Commentaries on the Apocalypse, on Rev 1:5, CSEL 49:18-19.

${ }^{15}$ Cf. Victorinus of Pettau, Commentaries on the Apocalypse, on Rev 1:6, CSEL 49:18-19.

${ }^{16}$ Cf. Heb 7:3.

${ }^{17}$ Cf. Acts 1:9.

${ }^{18}$ Cf. Matt 24:29-30.

${ }^{19}$ Jerome, On Hebrew Names, Apoc, PL 23:902.

${ }^{20}$ Jerome, On Hebrew Names, Apoc, PL 23:902. Lat. deorsum fluens, or perhaps "flowing backward."

${ }^{21}$ Cf. Jerome, Against Helvidius, 16. NPNF, 2nd ser. 6:341; Isidore of Seville, Etymologies, 9.6, 8 .

${ }^{22}$ Lat. novo testamento or perhaps "New Testament."

${ }^{23}$ Lat. tenuit or "contained."

${ }^{24}$ Cf. Isa 58:1.

${ }^{25} \mathrm{Cf}$. Reference Bible, On the Mysteries of the Apocalypse of the Apostle John, prologue.

${ }^{26}$ Jerome, On Hebrew Names, Apoc, PL 23:902-03.

${ }^{27}$ Cf. Isa 11:2-3.

${ }^{28}$ Cf. Victorinus of Pettau, Commentaries on the Apocalypse, on Rev 1:13b, CSEL 49:2223; Reference Bible, On the Mysteries of the Apocalypse of the Apostle John, on Rev 1:13.

${ }^{29}$ Cf. 1 Cor 11:3; Victorinus of Pettau, Commentaries on the Apocalypse, on Rev 1:14, CSEL 49:20-21.

${ }^{30}$ Cf. Victorinus of Pettau, Commentaries on the Apocalypse, on Rev 1:15a, CSEL 49:26-27.

${ }^{31}$ Cf. Eph 6:17.

${ }^{32}$ I have followed not Gryson's edition, which has the masculine qui, but manuscripts 
B (ninth century), G (twelfth century), H (twelfth century), and Rapisarda's edition, which have the neuter quod ("which") matching the neuter gender of verbum ("word"). The comment seems to be an allusion to the description of the word of God in Heb 4:12.

${ }^{33}$ Cf. Heb 4:12.

${ }^{34}$ Cf. Matt 13:43; Tyconius, Exposition of the Apocalypse, on Rev 1:16, CCSL 107A:109.

${ }^{35}$ Gryson's edition has languentes in the nominative or accusative plural. I have followed manuscripts $\mathrm{A}$ and $\mathrm{K}$, which have languentis in the genitive singular.

${ }^{36}$ Jerome, On Hebrew Names, Apoc, PL 23:858. Pseudo-Jerome has stultum or "fool," while Jerome has stultitia or "foolishness."

${ }^{37}$ Cf. Bede, Exposition of the Apocalypse, on Rev 2:7, trans. Weinrich, 118.

${ }^{38}$ Cf. Reference Bible, On the Mysteries of the Apocalypse of John, on Rev 2:10.

${ }^{39}$ Jerome, On Hebrew Names, Apoc, PL 23:857.

${ }^{40}$ Jerome, On Hebrew Names, Apoc, PL 23:857. Jerome has "Where is the dunghill?"

${ }^{41}$ Cf. Victorinus of Pettau, Commentaries on the Apocalypse, 2.4, CSEL 49:38-39.

${ }^{42}$ Cf. John 14:6.

${ }^{43}$ Cf. Bede, Exposition of the Apocalypse, on Rev 3:12, trans. Weinrich, 123.

${ }^{44}$ Cf. 1 Pet 4:8.

${ }^{45}$ Lat. miserabilis apud deum, meaning "in need of God's mercy (misericordia)."

${ }^{46} \mathrm{Cf}$. Augustine, Tractates on the Gospel of John, 2.16, NPNF, 1st ser., 7:18.

${ }^{47}$ Lat. non de loco ad locum, literally "from place to place."

${ }^{48}$ Cf. Reference Bible, On the Mysteries of the Apocalypse of John, on Rev 4:3.

${ }^{49}$ For the interpretation of lightning as miracles and of the voices as preaching, cf. Caesarius of Arles, Exposition of the Apocalypse of Saint John, homily 3, trans. Weinrich, 69. Bede in his Exposition of the Apocalypse simply cites Mark 16:20, which mentions the preaching and miracles of the apostles; trans. Weinrich, 125.

${ }^{50}$ For the interpretation of thunder as threats, cf. Victorinus of Pettau, Commentaries on the Apocalypse, on Rev 4:4, CSEL 49:56-57.

${ }^{51}$ Cf. Apringius of Beja, Explanation of the Apocalypse, on Rev 4:6, CCSL 107:62; Reference Bible, On the Mysteries of the Apocalypse of John, on Rev 4:6.

${ }^{52}$ Tyconius, Exposition of the Apocalypse, on Rev 4:6, CCSL 107A:131.

${ }^{53}$ Victorinus of Pettau, Commentaries on the Apocalypse, on Rev 4:3, trans. Weinrich, 7.

${ }^{54}$ Cf. Victorinus of Pettau, Commentaries on the Apocalypse, on Rev 4:5, trans. Weinrich, 8.

${ }^{55}$ Cf. Primasius of Hadrumetum, Commentary on the Apocalypse, on Rev 4:8, where he writes that six is used "because the Apostle recalls the things that transpired in the sixth age, that is, in [Christ's] coming in the fullness of times."

${ }^{56}$ Tyconius, Exposition of the Apocalypse, on Rev 4:8, CCSL 107A:133.

${ }^{57}$ Cf. Apringius of Beja, Explanation of the Apocalypse, on Rev 4:11, trans. Weinrich, 43.

${ }^{58} \mathrm{Cf}$. Reference Bible, On the Mysteries of the Apocalypse of John, on Rev 4:10.

${ }^{59}$ Cf. Isa 11:2.

${ }^{60}$ An angel in the generic sense, not a specific type from the nine orders of angels. See his comments on Rev 5:13.

${ }^{61}$ Cf. Tyconius, Exposition of the Apocalypse, on Rev 5:11, CCSL 107A:136.

${ }^{62}$ Cf. Gregory the Great, Homilies on the Gospels, 34.6, PL 76:1249.

${ }^{63}$ Lat. praedicationes or "preachings." 
${ }^{64} \mathrm{Cf}$. Caesarius of Arles, Exposition of the Apocalypse of Saint John, homily 5, where he says the white horse represents the church; trans. Weinrich, 72.

${ }^{65}$ Cf. Heb 4:12.

${ }^{66}$ Cf. Caesarius of Arles, Exposition of the Apocalypse of Saint John, homily 5, trans. Weinrich, 72; Reference Bible, On the Mysteries of the Apocalypse of John, on Rev 6:5.

${ }^{67}$ Cf. Job 1:12.

${ }^{68}$ Cf. Isidore of Seville, Etymologies, 16.26.

${ }^{69}$ Cf. Reference Bible, On the Mysteries of the Apocalypse of John, on Rev 6:6.

${ }^{70}$ Other Old Latin versions of Scripture of the African grouping, such as those used by Tyconius and Primasius, have a "fourth part".

${ }^{71}$ Cf. Amos 8:12.

${ }^{72}$ Here the commentator gives two solutions to the theological problem of reconciling the martyrs' imprecations against their enemies with the gospel ordinance to love and pray for one's enemies. Cf. Primasius of Hadrumetum, Commentary on the Apocalypse, on Rev 6:10, CCSL 92:99-100; Bede, Exposition of the Apocalypse, on Rev 6:10, trans. Weinrich, 130 .

${ }^{73}$ Cf. Primasius of Hadrumetum, Commentary on the Apocalypse, on Rev 6:11, CCSL 92:96.

${ }^{74}$ In the late fourth century, Helvedius, Jovinian, and Vigilantius, in their efforts to equalize the status of all believers in reaction to exaltation of the state of celibacy, were accused of denying that there is a diversity of glory in heaven based on merits earned on earth. Therefore, lest one think that because each in Rev 6:11 are given a robe, each had received the same reward, the author asserts the "orthodox" position.

${ }^{75}$ Lat. terraemotus, literally, "a movement of the earth"; hence, the comments about movement in and out of the faith.

${ }^{76}$ Lat. qui liber est a servitute dei. Cf. Rom 6:20.

${ }_{77}^{7}$ Lat. ministris. Angels are called ministros in Heb 1:7.

${ }^{78} \mathrm{Cf}$. Bede, Exposition of the Apocalypse, on Rev 7:2, trans. Weinrich, 132.

${ }^{79}$ Cf. Bede, Exposition of the Apocalypse, on Rev 7:2, trans. Weinrich, 132; Reference Bible, On the Mysteries of the Apocalypse of John. On Rev 7:2.

${ }^{80}$ Most biblical versions have "I heard" here.

${ }^{81}$ Cf. Cyprian of Carthage, Ad Fortunatum, ANF 5:505; Ad Quirinum, 16, ANF 5:538.

${ }^{82}$ Cf. Bede, Exposition of the Apocalypse, on Rev 7:5, trans. Weinrich, 133.

${ }^{83}$ Cf. Bede, Exposition of the Apocalypse, on Rev 7:5, trans. Weinrich, 133. This belief was based upon Gen 49:17 and Jer 8:16, and was the view of Irenaeus of Lyons (Against Heresies, 5.30.2, ANF 1:559) and Hippolytus of Rome (On Christ and the Antichrist, 15, ANF 5:207).

${ }^{84}$ Cf. Tyconius, Exposition of the Apocalypse, on Rev 7:9-10, CCSL 107A:149.

${ }^{85}$ Lat. omnis creatura or "all creation."

${ }^{86}$ That is, all the things in Rev 7:12: blessing, glory, wisdom, thanksgiving, honor, power, and might.

${ }^{87}$ Cf. Tyconius, Exposition of the Apocalypse, on Rev 8:1, CCSL 107A:152.

${ }^{88}$ Cf. Isa 11:2.

${ }^{89}$ The comments on Rev 8:3 are dependent upon Tyconius, Exposition of the Apocalypse, on Rev 8:3, CCSL 107A:152-53. 
${ }^{90}$ Cf. Reference Bible, On the Mysteries of the Apocalypse of John, on Rev 8:5, which says "from divinity."

${ }^{91}$ Lat. inperfectiores.

${ }^{92}$ Cf. Tyconius, Exposition of the Apocalypse, on Rev 8:8, CCSL 107A:154.

${ }^{93}$ The idea is that as the heavenly bodies display varying brightness, so believers vary. Cf. Matt 13:23; 1 Cor 15:41; Reference Bible, On the Mysteries of the Apocalypse of John, on Rev 8:12.

${ }^{94}$ Cf. 1 Thess 5:5.

${ }^{95}$ Cf. Reference Bible, On the Mysteries of the Apocalypse of John, on Rev 9:3.

${ }^{96}$ Cf. Primasius of Hadrumetum, Commentary on the Apocalypse, on Rev 9:5, CCSL 92:149.

${ }^{97}$ Lat. voluntas or perhaps "desire." Cf. 2 Tim 3:6; Primasius of Hadrumetum, Commentary on the Apocalypse, on Rev 9:7, CCSL 92:150; Reference Bible, On the Mysteries of the Apocalypse of John, on Rev 9:8-9.

${ }^{98}$ Cf. Reference Bible, On the Mysteries of the Apocalypse of John, on Rev 9:8-9.

${ }^{99}$ Cf. Reference Bible, On the Mysteries of the Apocalypse of John, on Rev 9:17.

${ }^{100}$ Lat. luxuriam.

${ }^{101}$ Cf. Caesarius of Arles, Exposition of the Apocalypse of John, homily 7, trans. Weinrich 79; Primasius of Hadrumetum, Commentary on the Apocalypse, on Rev 9:15, CCSL 92:153; Reference Bible, On the Mysteries of the Apocalypse of John, on Rev 9:15.

${ }_{102}$ Cf. Tyconius, Exposition of the Apocalypse, on Rev 9:17, CCSL 107A:161.

${ }^{103}$ Cf. Primasius of Hadremetum, Commentary on the Apocalypse (on Rev 10:1, CCSL 92:159), who says "Christ the Lord." Similarly, Victorinus, Tyconius, Caesarius, and Bede all say that the angel represents "the Lord."

${ }^{104}$ Cf. Primasius of Hadrumetum, Commentary on the Apocalypse, on Rev 10:1, CCSL 92:159.

${ }^{105}$ Cf. Rom 10:15; Caesarius of Arles, Exposition of the Apocalypse of John, homily 7, trans. Weinrich, 81; Primasius of Hadrumetum, Commentary on the Apocalypse, on Rev 10:1, CCSL 92:160.

${ }^{106}$ Cf. Tyconius, Exposition of the Apocalypse, on Rev 10:2, CCSL 107A:164; Reference Bible, On the Mysteries of the Apocalypse of John, on Rev 10:2.

${ }^{107}$ Cf. Tyconius, Exposition of the Apocalypse, on Rev 10:2, CCSL 107A:164; Reference Bible, On the Mysteries of the Apocalypse of John, on Rev 10:2.

${ }^{108}$ Cf. Isa 11:2; Victorinus of Pettau, Commentaries on the Apocalypse, on Rev 10:3, CSEL 49:90-91; Bede, Exposition of the Apocalypse, on Rev 10:3, trans. Weinrich, 144; Reference Bible, On the Mysteries of the Apocalypse of John, on Rev 10:3.

${ }^{109}$ Cf. Reference Bible, On the Mysteries of the Apocalypse of John, on Rev 10:2, 9.

${ }^{110}$ Cf. Reference Bible, On the Mysteries of the Apocalypse of John, on Rev 10:9.

${ }^{111}$ Lat. voluntas or "desire."

${ }^{112}$ Cf. Luke 18:29-30.

113 Gryson's critical edition indicated that iterum or "again" is the reading of manuscript $L$, but manuscripts $B, K$, and $M$ have illum.

${ }^{114}$ Cf. 2 Cor 10:13.

${ }^{115}$ Cf. Tyconius, Exposition of the Apocalypse, on Rev 11:2, CCSL 107A:166.

${ }_{116}$ Cf. Reference Bible, On the Mysteries of the Apocalypse of John, on Rev 11:2.

${ }^{117}$ Cf. Reference Bible, On the Mysteries of the Apocalypse of John, on Rev 11:8. 
${ }^{118}$ Cf. Heb 12:22-23.

${ }^{119}$ Victorinus of Pettau, Commentaries on the Apocalypse, on Rev 12:1, CSEL 49:106.

${ }^{120}$ Similar to the phases of the moon.

${ }^{121}$ Cf. Tyconius, Exposition of the Apocalypse, on Rev 12:1, CCSL 107A:175.

${ }^{122}$ Cf. Reference Bible, On the Mysteries of the Apocalypse of John, on Rev 12:2.

${ }^{123}$ Cf. Rev 12:9.

${ }^{124}$ Cf. Reference Bible, On the Mysteries of the Apocalypse of John, on Rev 12:3.

${ }^{125}$ Cf. Isa 11:2.

${ }^{126}$ Cf. Rev 17:12. Victorinus of Pettau, Commentaries on the Apocalypse, on Rev 12:3, says that these will be ten kings at the end of time; trans. Weinrich, 16.

127 The Mosaic law and the law of Christ.

${ }^{128}$ Cf. Primasius of Hadrumetum, Commentary on the Apocalypse, on Rev 12:14, CCSL 92:187. The commandment to love God with all one's heart and to love one's neighbor is based on Luke 10:27.

${ }^{129}$ The wording of the comment on this phrase varies much in the manuscripts. If this is the correct reading, the author may have had access to traditions, based on Dan 2 and 7 and 2 Thess 2:6-7, such as those in the Apocalypse of pseudo-Methodius, which held that the kingdom of the Romans would be successful over the armies of Antichrist, except at the very end. Or, the author may have in mind the final overthrow of Arian monarchs in Western Europe (ca. 671) by Roman Catholic monarchs, which acts as a prefigure of the overthrow of the future Antichrist when he revives Arianism (cf. comments on Rev 13:14-17) On proud kings prefiguring Antichrist, see his comment on Rev 13:1.

${ }^{130}$ Cf. 3 John 1:9.

${ }^{131}$ Based on the comment on verse 17, the heresy he is referring to in comments on verses $14-15$ is probably a form of Arianism, which denied the full divinity of Christ and the Trinity. Many Visigothic, Ostrogothic, and Lombard kings were semi-Arian (technically homoian) in Christology well into the fifth, sixth, and seventh centuries before converting to Catholicism.

${ }^{132}$ Lat. per septem dies.

${ }^{133}$ Cf. Tyconius, Exposition of the Apocalypse, on Rev 14:5, CCSL 107A:188.

${ }^{134}$ Cf. Tyconius, Exposition of the Apocalypse, on Rev 14:6, CCSL 107A:189; Reference Bible, On the Mysteries of the Apocalypse of John, on Rev 14:6.

${ }^{135}$ Cf. Tyconius, Exposition of the Apocalypse, on Rev 14:8, CCSL 107A:189.

${ }^{136}$ Cf. Tyconius, Exposition of the Apocalypse, on Rev 14:8, CCSL 107A:189.

${ }^{137}$ Cf. Tyconius, Exposition of the Apocalypse, on Rev 14:9, CCSL 107A:190.

${ }^{138}$ Cf. Tyconius, Exposition of the Apocalypse, on Rev 14:14, CCSL 107A:191.

${ }^{139}$ Cf Tobit 8:3.

${ }^{140}$ Lat. perfectus, or perhaps it signifies the completeness of the judgment.

${ }^{141}$ Tyconius, Exposition of the Apocalypse, on Rev 14:20, CCSL 107A:193.

${ }^{142}$ Cf. Tyconius, Exposition of the Apocalypse, on Rev 15:2, CCSL 107A:194.

${ }^{143}$ Lat. mixtum sanguine. This reading was contained in some versions of the Apocalypse for mixtum igne, "mixed with fire."

${ }^{144}$ Cf. Primasius of Hadrumetum, Commentary on the Apocalypse, on Rev 15:2, CCSL 92:221: "the redness of martyrdom."

${ }^{145}$ Cf. Tyconius, Exposition of the Apocalypse, on Rev 15:2, CCSL 107A:194.

${ }^{146}$ Lat. lapide (stone) corresponding to the ancient Greek reading lithon. But most 
Greek manuscripts had linon (linen) which was rendered variously in the Latin versions as linum (Tyconius), linea (Primasius), and lenteamine (Reference Bible, Codex Gigas). Bede (CCSL 121A:443-45) was familiar with a Latin version that read lapide and another version that read linteamen.

${ }^{147}$ Cf. 1 Pet 2:6, where Christ is called the chief cornerstone.

${ }^{148}$ Lat. perfectos sensus. For Primasius of Hadrumetum (CCSL 92:223) and Bede (trans. Weinrich, 163) the gold signifies wisdom. And Primasius continues: "In the law a priest is often ordered to wear around his chest a logium, that is, rationality, so that his mind is well aware of divine things."

${ }^{149}$ Cf. Reference Bible, On the Mysteries of the Apocalypse of John, on Rev 15:8.

${ }^{150}$ Cf. Reference Bible, On the Mysteries of the Apocalypse of John, on Rev 16:20.

${ }^{151}$ Cf. Reference Bible, On the Mysteries of the Apocalypse of John, on Rev 16:20.

${ }^{152}$ Cf. Rev 17:15; Tyconius, Exposition of the Apocalypse, on Rev 17:1, CCSL 107A:203.

${ }^{153}$ Cf. Tyconius, Exposition of the Apocalypse, on Rev 17:3, CCSL 107A:204.

${ }^{154}$ Cf. Primasius of Hadrumetum, Commentary on the Apocalypse, on Rev 18:2, CCSL 92:251; Bede, Exposition of the Apocalypse, on Rev 18:1, trans. Weinrich, 171; Reference Bible, On the Mysteries of the Apocalypse of John, on Rev 18:1.

${ }^{155} \mathrm{He}$ refers to the angels.

${ }^{156}$ Cf. Tyconius, Exposition of the Apocalypse, on Rev 19:11, CCSL 107A:215.

157 Cf. Victorinus of Pettau, Commentaries on the Apocalypse, on Rev 19:11, CSEL 49:136-37.

${ }^{158}$ Cf. Eph 6:17; Heb 4:12; Reference Bible, On the Mysteries of the Apocalypse of John, on Rev 19:15.

${ }^{159}$ Cf. Bede, Exposition of the Apocalypse, on Rev 19:17, trans. Weinrich, 177.

${ }^{160}$ Cf. Reference Bible, On the Mysteries of the Apocalypse of John, on Rev 20:2.

${ }^{161}$ Cf. Primasius of Hadrumetum, Commentary on the Apocalypse, on Rev 20:1-2, CCSL 92:272, citing Augustine, On the City of God, 20.7, trans. Dods, 720.

${ }^{162}$ Cf. 1 Cor 15:53.

163 Cf. Primasius of Hadrumetum, Commentary on the Apocalypse, on Rev 20:4, CCSL 92:276, citing Augustine, On the City of God, 20.9, trans. Dods, 726-27.

${ }^{164}$ Cf. Bede, Exposition of the Apocalypse, on Rev 20:12, 20:15, trans. Weinrich, 180-81.

${ }^{165}$ Cf. Tyconius, Exposition of the Apocalypse, on Rev 20:14, CCSL 107A:222.

${ }^{166}$ Cf. Tyconius, Exposition of the Apocalypse, on Rev 20:10, CCSL 107A:223.

${ }^{167}$ Cf. Tyconius, Exposition of the Apocalypse, on Rev 21:11, CCSL 107A:223; 1 Pet 2:6.

${ }^{168}$ Cf. Reference Bible, On the Mysteries of the Apocalypse of John, on Rev 21:12.

${ }^{169}$ Cf. Reference Bible, On the Mysteries of the Apocalypse of John, on Rev 21:13. The Latin term for "east" (oriens) means "rising." Hence, the connection between the beginning of the sun's path and the beginning of a person's life.

${ }^{170}$ Cf. Reference Bible, On the Mysteries of the Apocalypse of John, on Rev 21:13. The Latin term for "west" (occidens) means "dying." Hence, the comment on old age.

${ }^{171}$ Gryson's edition says that these comments on the length, width, and height are very often read in the Fathers, and among others cites Gregory the Great, Homilies on Ezekiel, 2.7, 2.

${ }^{172}$ Cf. Reference Bible, On the Mysteries of the Apocalypse of John, on Rev 21:18.

${ }^{173}$ From the comment, it is likely that the commentator understood platea, which I have translated "street," more like a "plaza." 
174 Cf. Tyconius, Exposition of the Apocalypse, on Rev 22:1-2, CCSL 107A:226.

175 Cf. Apringius of Beja, Explanation of the Apocalypse, on Rev 22:2, trans. Weinrich, 60.

176 Tyconius, Exposition of the Apocalypse, on Rev 22:2, CCSL 107A:226.

177 Lat. extremi praedicatores, as leaves are farthest from the trunk of the tree. But he may mean "the last preachers" before the end of the world.

178 Cf. Primasius of Hadrumetum, Commentary on the Apocalypse, on Rev 22:16, CCSL 92:309.

179 The author also uses the verb implere in this way in his comments on Rev 10:8, 11.

180 The comment is directed against chiliasts of the Cerinthian type, whose future millennium was accused of being replete with corporeal delights such as feasting and procreation. Cf. Jerome, Commentary on the Apocalypse, on Rev 21:25, CSEL 49:153: "Therefore, they should not be listened to, who affirm that the kingdom of the thousand years is earthly, who believe like the heretic Cerinthus. For, the kingdom of Christ, which now is, will be eternal, when the glory of the saints after the resurrection will have been manifested." See also Filastrius of Brixia, Book of Various Heresies, 59, CCSL 60:242; and Isidore of Seville, On Heresies, PLS 4:1816. Chiliasts usually saw the binding of the devil as not occurring at the Incarnation but awaiting a future millennium, an opinion which pseudoJerome rejects. 


\section{Reference Bible \\ On the Mysteries of the Apocalypse of John}

\section{Preface}

John wrote this book when the emperor Domitian banished him to the island of Patmos, ${ }^{1}$ so that to the extent that he was farther away from people, he was that much closer to God. And although he was prohibited from preaching and speaking to people, he spread abroad the word of God all the more, saying: In the beginning was the Word, etc. (John 1:1). ${ }^{2}$

Concerning the Apocalypse, Origen and Jerome say that he wrote the Gospel first, and afterwards the Apocalypse, ${ }^{3}$ but Gregory and Isidore say that he wrote the Apocalypse first, and afterward the Gospel. ${ }^{4}$ How is there agreement? That is, the Apocalypse was revealed to him on the island of Patmos first, that is, he wrote it in his heart; and afterwards, having been asked by the brothers of Asia, he wrote the Gospel; and after that he wrote the Apocalypse.

"In the Apocalypse," Jerome says, "there are as many mysteries as there are words, and I have said little. For, hidden in these words are two levels of understanding." 5

\section{Chapter 1}

1 The Apocalypse of Jesus Christ, which God gave to him to make plain to his servants the things which must happen shortly. Apocalypse is Greek and "is interpreted as Revelation" because it was to be revealed in the form in which it was shown. ${ }^{7}$ OfJesus Christ because the things which are written in it are about Christ and the church. Or, of Jesus Christ because Jesus Christ revealed it to John. Gave to him, that is, the Father to Christ, or Christ to John, to make plain, that is, to show simply without a parable, what things must happen shortly, that is, the necessary things which are quickly running to the end of time; for whatever regards the end, is completed quickly.

Primasius likewise says: "John was sent into exile on the island of Patmos by Domitian for [preaching] Christ. He was both 'condemned to 
the mine ${ }^{8}$ and imprisoned in the mines, so that where he is chained by a human guard, there, mentally transcending the limits of humanity, he had merited to see divine things with free observance. And to him who at that time was denied [permission] to leave earthly regions, it was granted to penetrate heavenly secrets. Thus everywhere the faith of Christ is opened to eternal things, when the church is suffering in temporal things. For the general matters of the whole church are revealed to one who was suffering, with the result that future things are predicted for all."

And he signified sending his angel, 2 who bore witness to the word of God and testimony of Jesus Christ. He signified, that is, he showed it obscurely, ${ }^{10}$ sending [his] angel, that is, Christ sent John, who bore witness, that is, saying, In the beginning was the Word, etc. (John 1:1). ${ }^{11}$ And testimony of Jesus Christ, that is, The Word was made flesh, etc. (John 1:14).

3 Blessed is the one who reads and those who hear and keep the words of the prophecy of this book, that is, blessed is the teacher who teaches and the student who hears ${ }^{12}$ and those who keep them by good works. ${ }^{13}$

The time is near. 4 John to the seven churches which are in Asia. That is, the time of retribution is near. And John, "one looking after the unity"14 of the church, which is one because there is one spouse and one dove (Songs 6:8). And seven [churches] because of the seven gifts of the Holy Spirit, ${ }^{15}$ and because of the seven steps (Ezek 40:22, 40:26) of the church. ${ }^{16}$ In Asia, that is, in the world, because Asia is interpreted as "world." 17

Grace to you and peace from him who is and who was and who is to come, and from the seven spirits which are before the throne. That is, the grace of remission of sins through Christ, and the peace of reconciliation for pardon from the Father through repentance. And from the seven spirits, that is, from the sevenfold Spirit. ${ }^{18}$ Which are before the throne, that is, the throne of God is the church. ${ }^{19}$

5 And from Jesus Christ, who is the faithful witness, the firstborn of the dead. That is, Christ, the faithful witness who said to Pontius Pilate ${ }^{20}$ : For this was I born, that I might bear witness to the truth (John 18:37). And firstborn of the dead, that is, who rose first. ${ }^{21}$ Or he is called firstborn for this reason, because he was begotten in divinity before the mortal elements had been made.

6 To him be glory and power unto the ages of ages. ${ }^{22}$ Amen. That is, glory in heaven and power on earth. Unto the ages, of eternity, of ages, of short times. Amen in Hebrew, and in Greek ginoito, ${ }^{23}$ and in Latin "truly" or "faithfully." 24 This is the little phrase by which the Lord confirms his words, as [in the Gospel] according to Matthew: Amen, truly I say to you, heaven 
and earth will pass away, but my words will not pass away (Matt 24:34-35). Amen, amen according to John (1:51) is as if he had said, "The truth, the truth I speak." Since every man is a liar, but God is true (Rom 3:4), man is a liar from himself; God is true from himself. ${ }^{25}$ But Paul says: I speak the truth in Christ; I lie not (Rom 9:1). He does not lie, but not from his [own ability], as Job did not sin with his lips (Job 2:10); for [such ability] is from God.

7 Behold, he comes with the clouds of heaven, and every eye will see him, even those who pierced him. All the tribes of the earth will mourn over him. With the clouds, that is, he ascended in a cloud, as it is said: And a cloud took him from their eyes (Acts 1:9). In the same manner he will come in a cloud, as it is said: In the same way in which you have seen, etc. (Acts 1:11). Or with clouds, with the heavenly powers, ${ }^{26}$ which are called clouds in comparison to the glory of divinity. And every eye will see him. How is this true, when it is said: The ungodly is removed, that he should not see the glory of God (Isa 26:10)? [The solution] is: By every eye he will be seen in his flesh with which he saved the world; nevertheless, he will appear in the glory of his divinity only to the elect. Even those who pierced him, that is, they will look upon him whom they have pierced (John 19:37). They will mourn over him, ${ }^{27}$ that is, over him whom they have pierced, while vengeance is being taken upon them. Or they will mourn over themselves, since they have not imitated the passion of the Lord. All the tribes of the earth, that is, those who fight for and serve earthly things.

8 I am the Alpha and Omega, the beginning and the end, says the Lord, who is and who was and who is to come. Why does he say these letters here? To indicate that the Lord is the first and the last (Rev 1:11, 1:17). For three tenses are here: the present, when he says $I$ am; the past, when he says Alpha, because this letter is placed first in the order of the Greek alphabet; and the future, when he says Omega, because that letter is last in the rudimentary order among the Greeks. Why did he not say "aleph" and "tau," the first and last [letters] in the alphabet of the Hebrews? For this reason: because this book was written in the Greek language and was written for Greeks. Why does he say: The first and the last (Rev 1:11, 1:17)? That is, the beginning because he was before the ages; the end because he took on flesh, in which flesh he accepted a deadly end. Or, first because he created the world, and last because he will consummate it. ${ }^{28}$ Or he said those two letters for this reason: because when an alpha is written by the Greeks, it signifies the eternity of the divinity; but the omega, short [of a circle], signifies the brevity of humanity. Or the Lord chose for himself these two 
letters for this reason: because each is a part of the shape of the other, ${ }^{29}$ as Isidore says: "And Christ chooses ${ }^{30}$ for himself two remaining letters, the first and the last. For he is the beginning, and he is the end, saying: I am the Alpha and Omega. Moreover, [when written] each runs into the another; the alpha replicates the omega until it curves; and again the omega replicates the alpha, so that the Lord might show in them both the course of the beginning to the end and the course of the end to the beginning." 31

10 I was in the spirit on the Lord's day, that is, my spirit was snatched from me, so that I might see in the power of the spirit what I was not able to see in the power of the flesh. I was in the spirit. Why did he not say: "The Spirit was in me?" That is, for the sake of humility, because he knew that he was small in comparison to the divine Spirit. And likewise on the Lord's day, that is, so that [he might indicate that] what he saw concerning Christ, he had seen in the resurrection of Christ.

I heard behind me a loud voice. That is, it is the custom of human nature to turn oneself away from God, unless God calls him back, as he says through the prophet: Turn to me, and I shall be turned (Mal 3:7; cf. Jer 31:18). In another manner of interpreting it: the church has become divided around Christ. One part turns its back against Christ, the part which follows only the letter or which falls into heresy. With that part John joins himself for the sake of humility. And there is another part, which follows the examples of Christ. Or John here is a figure of Adam, who heard the voice of the Lord behind him saying: Where are you, Adam, etc. (Gen 3:9).

12 I turned to see the voice which was speaking with me. And I saw seven candlesticks. 13 And in the midst of them the likeness of a man, clothed with a garment and girt about the breasts with a golden girdle. 14 And [his] head and hair were like white wool and his eyes as a flame of fire. 15 And [his] feet like fine brass in a blazing furnace, and his voice as the sound of many waters. 16 And he had in his right hand seven stars, and from his mouth [came] a sharp two-edged sword. And his face [was] as the sun in its power. 17 And I fell at his feet as dead. And he placed his right hand upon me saying, Do not be afraid. I am the first and the last. 18 And I am alive, and I was dead. And behold I live forever, and I have the keys of death and hell.

12 I turned, that is, the imperfect part of the church needing to be converted in order to hear the voice of Catholic doctrine. To see the voice with the mind, because the eye of his inner man saw the Word of God, just as the eye of his outer $\operatorname{man}^{32}$ saw his flesh. Seven candlesticks, the seven steps (Ezek 40:22, 26) in the church. 16 Seven stars, the teachers of the church with the seven gifts of the Holy Spirit. ${ }^{33}$ 
13 Golden, tried in faith and through temptations, and shining with the light of righteousness and doctrine. The likeness of the Son ${ }^{34}$ of Man, that is, of Christ. Nevertheless, he did not say [merely] "man," but the likeness of the Son of Man, because he was not born through intercourse with a man. Clothed with a garment. ${ }^{35}$ Moreover, a poderis is a priestly garment, ${ }^{36}$ that is, a wedding tunic. It was fitting that Christ, who offered himself for the world on the cross, who first offered his body and blood, and who offers holy souls to the Father, was seen in priestly clothing. ${ }^{37}$ About the breasts, that is, to the height of divinity.

14 Head, God the Father, as Paul says: The head of Christ is God (1 Cor 11:3). ${ }^{38}$ Hair, the angels. Eyes flames ${ }^{39}$ of fire, "that is, the divine inspections," ${ }^{40}$ through which the Lord sees us, as if we are examined ${ }^{41}$ through a flame of fire.

15 Feet, the apostles. ${ }^{42}$ Fine brass, which is turned into gold through fire. In this way the apostles are led through fire, temptations, and persecutions, into their future forms after the resurrection. His voice as of waters, that is, the voice of the entire Old and New [Testament] Scripture, as it is written: Deep [calls out to] deep, etc. (Ps 42:7).

16 In his right hand, that is, in his power. A sharp two-edged sword, that is, the word of God ${ }^{43}$ judges over the body and the soul. ${ }^{44}$ Face [was] as the sun, that is, Catholic rulers and teachers, who teach the contemplative life. ${ }^{45}$

17 I fell at [his] feet, that is, at the apostles, as one who had done penance. Dead, that is, in the letter, because the letter kills (2 Cor 3:6). Alive, that is, in the Spirit of God. He placed [his] right hand, that is, his assistance. ${ }^{46}$ Do not be afraid, that is, do not be afraid to repent, since the kingdom of heaven is at hand (Matt 3:2).

18 Alive in the resurrection, dead on the cross. I have the keys, that is, of life, as I lead people in the present life. Or [the keys] of eternity, or into the future life. And of death, ${ }^{47}$ that is, in the present, as [it is written]: Do not fear those who kill the body, etc. (Matt 10:28)

\section{Chapter 2}

5 Remember from where you have escaped, and repent, and perform your former works. That is, remember from where you have fallen, that is, what kind of rank, or height, or religion you have forsaken, and repent, that is, repent in a way that corresponds with the rank or the height or the religion you have had, and perform your former works, that is, against the heretics who say that no one is able to restore their former works. ${ }^{48}$

And I will move [your] candlestick, that is, I will remove from you 
the good which you have, that it may be given to the good part. Or [I will remove your] wisdom, or your share of eternal life for which you hope. From [its] place, that is, from you. Nevertheless, he does not say, "I will take away," but "I will move," as if had said: "Whatever this part loses, will be given to another," ${ }^{\prime 49}$ that is, whatever purity is lost will be given to the other part after repentance. Or I will move [your] candlestick, that is, the reward of the work of someone in the church, and when it is lost, it will be given to the other part which does good work. And we understand similarly concerning sinners, that the judgment of the evil work of those who repent is given over to the sinners remaining in sin.

7 To the one who overcomes I shall give him to eat from the tree of life, which is in the paradise of my God. That is, I shall give to the one who overcomes, the one who denies himself (Matt 16:24; Luke 9:23), or the one who overcomes the deeds of the Nicolaitans, who are called [such] after Nicholas. ${ }^{50}$ Moreover, everyone who speaks heresy is a Nicolaitan. The works of the Nicolaitans are these: idolatry and fornication. Moreover, Nicolaitans are interpreted "those having flowed" 51 in fornication. To eat from the tree of life, that is, he will partake of everlasting life which is in the kingdom of God. Moreover, the tree of life was in the paradise of Adam, from which if anyone had eaten, he would not have seen death. Or, from the tree of life, "from the fruit of the cross." ${ }^{2}$ Moreover, "paradise is the church," 53 in which the body and blood of Christ is consumed.

10 Behold, the devil will send [some] of you into prison, that you should be tested; and you will have tribulation ten days. That is, the devil, who is in prison, will send [some] of you sinners [into prison] at the end of the world, that you should be tested. Surely he is speaking not only to the church at Smyrna but to all Christians. Ten days, that is, he has put the finite for the infinite. In this number she rests. ${ }^{54}$ Or because there are no numbers that are able to exceed ten. ${ }^{55}$ Or because of the ten commandments of the law that should be obeyed. Or because of the five senses of the soul and [five of the] body. ${ }^{56}$

11 The one who has ears for hearing, let him hear, that is, one who has understanding, let him understand. The one who overcomes will not be harmed by the second death, that is, one who overcomes the Jews who are such in the circumcision of the flesh, not in spirit. ${ }^{57}$ By the second death, that is, the first death is of the flesh, the second, of hell.

13 And in olden days or Antipas, my faithful witness, was killed among you, where Satan dwells. How can this be, when before he says: You hold my name? He says to the good part: [You hold] my name, that is, you are 
Christian. Antipas my witness, that is, a famous martyr in that time. ${ }^{58}$ Where Satan dwells, that is, he speaks of the bad part of the church.

17 To the one who overcomes I shall give to him hidden manna. And I shall give him a white stone and on the stone [will be] written a new name which no one knows except the one who receives [it]. To the one who overcomes I shall give, that is, the one who overcomes the teaching of Balaam (Rev 2:14). Hidden manna, that is, the body of Christ, since he is the living bread which came down from heaven (John 6:51) just as the manna in the wilderness. ${ }^{59} \mathrm{He}$ says hidden because this manna concealed itself in the first manna. Or it is called hidden for this reason, because "the bread of life (John 6:35) is not given to all, for the one who eats unworthily eats and drinks damnation on himself (1 Cor 11:29)." ${ }^{60}$ Or in another way of interpreting the manna, the spiritual meaning is hidden by the literal. White stone, that is, "the body made white in baptism." "' And upon ${ }^{62}$ the stone a new name, that is, "the mystery of the Son of Man." ${ }^{63}$ Or the new name, the divine word against the heretics. ${ }^{64}$ Which no one knows, etc., that is, except the one who receives it in deed and in faith.

18 The Son of God, who has eyes as a flame of fire, and whose feet [are] like fine brass, says these things: 20 I have a few things against you: that you tolerate the woman Jezebel, who seduces my servants to fornicate and to eat things sacrificed to idols.

18 Eyes as a flame, that is, the saints, because people fear the face of a saint as fire. Feet like fine brass, that is, the saints tried in various temptations.

20 The woman Jezebel, which is interpreted as "flow of blood" or "where the dunghill is." ${ }^{65}$ She was the wife of Ahab, king of Israel, who stands as an example [of evil] ${ }^{66}$ for the church, ${ }^{67}$ who teaches the servants of God, that is, Christians, to fornicate and to worship idols.

26 The one who overcomes, 28 I shall give to him the morning star. That is, the one who overcomes Jezebel will be given the morning star, that is, lucid teaching. Or $\mathrm{Christ}^{68}$ who rose again in the morning will be given to him for help.

\section{Chapter 3}

4 You have a few names in Sardis which have not soiled their garments; for they walk before me in white garments. A few names in Sardis, that is, because there is a perfect part and an imperfect part there. Who have not soiled their garments, that is, their bodies. Who walk in white garments, that is, in bodies made white through baptism. ${ }^{69}$

7 The One who is holy and true, who holds the key of David, who opens 
and no one shuts, and who shuts and no one opens, says these things. That is, holy in forgiving, true in retribution. Who holds the key of David, that is, the power of the kingdom. Who opens, that is, [opens] divine mysteries. And no one, that is, Arius and other heretics, shuts. And who shuts, that is, the gate of hell ${ }^{70}$ against the saints, and no one, that is, [none] of the Jews and heretics and demons opens.

12 The one who overcomes, I shall make him a pillar in the temple of my God, and he will not go outside any longer. And I shall write upon it the name of my God and the name of the city of my God, of the new Jerusalem which comes down from heaven from my God, and my new name. The one who overcomes, that is, [who overcomes] the Jews in their circumcision of body and not spirit. ${ }^{71}$ I shall make him a pillar, that is, the character of a pillar is beautiful and straight and firm; so also a holy person ${ }^{72}$ in the church is beautiful in good works and straight in judgment and firm in the bearing of tribulation. And he will not go outside, that is, [outside] of the church to the synagogue of Satan. The name of my God, that is, Christian, ${ }^{73}$ from Christ. And the name of the city, "Ecclesiasticus," for, the church is the name of the city of God. Of the new, through baptism, Jerusalem, that is, the holy church which every day is born of God. ${ }^{74}$ Coming down from heaven, because its head is $\mathrm{Christ}^{75}$ who came down from heaven (John 3:13). A new name, that is, the Son of Man. ${ }^{76}$

14 The faithful and true witness, who is the beginning of the creation of God, says these things: 15-16 I know that you are lukewarm, neither cold nor hot. For this reason I am going to spew you from my mouth.

14 The beginning of the creation of God, that is, [the beginning] of every creature or church.

15 Cold, that is, the heathen or the sinner or the pauper; hot, that is, faithful or righteous or one doing charitable deeds. ${ }^{77}$ I would that you were cold! Why does he so will? Because it is the character of cold water, when it changes its coldness, it turns into hot water. But lukewarm water, since it does not turn into hot water, it turns back into cold water. So also are the heathen or sinners. ${ }^{78}$ When they change their state, they come into the heat of faith and righteousness. But lukewarm people, when they do not add faith or righteousness to their first state, they are turned back to unfaithfulness and unrighteousness and sins, and so they rot in the stench of sin.

16 I am going to spew, etc., that is, if you do not repent, you are cast out by my word into hell. ${ }^{79}$

17 You say: I am rich, that is, in almsgiving, and do not do (Matt 23:3). Wretched, that is, in almsgiving. Poor, you do not have true riches. Naked, 
that is, you who have not clothed yourself with Christ (Gal 3:27). Blind, because you have not anointed your eyes with the eye salve of the word of God. ${ }^{80}$

18 Buy gold, that is, the word of God ignited by the fire of the Holy Spirit, tried, that is, it does not have a stain. In white garments, that is, bodies made white through baptism. ${ }^{81}$

\section{Chapter 4}

$1 A$ door in heaven was opened to me, that is, Christ born in the church, ${ }^{82}$ who is the door of life. ${ }^{83}$ Or the door of penance.

2 Immediately I was in the Spirit, and behold a throne had been set up in heaven. 3 And the one who was sitting upon it was similar in appearance to jasper stone and sardonyx. And there was a rainbow around the throne similar to an emerald. 4 And around the throne twenty-four thrones, and upon the thrones twenty-four elders sitting in white garments and having golden crowns on their heads. 5 And from the throne proceeded lightning and voices and peals of thunder and seven burning lamps before the throne, which are the seven spirits of God. $\mathbf{6}$ And before the throne a glassy sea similar to crystal, etc.

2 A throne set up in heaven, that is, the church in itself. ${ }^{84}$ He who was sitting, "that is, Christ." 85

3 Similar in appearance to jasper stone, that is, a white stone. It signifies Christ having the glory of divinity. And sardonyx, that is, a red stone. It signifies Christ because of the blood of the passion. There was a rainbow around the throne. For a rainbow has a twofold color, blue and red. It signifies the church because of the water of baptism ${ }^{86}$ and the fire of the Holy Spirit who descended in fire, ${ }^{87}$ or because of the heat of penance and martyrdom. ${ }^{88}$ Or the rainbow signifies the covenant given to Noah in the sky that a flood of water or fire would not come upon the world. ${ }^{89}$ An emerald, that is, a white stone. It signifies the church for the brightness of its faith.

4 Twenty-four thrones signify the church which in the Old and New Testament was built upon the twelve patriarchs and the twelve apostles. ${ }^{90}$ White garments, holy bodies. Crowns on their head, the worthiness of their life, or wisdom in rulers.

5 Lightning and voices, the assertion and understanding of the public preaching in the church. Peals of thunder, the preaching of the punishments of hell.

6 Glassy sea, that is, baptism in the sight of the church, which is called "glassy" for its purity ${ }^{91}$ in that it does not have hypocrisy in its mouth or in its heart, as it is written: Let your Yes be Yes, and your No be 
No (Matt 5:37). Similar to crystal, which is easily broken and not easily restored. So also baptism is not restored.

And in the midst of the throne and around [it] four living creatures full of eyes in front and in back. 7 And the first living creature [was] similar to a lion, the second similar to a calf, the third has a face like a man, the fourth similar to an eagle. 8 And the four living creatures had six wings, and around and within they are full of eyes. And they had no rest day and night saying: Holy, holy, holy, Lord God of hosts, etc.

6 In the midst of the throne and around [it] four living creatures, that is, the four "Gospels in the midst of the church"92 [pointing] to the love of neighbor, and around [pointing] to the love of God who is everywhere. Full of eyes in front and in back, that is, they tell about the beginning and the end of the world, likewise about the past and the future. ${ }^{93}$

7 The first living creature, Mark, who first spoke about the voice of the lion saying: The voice of one crying (Mark 1:3). ${ }^{94}$ The second living creature, Luke, who first said: There was a certain priest, etc. (Luke 1:5); for it is customary for priests to offer a calf. The third living creature, Matthew, who first spoke about the genealogy of man saying: The book of the generation, etc. (Matt 1:1). ${ }^{95}$ The fourth living creature, John, flying in the heights toward divinity saying: In the beginning was, etc. (John 1:1). ${ }^{96}$

8 Six wings, that is, the twenty-four elders, for six wings of each of the four living creatures are twenty-four. ${ }^{97}$ Within and without ${ }^{98}$ full of eyes, that is, in history and its deeper meaning. ${ }^{99}$ Having no rest, as it is written: Pray without ceasing (1 Thess 5:17). Holy three times because of the Trinity. ${ }^{100}$

10 They cast down the crowns before the throne saying: You are worthy to receive glory and honor and power, because You have created all things. That is, they cast down their crowns: "whatever" goodness "the saints have, they attribute everything to God."101 Glory, that is, [the glory] of the resurrection; honor, [the honor] of divinity; power, [the power] of miraculous signs.

\section{Chapter 5}

1 And I saw in the right hand of the one sitting on the throne a book [written] inside and out, sealed with seven seals. 3 And no one was able to open the book, neither in heaven nor on earth nor under the earth.

1 I saw in the right hand, that is, the right hand of Christ is that by which he made and redeemed the world. A book [written] inside and out, sealed. The book "signifies the Old Testament." 102 Inside and out, that is, in history and its deeper meaning. ${ }^{103}$ Again, concerning the humanity and divinity of Christ. Seven seals, that is, the seven events which are primarily 
read about Christ, that is, the nativity, etc. Sealed in the Old [Testament] for this reason, since no one was able to know: Behold, a virgin will conceive in her womb, etc. (Isa 7:14) up to the time when Christ was born of the virgin. These are the seven events sealed in the Old Testament: ${ }^{104}$

Concerning the nativity of Christ, as it is [written]: Behold, a virgin will conceive in her womb, etc. (Isa 7:14). Christ opened it when he was born, as it is said: Today for us our Savior was born (Luke 2:11).

The second seal is about his baptism, as it is [written]: We have gone through fire and water, etc. (Ps 66:12). Christ opened it, as John [the Baptist] says: Behold, I ought to be baptized by you, etc. (Matt 3:14).

The third seal is about his passion, as [it is written]: Just as a sheep led to the slaughter, etc. (Isa 53:7). Christ opened it, as [it is written]: With his head bowed he gave up his spirit (John 19:30).

The fourth seal concerns his burial, as [it is written]: His burial will be honorable (Isa 11:10). Again: As one free among the dead (Ps 88:6). Christ opened it, as it is written: When Joseph had taken the body of Jesus, he wrapped it in a clean linen cloth (Matt 27:59).

The fifth seal is about his resurrection, as [it is written]: Rising, Lord, you will have mercy on Zion (Ps 102:14). Christ opened it, as the angel says: He is not here, for he has risen, etc. (Matt 28:6).

The sixth seal is about his ascension, as [it is written]: Sit at my right hand, etc. (Ps 110:1). Christ opened it, as the angel said: As you saw him going into heaven, etc. (Acts 1:11).

The seventh seal is about his coming, as it says: Our God will come openly (Ps 50:3). He opened it, as Peter says: The elements will burn with fire (2 Pet 3:12) in the coming of the Lord.

3 No one is able, neither in heaven nor on earth nor under the earth, to open the book, that is, no one in heaven since none of them took on flesh except Christ; no one on earth since no one is without sin; nor under the earth since no one was freed from hell until Christ rose from the dead.

5 One of the elders, that is, the order of the prophets consoles the church. ${ }^{105}$

\section{Chapter 6}

And 1 one of the four living creatures, that is, the order of teachers in the New Testament.

Here he opened the first seal. 2 A white horse, the Christian people, ${ }^{106}$ white through baptism. The one who sat upon it, that is, Christ. Holding a bow, that is, authority and the power of judgment. 
Indeed $\mathbf{4}$ a red horse, and the one who sat upon it, it was given to him to take peace from the earth, etc. The red horse, that is, the people of the persecutors, and the one who sat upon it, the devil. ${ }^{107}$

5 A black horse, and the one who sat upon it had a scale in his hand. The black horse, the people of the heretics who commit works of darkness (Rom 13:12). The one who sat upon it, the devil, holding a scale, that is, the likeness of equity in judgment. ${ }^{108}$

6 A quart of wheat for one denarius and three quarts of barley for a denarius, and do not harm the wine and oil. Quart, the name of a measurement. Isidore says: "A pint is the equivalent of two pounds, which doubled is called a quart, quadrupled is in Greek called a cenix." 109 Likewise Primasius says, "In the wheat and the barley he signifies the whole church, whether in the great or the least, or in the bishop and in the people; they have one price, that is, they have been redeemed by the blood of Christ." 110 Likewise "in the barley the apostles are prefigured, since the leftovers of the miracle of Christ had been twelve baskets, ${ }^{11}$ which are the body of bishops. And after the bishops seven baskets are mentioned ${ }^{112}$ which are the body of the sevenfold church." 113 In another way of interpreting it, quart of wheat, that is, the contemplative [part of the] church. For one denarius, that is, the unity of divinity, or the unity of the person in Christ from divinity and humanity. And three quarts of barley, that is, the active [part of the] church for one denarius. As we have said before, the contemplative [part of the] church is said to be one quart inasmuch as it has believed the unity of divinity, and for this reason the active [part of the] church is said to be three quarts inasmuch as it has believed the faith of the Trinity. But nevertheless the contemplative [part of the] church holds the faith of the Trinity and the active [part of the] church believes the unity of divinity. Do not harm the wine and the oil, that is: Wine is everyone who drinks the blood and wine of the gospel, and oil is everyone [in the] church who in baptism has received the oil, with which all kings and priests and prophets were anointed.

8 A pale horse, and the one who sat upon it, his name [was] death. And hell followed and power over four parts [of the earth] was given to him. Pale horse, false people, false brothers who are not white like the Christians, nor black like the heretics. His name [was] death, that is, the devil, about whom it says: Death, where is your sting? (1 Cor 15:55) because he has offered death to many, as Christ whose name is "life" 114 has offered life to others. ${ }^{115}$ Hell followed him, that is, heathen people followed the devil in deed and go lower into hell. [Power] over four parts ${ }^{116}$ [of the earth] was given to him, 
that is: Moreover, the whole earth is people, and they are divided into two parts, into "the people of God and the people of the devil." 117 Moreover, the people of the devil are divided into three parts, into persecutors and heretics and false brothers. These are the three parts over which the devil has power, that is, over the people of God in that he is always striking the church, so that she has a greater reward, and the devil has power over the other three parts which serve him.

9 And I saw under the altar the souls of those killed on account of the word of God. Under the altar, that is, under the exalted deed of martyrdom. Or under heaven ${ }^{118}$ because upon it spiritual sacrifices are offered by the church. Or under the altar, under the confession of faith. Or under the high commandment of Christ, because they were slain on account of the commandments of the Lord. Or under the church, because her children were slain under her. Or under the flesh of Christ, which was made from the earth, as he says to Moses: You will make for me an altar from the earth (Ex 20:24). Under that earth ${ }^{119}$ souls cry out, as it is written: The blood of your brother cries out to me from the earth (Gen 4:10). ${ }^{120}$

11 Robes to each, that is, the white [robe] signifies each person's merits. For he says that souls have a single beatitude until the Day of Judgment, and after the resurrection the saints will have two robes, that is, two beatitudes, that of soul and body. ${ }^{121}$

12 And I looked and a great earthquake occurred. And the sun became black as sackcloth, and the moon became as blood. 13 And the stars fell upon the earth as a fig tree loses its figs. 14 And heaven receded as a book rolled up, and every mountain and island were moved from their places. 15 And all the strong and the rich will hide in caves and rocks. $\mathbf{1 6}$ And they will say: Hide us and fall upon us on account of the wrath of the Lamb sitting upon the throne.

12 Earthquake, that is, a departure ${ }^{122}$ of the faithful away from the faith during the persecution of Antichrist. The sun became black, that is, Christian people [entering] into heresy or mourning. The moon as blood, that is, the church in the blood of martyrdom. ${ }^{123}$

13 The stars will fall, ${ }^{124}$ that is, those who are shining in the church ${ }^{125}$ will fall into denial [of Christ].

14 Heaven as a scroll rolled $u p$, that is: When a scroll is rolled up, you do not understand what is written in it. In the same way, the anguished church will be rolled up in the time of persecution, separated from people, so that the people will not be able ${ }^{126}$ to know the things which will be in it.

15 And those who are strong in faith and rich in good works, [will hide] in caves and rocks, that is, the mystical doctrines of Holy Scripture, or 
in the examples of Christ. In the mountains, in the heights of faith; in the rocks, in strong works.

\section{Chapter 7}

1 And after these things I saw four angels standing on the four corners of the earth holding the four winds of the earth, that they should not blow upon the earth or the sea and the trees. 2 And I saw an angel ascending from the rising of the sun having the seal of the living God. And he said to the angels to whom it was given to harm the earth and sea: 3 Do not harm the earth and sea and trees until we seal the servants of God on their foreheads. 4 And I heard the number of the sealed, one hundred and forty-four thousand sealed from every tribe of Israel. Twelve thousand from each tribe, except the tribe of Dan. ${ }^{127}$

1 The four angels and four winds are the same [thing], ${ }^{128}$ that is, the fourfold teaching of evil teachers, which contradicts the Gospel with its fourfold division. Moreover these angels are holding the winds, that is, evil teachers holding themselves back so that their teaching does not influence people when they see that they are conquered by divine power. Upon the earth, that is, upon earthly people. Upon the sea, that is, upon those profound in wisdom. Upon the trees, that is upon those who bring forth good fruit (Matt 7:17). In another way of interpreting it, four angels, that is, the church, which is fourfold because of the four Gospels. Holding the four winds, that is, the teaching of the devil, which is fourfold because it influences [hearers] against the teaching of the fourfold church.

2 I saw another angel, that is, Christ, from the rising of the sun, from the nativity of Christ, having the seal of the living God, that is: Because he is God no one was able to have this seal ${ }^{129}$ except the Son of God. Or the sign of the cross which the church has on its forehead.

3 Until we seal, that is, in baptism.

4 One hundred and forty-four thousand: By this finite number the infinite number of believers is signified. From the twelve tribes of the sons of Israel, that is, from the twelve tribes of believers who will believe the teaching of the twelve apostles. Concerning this it is said to these apostles: Judging the twelve tribes of Israel (Matt 19:28). ${ }^{130}$ Likewise Primasius says of the one hundred forty-four thousand: "For, by this mystical number is signified the innumerable multitude of the elect. A finite number is recognized for an infinite number, just as the circumference of the city ${ }^{131}$ is one hundred forty-four thousand cubits." ${ }^{132}$ And no one thinks that this is the number of infants who were killed by Herod. ${ }^{133}$ For what ignorant, unskilled person thinks that this is the number of infants from the tribe 
of Judah whom Herod killed, when all the names of the tribes are listed here ${ }^{134}$ And also the infants were killed only in Bethlehem of Judah. ${ }^{135}$ And Dan is not numbered here for this reason, because the Antichrist is born from that tribe. ${ }^{136}$ Some say that the one hundred and forty-four thousand will be the number of believers who will believe Enoch and Elijah in the time of Antichrist. ${ }^{137}$

14 They washed their robes in the blood of the Lamb, that is, the entire Catholic Church has washed its merits or its bodies in baptism or in the blood of the Lamb, "not, as some $e^{138}$ think," that these are "only martyrs, but the entire church. For, he did not say 'in their own blood' but in the blood of the Lamb, that is, in the grace of God through Christ." 139

\section{Chapter 8}

$\mathbf{1}$ There was silence in heaven for about half an hour. 2 And I saw seven angels, and seven trumpets were given to them.

1 Silence from the worship of idols when Christ came into the world. In heaven, in the church, for about half an hour, that is, because of the brevity of the New Testament in comparison with the Old Testament. [Or:] the length of time in the worship of idols. Again silence, that is, the church will rest from tribulations during the preaching of Enoch and Elijah ${ }^{140}$ about half an hour, because of the brevity of the time of Enoch and Elijah.

2 Seven angels, that is, the teachers of the sevenfold church because of the seven gifts of the Holy Spirit, ${ }^{141}$ or because of the seven steps (Ezek 40:22, 40:26) in the church. Seven trumpets, that is, Scripture, in which the sevenfold Spirit spoke, or in which seven [events] of Christ are read: his birth, baptism, etc. ${ }^{142}$

3 Another angel came and stood before the altar, having a golden censer. And much incense was given to him that he might offer [it] upon the golden altar. 5 And the angel filled the censer from the fire of the altar and cast it upon the earth. And great peals of thunder sounded.

3 Angel, that is, Christ. ${ }^{143}$ Before the altar, before the church. ${ }^{144}$ Censer, his body, ${ }^{145}$ parched in the passion and tried as gold in the fire of the passion. Incense, the prayers of the saints ${ }^{146}$ which Christ offers to the Father upon the golden altar, that is, upon his body or upon the church which is the body of Christ, tried in tribulations.

5 The angel took the censer, that is, Christ receives his cross from the fire of the altar, that is, from God, and cast it upon the earth, that is, he preached to earthly people.

7 The first angel sounded a trumpet, and great hail and snow mixed 
with blood followed, and was cast upon the earth. And a third part of the earth was burned. That is, the first order of teachers preached, and hail followed, that is, the weightiness of vengeance, mixed with blood, that is, mixed in a human, because a human preached the vengeance of God. And a third part of the earth was burned, that is, a third part of humans, because humans are divided into three parts: good teachers, good listeners, and those who are neither good teachers nor good listeners. ${ }^{147}$ These will be burned in vengeance, that is, the earthly and high and proud and carnal, as a third part of the earth and trees and grass, because flesh is grass (Isa 40:6). ${ }^{148}$

8 The second angel sounded a trumpet, and a great mountain burning with fire was cast into the sea. And a third part of the sea was turned into blood. 9 And a third part of the creatures which have souls died, and a third part of the birds died.

8 Great mountain, that is, the devil, burning with perpetual torments, was cast into the sea, into bitter, heathen people. ${ }^{149}$ And a third part, as we have said, who are neither teachers nor students were turned into blood, that is, were avenged with blood.

9 And a third part of the fish, that is, of the philosophers who have souls, that is, those who would have lived in good deeds if other evil people, with whom they agreed, had not prevented them. And a third part of the birds, that is, the astrologers or those who fly by human will.

10 The third angel sounded a trumpet, and a great star, burning as a torch, fell from heaven and fell upon a third part of the rivers. 11 And the name of the star was Wormwood, and a third part of the waters was turned into wormwood, and many died in the waters.

10 A great star fell, that is, the church of heresy ${ }^{150}$ fell from the Catholic Church. Great to indicate people of status. ${ }^{151}$ As a torch, that is, a torch is a piece of cut wood and has fire in the middle of it. As one who is wounded by it dies and burns, so one who consents to heretics has vengeance in the present and in the future. Fell upon the springs of the waters, that is, upon the princes of the people.

11 The name of the star was Wormwood for this reason: because the teaching of the church of heresy is bitter and deadly to souls.

12 The fourth angel sounded a trumpet, and a third part of the sun and a third part of the moon and a third part of the stars were stricken. And a part of them was darkened in the day and at night. 13 And I heard the sound of an eagle fying through the midst of heaven, saying: Woe, woe, woe to those dwelling on the earth.

12 A third part of the sun darkened, that is, the third part of the 
leadership in the church. And a third part of the moon, the lesser ones in the church, as we have said, who are neither teachers nor listeners. A third part of the stars, that is, those who are diverse in merits. ${ }^{152}$ Part of them was darkened in the day and at night, that is, a third part of the sun in the day and $a$ third part of the moon and stars in the night. "For this reason it was stricken, that is, given over to their own desires, ${ }^{153}$ so that as their sins become more abundant, it may be clearly revealed which is the part of Christ and which is the part of the devil." 154

13 The sound of an eagle, that is, the sound of the church which flies into the sublime by heavenly thoughts. Through the midst of heaven, that is, because the church is neither wholly celestial nor wholly earthly, because she has a body from the earth and heavenly association, as Paul says: Our association is in heaven (Phil 3:20). ${ }^{155}$ Or, the sound of an eagle, that is, the sound of the preaching of Christ in the midst of the church. Christ is called an eagle because of his ascension to heaven. Woe three times because of the three parts of the church.

\section{Chapter 9}

1 The fifth angel sounded a trumpet, and I saw that a star had fallen from heaven onto the earth; and the key to the bottomless pit was given to him. 2 And he opened the bottomless pit, and smoke from the pit arose. And the sun was darkened. 3 And locusts came forth from the smoke of the pit, and power was given to them as to the scorpions of the earth. $\mathbf{4}$ And it was commanded that they not harm the grass of the earth nor greenery nor tree, excepting only the people who do not have the seal of God on [their] foreheads. 5 And it was said to them that they should not kill them, but that they should be tormented five months.

1 I saw that a star had fallen from heaven, that is: The people of the sinners falls from lofty faith into denial of Christ. For, "the star and the pit and the abyss are people," as "David says: May the pit not shut its mouth on me (Ps 69:15)." ${ }^{156}$ The star receives the key to the abyss, that is, the people receive the power of opening and closing their heart. Or, the key to the bottomless pit, evil work. Indeed the pit is hell. ${ }^{157}$ Smoke of the pit, that is, the persecution of Antichrist.

2 The sun was darkened, that is, Christian people [were darkened] by sinners persecuting them. ${ }^{158}$

3 Locusts, that is, prattling heretics. ${ }^{159}$ As scorpions. For a scorpion kills with its head and tail. Thus, heretics kill souls with their head, public teaching, and with their tail when they encourage sins a little. Or it kills 
with the head, that is, with evil work, and kills with the tail, that is, with pride. ${ }^{160}$

4 Not harm the grass, that is, the subordinate church, greenery, that is, the higher ones, trees, those who have the fruit of good work. Seal on their foreheads, that is, baptism. Or it signifies the sign of the cross of Christ.

5 Five months, that is, five "years; for the torment was interrupted in the fifth year." 161

7 Like horses prepared for battle, that is, like the last persecutions ${ }^{162}$ in the time of Antichrist. And upon their heads crowns like gold, that is, in imitation of the twenty-four elders having golden crowns. ${ }^{163}$

8 And their hair [is] like that of women, and teeth like those of lions, and face of a man 9 and an iron breastplate. Hair of women, that is, many desires ${ }^{164}$ according to the likeness of a woman; teeth of lions, that is, strong teachers, for devouring souls; an iron breastplate, hard hearts and chests; face of a man since they imitate humanity ${ }^{165}$ so that they may deceive all the more. Sound of wings, that is, the noise of their evil teaching running against Christians as the sound of wings; and they run in unison.

10 And for five months 11 they have over them the king of the angels of the abyss, whose name in Hebrew is "Abaddon," but in Greek "Apollion," and in Latin "Exterminans." 12 One woe has passed, and behold two are coming.

10 "He said 'five months' for the whole time of the five-year persecution that happened principally in Africa." 166

11 Angel of the abyss, that is, the devil which in Hebrew is "Abaddon." Here the devil is named in three languages.

13 The sixth angel sounded a trumpet, and I heard a voice, one of the horns of the golden altar which is before the eyes of God. $\mathbf{1 4}$ And he said to the sixth angel: Loose the four angels who are bound in the river Euphrates. 15 And the four angels were loosed, they who had been prepared for the hour and day and month and year, that they should kill a third part of humanity. 16 And the number of the army of horsemen was twenty thousand times ten thousand.

13 The sixth angel, that is: The seven angels, which we have spoken of before, contain the whole span of time from the birth of the Lord up to the end of the world. Some say that each one [of the angels] is in part of the world at one [and the same] time, [an opinion] which we do not hold; but they were [sent] in consecutive order, and each one was distinguished in his own time. The sixth angel signifies the persecution of Antichrist; the seventh ${ }^{167}$ signifies the time which will be before the judgment, as in that passage: For, when people will say "Peace" and "Safety" (1 Thess 5:3). 
I heard one, that is, Christ, of the horns, that is, of the strong ones, of the golden altar, that is, the Catholic Church, because any other altar is not golden but is the church of evildoers (Ps 26:5) and of heresy. Before the eyes of God, that is, because of the other church of heresy which is not before the eyes of God, as it is said: For I do not know you (Matt 7:23).

14 And he said to the angel, that is, to the order of teachers: Loose the four angels, that is, "Preach!" because through preaching the angels are loosed for the persecution of the church. The four angels are said to be the devil with those who [bring about] ${ }^{168}$ four persecutions which happen through them in the four parts of the earth. Are bound, that is, from the time when Christ suffered, the devil has been bound, ${ }^{169}$ as the Lord says: No one is able to enter, etc (Matt 12:29; Mark 3:27). In the river Euphrates, that is, in sinful people who dash around throughout the whole world to persecute the church. And for this reason it is called the Euphrates, because of the flood of wickedness.

15 Who were prepared for the hour and day and month and year, that is, the time of the three and a half years of the persecution of Antichrist. ${ }^{170}$ That they should kill a third part of humanity, that is, they who are neither good teachers nor good listeners.

16 The number of the army of horsemen, that is, people who have as riders evil spirits. ${ }^{171}$ Twenty thousand times ten thousand, that is, the innumerable people of the heretics.

17 And I saw horses and those who were sitting upon them, having breastplates of fire and of hyacinth and of brimstone. And the heads of the horses [were] like those of lions, and from their mouth [came] fire and smoke and brimstone. The horses are the persecutors who are swift to do evil. Breastplates of fire, that is, hard hearts burning with the fire of evil desire. Hyacinth, pretending to please God who is in the blue heaven. Brimstone, putrid fire. It signifies those who are burning in their longing of sin. Heads like those of lions because they are fit for devouring souls. From their mouth smoke, that is: Just as smoke harms the eyes, so their teaching harms the saints.

\section{Chapter 10}

1 And I saw a strong angel coming down from heaven, clothed with a cloud. And a rainbow [was] on his head, and his face [was] as the sun, and his feet as pillars of fire. 2 And he had in his hand an open book. And he placed his right foot upon the sea and his left upon the earth. 3 And he roars like a lion, and seven peals of thunder spoke. $\mathbf{4}$ And I was going to write down their sounds. 
1 Another angel, that is, Christ, ${ }^{172}$ strong in giving aid to the church, coming down, that is, in the flesh, ${ }^{173}$ clothed with a cloud, that is, with a body. Or with the cloud of holy people, as it is said: These are they who fly as clouds (Isa 60:8). ${ }^{174}$ Rainbow on his head, the promise of perseverance to the holy church. ${ }^{175}$ On his head, in his divinity. Face as the sun, that is, the face of Christ, the righteous in the church, as in the passage: The righteous will shine like the sun, etc. (Matt 13:43). Feet as pillars of fire, that is, firm and strong in tribulation.

2 An open book in his hand, that is, the whole canon in his power. His right foot upon the sea, that is, the stronger ones in the church [are subject to] greater persecutions, left foot, the lesser and the weak [are subject to] earthly tribulations. ${ }^{176}$

3 Roars like a lion, because of the courage of the preaching of Christ. ${ }^{177}$ Seven peals of thunder spoke, that is, the teachers of the church [spoke] with the seven gifts of the Holy Spirit. ${ }^{178}$

4 I was going to write it down, that is, clearly. And the angel said to me: Seal up the things which the seven peals of thunder spoke, and do not write them down. Seal up, that is, write "through allegory lest the things written down be disclosed without concealment." 179 Do not write them down, that is, clearly "without concealment." 180

6 And he said to me: Time will be no more. 7 But in the days of the voice of the seventh angel, the mystery of God will be finished, that is, because in the last trumpet ${ }^{181}$ of the seventh angel whatever the prophets have prophesied about the Son of God and about the end of the world will be finished.

9 And he said to me: Take the open book and eat it, and it will make your stomach bitter, but in your mouth it will be sweet as honey. That is: Here it is said to John, in the person of the church, ${ }^{182}$ who is consuming the whole Scripture about the authority of Christ. Eat the book, that is, "ingest in your inward parts" 183 the word of God. It will make your stomach bitter, that is, because of the labor of fulfilling it, ${ }^{184}$ as it is written: Enter through the narrow gate (Matt 7:13). Stomach, that is, your soul. In your mouth it will be sweet as honey, that is, when you teach others.

\section{Chapter 11}

1 And there was given to me a reed similar to a rod, and he said: Measure the temple of God and the altar and those praying in it. 2 Moreover, the courtyard, which is outside the temple, leave out and do not measure it since it has been given to the nations, and they will trample the holy city for forty-two months. 3 And I shall send my two witnesses, and they will prophesy 
one thousand two hundred and sixty days clothed in sackcloth. 4 These are two olive trees and two candlesticks in the presence of God.

1 A reed, that is, divine wisdom, which is called a reed because with a reed [something] is written. Similar to a rod, because of correction since in wisdom there is discipline. Measure the temple of God, that is, judge the works of each person in the church from the wisdom of this book, so that [they are not judged] too little or too greatly, but by the measure of this rod, that is, [this rod] of wisdom. And the altar, that is, the high priests or the contemplative [part of the] church.

2 Moreover the courtyard, which is outside the temple, that is the church of heresy. ${ }^{185}$ The courtyard was empty just like those who are outside the church. ${ }^{186}$ Do not measure it, that is, do not teach those heretics, ${ }^{187}$ as [it is written]: Do not give what is holy to dogs (Matt 7:6). It has been given to the nations, that is, a part of the nations. They will trample the holy city, that is, the nations will trample the Catholic Church ${ }^{188}$ for forty-two months, that is, the whole time of Antichrist. ${ }^{189}$

3 Two witnesses, that is, Enoch and Elijah, ${ }^{190}$ will prophesy one thousand two hundred and sixty days, that is: "He spoke not [only] of the times of the last persecution, but of the future peace and the whole time from the passion of the Lord, since each time has just as many days," as some say. ${ }^{191}$ Clothed in sackcloth. He indicates the work of repentance.

4 Two olive trees and two candlesticks, both Elijah and Enoch.

7 And when they will have finished their testimony, the beast which ascends from the abyss will make war against them, and will overcome them and will kill them. 8 And their bodies will lie in the streets of the great city, which is called spiritually Sodom and Egypt, where also their Lord was crucified. 9 And all peoples and tongues will see [their bodies] for three and a half days. They will not allow their bodies to be put in tombs. 11 And after three and a half days the spirit of life entered into them, and they will stand upon their feet.

7 Beast which ascends, that is, the devil [ascends] from hell into the Antichrist. Will overcome them, Elijah and Enoch, through death, not by [causing them] to deny [Christ].

8 Of the great city, that is, of the whole world, which is called spiritually Sodom, that is, according to history, ${ }^{192}$ but for a similitude to the evil deeds of the residents of Sodom, and Egypt because of the "darkness" 193 of their sins and because of their ignorance.

9 For three and a half days, that is, for the three and a half years ${ }^{194}$ of the persecution of Antichrist. Or an infinite time from the birth of the Lord 
up to the end of the world is contained in this finite number. They will not allow their bodies [to be put] in tombs, that is, they will not allow monasteries to be built on the places in which their bodies have been buried. ${ }^{195}$ Or they will not allow [their] bodies [to be put] in tombs, that is, they will not allow them, after their death, to be [put] in the places in which [the dead] are buried throughout the world. ${ }^{196}$

11 The spirit of life entered into them, that is, according to the historical sense. Or they will rise again.

12 And I looked. They ascended in a cloud into heaven. 13 And in that hour also a great earthquake occurred, and a tenth part of the city fell, and seven thousand were killed there. $\mathbf{1 4}$ The second woe has passed and the third woe will come shortly.

12 They ascended in a cloud, as Paul says: "We shall be caught up in the clouds to meet Christ (1 Thess 4:17)." 197

13 A tenth part of the city fell, that is, from the beginning of the persecution up to the end of the world a tenth part of the church will fall into denial [of Christ]. Seven thousand, that is a finite [number] is mentioned for an infinite [number].${ }^{198} \mathrm{Or}$, a tenth part is said for this reason, because the church is tenfold because of the ten words of the Law, and sevenfold because of the seven steps (Ezek 40:22, 26) of the church.

\section{Chapter 12}

[11:19] The seventh angel sounded a trumpet, and the temple of God in heaven was opened. And the ark of the covenant was seen in his temple. 1 And there appeared in heaven a woman clothed with the sun, and the moon under her feet, and on her head a crown of twelve stars, 2 and having [a child] in her womb and giving birth.

19 The temple of God in heaven was opened, that is, the body of Christ was manifested in the church. And the ark, that is, Holy Scripture or the flesh of Christ.

1 Great sign, that is, the Word made flesh (John 1:14). [In heaven], in the church. A woman clothed with the sun, that is, the church defended by Christ in baptism and clothed by Christ in good works. The moon under her feet, that is, the church which is lower, ${ }^{199}$ subjected to the higher ranks. And on her head twelve stars, that is, on Christ, who is the head of the church, "twelve apostles." 200

2 And having [a child] in her womb, that is, [having] Christ in her heart.

3 And a great red dragon was seen in heaven, having seven heads and 
ten horns, and upon their heads seven diadems. $\mathbf{4}$ And his tail drew a third part of the stars of heaven.

3 Dragon, that is, the devil ${ }^{201}$ in the body of heretics. Red for the shedding of blood. Seven heads, that is, seven kings. Ten horns, that is, ten kingdoms. ${ }^{202}$ Seven diadems, that is, seven princes.

4 His tail, false prophets. ${ }^{203} \mathrm{~A}$ third part of the stars, that is, a third part of the church, ${ }^{204}$ as we have said above.

And the dragon stood before the woman who was about to give birth, and so that when she had given birth to a son he might devour him $\mathbf{5}$ who will rule with an iron rod. This was fulfilled in Herod, who wanted to kill Christ, after he had been born from Mary. ${ }^{205}$

And the son was caught up into heaven. $\mathbf{6}$ And the woman fled into the wilderness where they nourish her for one thousand two hundred and sixty days. That is, the son [was] caught up, Christ ascended into heaven. ${ }^{206}$ The woman fled, Mary into Egypt. ${ }^{207}$ Or the church will flee into the desert of Arabia ${ }^{208}$ in the time of Antichrist.

7 And a battle occurred in heaven, Michael and his angels fight with the dragon. 8 And the dragon will not prevail. 9 And he was cast forth on the earth, and his angels with him were cast into the lake of fire.

7 Michael, that is, Christ. For Michael is interpreted as "Who is like God," ${ }^{209}$ which pertains to Christ, who is like God the Father. And his angels, holy people ${ }^{210}$ who announce the truth. Dragon, that is, the devil. ${ }^{211}$ And his angels, bad heretical people who speak falsehood.

8 The devil will not prevail in opposing Christ, 9 but will be thrown out on the earth, that is, into earthly people, ${ }^{212}$ from heaven, from the high church.

14 And two wings of an eagle were given to the woman, that she might fly into the desert, where she is nourished for a time and times and half a time from the presence of the serpent. 15 And the serpent spewed from his mouth after the woman like a river, that he might sweep her away by the river. 16 And the earth helped the woman, and the earth opened up its mouth and absorbed the river.

14 The two wings of the woman, that is, "the two Testaments," ${ }^{13}$ the Old and New. Of an eagle, that is, Christ who ascended into heaven. Into the desert, that is, away from the morals of the devil. Time and times, etc., that is, the time of Antichrist. Or, in this certain number is contained the whole time from the birth of Christ up to the end of the world. ${ }^{214}$

15 The serpent spewed after the woman, that is, the devil sent persecution. ${ }^{215}$ Like a river, [said] for his abundance of malice. That he might sweep her into his body by the river, that is, by the persecution. 
16 The earth helped her. The earth, that is, the body of Christ, ${ }^{216}$ helped the church.

\section{Chapter 13}

1 And he stood upon the sand of the sea. And I saw a beast coming up out of the sea, having seven heads and ten horns, and upon his heads names of blasphemy.

And he stood upon the sand of the sea, that is, upon unbelieving people, who are called "sand" for this reason, because they are innumerable. Or for this reason: because they are not joined in harmony. And I saw a beast out of the sea, that is, a persecutor of the people out of the persecution. For, the beast and ${ }^{217}$ the sea are one, "as if he had said: 'I saw a beast coming out of the beast." ${ }^{218}$ Upon his ${ }^{219}$ heads names of blasphemy, that is, they say the souls of their dead kings go into other bodies after their death. ${ }^{220}$ Or, upon his heads names of blasphemy, that is, when they say that "their kings have been translated into heaven and are among the gods," ${ }^{221}$ so that after their deaths they are worshipped as gods.

2 And the beast which I saw was similar to a leopard, and his feet like those of a bear, and his mouth like that of a lion. And the dragon gave to him his power. 3 And one of his heads [was] as if slain in death. And his deadly wound was healed, and the whole earth marveled after the beast. 4 And they worshipped the dragon. $\mathbf{5}$ And power was given to him for forty-two months. $\mathbf{6}$ And he opened his mouth in blasphemies toward God and his name and his tabernacle and those who dwell in heaven. 7 And he will overcome all his saints, and power was given to him over every tribe and tongue and nation. 8 And all who dwell on the earth will worship him, whose names were not written in the Lamb's book of life, who was slain from the foundation of the world.

2 Was similar to a leopard, that is, on account of the variety of desires in wicked people. His feet like those of a bear, that is, they are twisted just like the understanding of his own twisted and depraved people. His mouth like that of a lion, that is, on account of the strength of his pride. And the dragon gave to him his power, that is, the devil gave power to Antichrist.

3 One of his heads slain, that is, the rank of princes. ${ }^{222}$ It is said: as if slain in death because they believe that the life of that [beast will return] after death; for this reason they are said to be "as if slain."

4 And they worshipped the dragon, that is, the dragon is the devil; for one who worships Antichrist, worships the devil in him.

5 Power was given to him, that is, he "was permitted by God" 223 so that those who have been approved may be manifest (1 Cor 11:19). 
A mouth speaking great things, that is, that he was born and suffered and rose again and is coming to judge the world.

6 Blasphemy toward God, that is, when he says that he is the Son of God, but nevertheless plots against the sons of God. And his tabernacle, that is, heaven or the church. ${ }^{224}$

7 And to overcome them, that is, [to overcome] their souls by denial and their bodies by death. Power was given to him over every tribe and tongue and nation, that is, because part of each tribe and tongue and nation will believe Antichrist. ${ }^{225}$

8 Who were not written in the Lamb's book of life, "that is, before the lamb, that is, the church, existed, it was sealed unto life" eternal on account of the knowledge of God. ${ }^{226}$ In another way of interpreting the Lamb's, that is, Christ's, because it was sealed in the providence of the Father that Christ would take on flesh. Who was slain from the foundation of the world, that is, because it was prophesied and prefigured from the foundation of the world that Christ would be slain. Or, the lamb was slain from the foundation of the world, that is, the church, as Cain slew Abel. ${ }^{227}$

11 And I saw another beast coming up out of the land, and he had horns similar to a lamb, and he spoke as a dragon. 12 And he exercised the power of the first beast. And whoever does not worship him will be killed. And he will make all those who dwell on the earth to worship the first beast, whose mortal wound was healed. 13 And he performs great signs, so that he makes fire to come down from heaven. 15 And it was granted to him to give life to the image of the beast, so that the image of the beast might speak. 16 And that he should cause all people to have a mark on the right hand or on their foreheads, 17 and that no one is able to buy or sell, unless he has the mark or the name of the beast or the number of his name. 18 Here is wisdom: one who has understanding calculates the number of the beast. For his number is six hundred and sixty-six.

11 I saw another beast coming up out of the land, that is, heretical people being born from other wicked people; for, the land and the beast are one. ${ }^{228}$ He had two horns, "that is, two testaments," 229 similar to a lamb, that is, because they say they are people of the true lamb, that is, [the people] of Christ. "For this reason the Lord says, Beware of the false prophets who come in sheep's clothing of sheep but inwardly are ravenous wolves (Matt 7:15)."230 Or, he spoke as a dragon, that is, when the evil that is within the heart proceeds out in the open. ${ }^{231}$

12 And he exercised the power of the first beast, that is, these two beasts are one body, wicked people and the people of the heretics. Or the people, 
who preside, exercise [power] because of the subjected people. Whose mortal wound was healed, that is, they think that he has life after death. Or when they think that their souls go into other bodies after their death.

13 He makes fire to come down from heaven onto the earth, that is, if this sign occurs before the eyes of people, it should not be denied. ${ }^{232} \mathrm{Or}$, fire from heaven, that is, retribution from the church because of his persecution. Onto the earth, onto earthly men agreeing with them..$^{233}$

14 That they should make an image of the beast, that is, that they might be the image of the beast ${ }^{234}$ and that they would be the body of the devil.

15 And that he might give life to the image of the beast, that is, that he might give teaching to those who make the [image of] the beast. Or, that he might give baptism in the likeness of that [baptism] of the church, because through baptism the Spirit descends upon the church. Whoever does not worship the image of the beast or does not have his mark on [his] forehead or on [his] right hand will be killed, that is, one who does not believe or who does not imitate the people believing in the false prophets, having the likeness of the name of Christ on their hand, that is, in their deeds, or on their forehead.

Mark, that is, a monogram, as Christians have the sign of the cross. For a mark is a sign ${ }^{235}$ or monogram, either a name or the number of the letters of a name.

18 Here is wisdom, that is: for, although we have said it is a beast, nevertheless it is a man. But the Spirit says "beast." For it is the number of a man, that is, the number of the name of a man, not the number of the name of a beast. And the number of his name is six hundred and sixty-six or six hundred and sixteen in other books. ${ }^{236}$ Moreover the name which has that number is "Christ," which is written in Greek letters, that is, chi $(\chi)$ and psi $(\psi)$. Moreover $\psi$ [is the combination of] pi $(\pi)$ and sigma (cc)..$^{237}$ Moreover, over chi is found the number six hundred; and over psi, one hundred; and sigma, two hundred. The number ten cannot be over psi, so then another Greek letter is given in the place of [psi], that is, iota ( 1 ) which signifies ten, and for this reason is able to be put in the place of [psi], as long as they are of the same language. And sigma does not signify the number six, because the Greeks do not have a letter which signifies six. Therefore, in the place of that letter which is called sigma is put a "final sigma," 238 the character of the number among the Greeks [written] in this manner $\cdot \zeta$, which signifies six. This interpretation is not easy, because what is a name is not a number, and what is a number is not a name. So then let us make one letter which can be both a name and a number. That 
is, for the letter chi, with which the name begins, there can be a name, and this letter is called a monogram. For "mono" in Greek means "one"239 in Latin; gramma means "letter." For what reason is a monogram put in the Apocalypse, when it is not found in the book literally? ${ }^{240}$ For this reason, because the angel said: One who has understanding calculates the number of the beast. This is the "monogram," [put] in this way: $\mathbb{R}$. For in it is found chi $(\chi)$ and rho ( $\rho)$ or psi $(\psi)$ and sigma (c), that is, xps. As Jerome says, the name of Christ is written with a chi, a rho, and a sigma. ${ }^{241}$

Likewise in other books it is found thus: six hundred and sixty-six. However, the name which this number has is "tietan," and for this reason this name speaks of Antichrist, in whom the devil will be entirely. For "tietan" in Greek is interpreted "sun," which fits Antichrist, in whom the devil will be. And concerning the devil it is said: Who transforms himself into an angel of light (2 Cor 11:14). ${ }^{242}$ This is the number of that name, because the tau signifies three hundred, and the iota ten, and the eta five, and again the tau three hundred, and the alpha one, and the nu fifty. Together they make the number six hundred and sixty-six. ${ }^{243}$ Suitably is it said of Antichrist, who pretends that he fulfills the four gospels and the two testaments and the ten commandments of the law. ${ }^{244}$ For, this number six hundred and sixty-six possesses meaning through the [numbers] ten and six. It is spoken correctly of Antichrist, who says that he fulfills the ten commandments of the law, and that he made the world in six days, and that he gave to man the ten senses of the soul and body, and that he made the world [to last] through six ages.

Likewise: "Here is wisdom: one who has understanding calculates the number of the beast, etc., until six hundred and sixty-six. Moreover, one who will have the mark or the name of the beast or the number of his name is one [and the same]. Therefore, let us work out a number, so that in that number we may recognize the name and the mark. His number is six hundred and sixty-six, which we write according to the [letters of] the Greeks. For it is the name, ANTEMOS, ${ }^{245}$ which name, as I have said, calculated in Greek equals six hundred and sixty-six. Moreover, 'antemos' is interpreted 'contrary to honor,' 246 as if he were to say: Antichrist, for whom an 'anathema ${ }^{247}$ is fitting, is contrary to the honor which belongs to God alone." 248

"Likewise: There is another name which equals the sum of the same number, namely ARHOUME, ${ }^{249}$ which together make the same number. However, this name is interpreted 'I deny, ${ }^{\text {'250 }}$ which is fitting for Antichrist, that is, the name of denial, as the name of faithfulness is fitting for 
Christ. Moreover, whether 'contrary to honor' or 'I deny,' both can rightly be referred to Antichrist. Moreover, because he says: For it is the number of a man, surely [it is the number] of Christ, which Antichrist desires to receive through false imitation." 251

Likewise: Moreover, "CHRISTEI 252 in the genitive case, whose seven letters, calculated according to his number, finish near that number of days which will then be in the persecution of Antichrist, that is, one thousand two hundred and twenty-five days. In his [i.e. Christ's] likeness Adversity fraudulently presents himself. ${ }^{253}$ In this mark, that is, in the monogram, which is drawn in this way: $\mathbb{R}$, are one thousand two hundred and twenty[-five]. When in a sum the whole name of Christ, C R I S T E $\mathrm{I},{ }^{254}$ is enclosed, in it, as I have said, are [the numbers] one thousand two hundred and twenty-five."255

Likewise: "The name of Adam, using Greek letters, fulfills the number forty-six in this way: A D A M ${ }^{256}$ which make forty-six, although the number forty-six itself is broken down in this way: K O U A A R A G I H T A C C Z, ${ }^{257}$ which together make the number one thousand two hundred and twenty-five, which we said above is in the monogram." 258

17 Likewise, a recapitulation: That no one may be able to sell or buy, unless he has the name of the beast or the number of his name. "Just as the church hands down the symbol ${ }^{259}$ for the benefit of our salvation," 260 so that it is not allowable for any Christian to engage in commerce except with one who has the symbol of faith, so too Antichrist will make this likeness, as it is said: No one can enter into the house, etc. (Matt 12:29)

18 Here is wisdom, etc., that is, so that he may be recognized by the number of the name, and understanding, that is, for what reason it happened [that] he wrote this name. Or, wisdom and understanding is the same thing, as the mark and name and number are used synonymously. This is the reason for the name written for Antichrist: just as there is the symbol of faith and the cross of Christ on the foreheads of Christians that they may be recognized as servants of Christ, just as there was [a mark] on the forehead or on the hand of Cain, ${ }^{261}$ as Jerome says, so that he might be recognized, ${ }^{262}$ so also Antichrist makes [a mark], as he is thought to be Christ. In this likeness let us make the number, so that we may recognize the name and the mark from the number.

His number is six hundred and sixty-six, which we write according to the [letters of] the Greeks for this reason: because this work was written to the Greeks of Asia. ${ }^{263}$ Likewise "it should be known that Scripture does not announce this number by only one definition. In another place in this 
book, power was given to the dragon for forty-two months (Rev 11:2). In another place: I will send my two witnesses, so that they may prophesy one thousand two hundred and sixty days (Rev 11:3)." ${ }^{264}$ Likewise in Daniel: a time and times and half a time (Dan 7:25, 12:7), that is, three and a half years. Likewise one thousand two hundred and ninety days is found there (Dan 12:11); likewise one thousand two hundred and ninety-five days. ${ }^{265}$ In this it is shown that Christ did not want to divulge clearly to human knowledge the day of judgment or of his coming, as he said to the apostles: It is not yours to know the times or seasons, etc. (Acts 1:7). ${ }^{266}$ Likewise: how this mark is named, Isidore says "crisenon." 267

This alone is put so that something may be known from the opinion of each one. THUS FAR CONCERNING THE MONOGRAM.

\section{Chapter 14}

1 And I looked, and behold, an angel was standing upon Mount Zion and with him one hundred and forty-four thousand having his name and the name of the Father written on their foreheads. 3 And they were singing a new song before the four living creatures and the twenty-four elders, who were redeemed from the earth. 4 And they have not been defiled with women, for they are virgins.

1 An angel was standing upon Mount Zion, that is, Christ will come upon Mount Zion for judgment. ${ }^{268}$ Having his name and the name of his Father, etc., that is, the sign of the cross of Jesus Christ, the Son of the living God (Matt 16:16).

3 A new song, that is, all the faithful who have not been corrupted by heretical teaching, and they will sing forever with the Lamb, rejoicing about the incorruption of the flesh. Who were redeemed from the earth, that is, Christ redeemed them by his blood ${ }^{269}$ from among earthly people.

4 Who follow the Lamb, that is, [follow his] example. ${ }^{270}$

6 I saw another angel flying through the midst of heaven, having the gospel, that is, the order of those who preach the gospel through "the midst of the church." ${ }^{271}$

8 And another angel said: Babylon the Great has fallen, etc., that is, he recapitulates the times of the persecutions. ${ }^{272}$ Babylon, that is, the people of the devil, because Babylon is interpreted as "confusion." 273

15 And another angel went out of the temple, who was sitting upon a white cloud. 16 And he thrust forth his sickle on the earth, and the earth was reaped. 19 And he gathered the clusters of vine.

15 That is: The angel, Christ, went out of the temple, out of heaven, who was sitting upon a white cloud, upon the church whitened in baptism. 
16 And he thrust forth a sickle onto the earth, that is, retribution onto earthly people.

19 And he gathered clusters, that is, he cut off sinners from wickedness. And he cast the clusters into the winepress ${ }^{274}$ of the wrath of God. 20 And the winepress was trodden outside the city. And blood flowed out of the winepress up to the bridles of horses for [a distance of] one thousand and sixty stadia. ${ }^{275}$

19 He cast the clusters into the winepress of the wrath of God, that is, he sent persecutors into the world, which should suitably receive the wrath of God.

20 And the winepress was trodden outside the city, that is, the world [was trodden] through the shedding of blood outside the church, since [they who are of the world] are not among the number of the saints of the church. Blood flowed out, that is, retribution ${ }^{276}$ going to and fro throughout the whole world, up to the bridles of horses, that is, up to the teachers of the peoples. ${ }^{277}$ For [a distance of] one thousand and sixty stadia, that is, throughout the breadth of the whole world. ${ }^{278} \mathrm{He}$ puts a finite [number] for the infinite.

\section{Chapter 15}

1 And I saw another sign in heaven, seven angels having the seven last plagues. 2 And I saw a glassy sea mixed with fire, and angels holding harps 3 singing the song of Moses, the servant of God.

1 I saw another sign in heaven, that is, the orders of persecutors in the church unto the end of the world.

2 Glassy sea mixed with fire, that is, baptism ${ }^{279}$ mixed with the fire of the Holy Spirit, because the Holy Spirit is given in baptism. Or baptism mixed with the fire of persecution. ${ }^{280}$ Harps, "the hearts of those praising God."281

3 The song of Moses, that is, the song of the Lamb, this is, "each Testament." 282

5 And I saw, the temple of the tabernacle of the testimony in heaven was opened. 6 And the seven angels having the plagues went out of the temple, clothed in clean linen, girded with golden girdles. 7 And one of the four living creatures [approached], and gave [them] seven golden bowls full of the wrath of God. $\mathbf{8}$ And the temple was filled with smoke.

5 The "temple" and "tabernacle" and "heaven" are names of the church, ${ }^{283}$ because the vessels in her are the Holy Scriptures.

6 Seven angels, that is, the fullness of the household of Christ versus the fullness of the household of the devil. Clothed in clean linen, that is, 
[clothed] with Christ. ${ }^{284}$ Clean, that is, [cleansed] from sin. And girded with golden girdles, that is, with spiritual chastity.

7 One of the four living creatures, etc., that is, Christ, when he takes on the form of any one of the four living creatures, ${ }^{285}$ he teaches the church. Seven golden bowls, that is, the teaching of the sevenfold Spirit of the wrath of God, that is, because he tells of the wrath of God.

8 The temple was filled with smoke, that is, the church was filled with compunction of heart. ${ }^{286}$

\section{Chapter 16}

2 And I looked, and the first angel poured out his bowl on the earth, and a grievous wound came [upon it.] 3 The second poured out a bowl into the sea, and it became blood. 4 The third poured out a bowl into the rivers and springs of water, and they became blood. 8 The fourth poured out a bowl into the sun, 9 and the heat burned people, and they blasphemed our God. 10 The fifth poured out a bowl upon the seat of the beast, and his throne became full of darkness. 11 And they gnawed their tongues. 12 The sixth poured out a bowl into the great river Euphrates, and dried up its water, that a way for the kings from the east may be prepared. 13 And I saw three unclean spirits [go forth] from the mouth of the dragon and of the beast and of the false prophet 14 in the manner offrogs; for, they are spirits of demons performing signs for all the kings of the whole earth, to gather them for war on the great day of the Lord. 15 And the Lord comes as a thief. Blessed is the one who watches and guards his garments, lest he be naked. 16 And he gathered them unto the place which is called in Hebrew "Armageddon." 17 The seventh angel poured out his bowl into the air, and a loud voice went out of the temple from the throne. 18 And flashes of lightning and a great earthquake occurred. 19 And the great city was divided into three parts, and the cities of the nations fell. And Babylon came into remembrance before God, to give to her the cup of the wine of the wrath of God. 20 And every island fled, and the mountains were not found. 21 And hail like a hundredweight came down from heaven upon people, and they blasphemed God.

2 A grievous wound, that is, [the wound] of sin in the soul ${ }^{287}$ which does not receive Catholic teaching.

3 Into the sea, into bitter ${ }^{288}$ and inconsistent people. Blood, that is, [the blood] of the judgment.

4 Into the rivers, that is, into wicked people and those not consistent in good. Springs, that is, the rulers of the wicked.

8 Into the sun, that is, into the church of heretics.

9 They burned, that is, because of the greatness of the judgment. 
They blasphemed the name of the Lord, that is, in "calling themselves children of God," although they are "full of indulgence in sins." 289

10 His throne full of darkness, that is, in comparison to the Catholic Church.

11 They gnawed their tongues, that is, "harming themselves while blaspheming God." 290

12 Into the great river Euphrates, "that is, into wicked people" 291 running about throughout the whole world to persecute the church. Dried up its waters, that is, its persecution was extinguished. A way for the kings, that is, for each holy person of the church, ${ }^{292}$ from the east, that is, from the resurrection of Christ.

13 The dragon and the beast is the devil, or a wicked ruler and the wicked people subject to him. Of the false prophet, that is, the order of heretics. Three spirits on account of the three aforementioned persons, although it "is one" wicked "spirit." 293

14 In the manner of frogs, that is, [they are described as such] because of the uncleanness and vain speech ${ }^{294}$ of heretics. They will perform signs, as: Did we not cast out demons in your name? (Matt 7:22). For kings, that is, the people of the kingdom of the devil. To gather for war, "not that they are gathered from the whole world into one place, but each nation in its own place" 295 fought with united intention against the church of God. On the great day of the Lord, that is, "from the passion of the Lord" ${ }^{296}$ until the end of the world is called one day.

15 As a thief, that is, for the extinguishing of the persecutions in the judgment. One who watches, that is, [the righteous person clothed] in righteousness. Garments, that is, good virtues.

16 Armageddon, that is: It is interpreted as "rising up in former things, ${ }^{297}$ that is, the saints liberated from the persecution.

17 Into the air, that is, into insincere ${ }^{298}$ people. "Out of the temple, that is, out of the church." 299

19 The city was divided into three parts, that is: All people which are under heaven are divided into three: into teachers; into students; and they who are neither teachers nor students. ${ }^{300}$ The cities of the nations fell, that is, those not consistent in the truth will be humbled in the judgment. Babylon the great, that is, the total confusion ${ }^{301}$ of the body of the devil.

20 Every island fled, that is, every church ${ }^{302}$ [fled] for fear of denying [Christ]. All the mountains, that is, the saints not following the beast.

21 Hail like a hundredweight, that is, [described as such because of] the greatness of the retribution. 


\section{Chapter 17}

3 And I saw a woman, a harlot, sitting upon a scarlet beast, full of names of blasphemy, having seven heads and ten horns. $\mathbf{4}$ And the woman was wrapped in purple and scarlet and gold and precious stone and pearls, holding a golden chalice in her hand, the price of the uncleanness of fornication. 5 And her name written: Mystery, Babylon the Great, mother of fornications. $\mathbf{6}$ And I saw the woman drunk from the blood of the holy martyrs. 7 And the angel said to me: I shall tell you the mystery of the woman and of the beast which carries her, which has seven heads and ten horns. 8 The beast, which you saw, was and is not and is going to arise from the abyss and will go into destruction. And all those dwelling on the earth, whose names were not written in the book of life, will wonder at her. 9 The seven heads are seven mountains upon which the woman is sitting; and they are seven kings. 10 Two ${ }^{303}$ have fallen; one is; another has not yet come, and when he comes, it is necessary for him to remain a short time. 11 And the beast which was and is not, is the eighth himself, and is from the seven. 12 And the ten horns [are] ten kings, who have not yet received a kingdom, but [have received] authority as if they are kings. And they will receive [authority] for one hour after the beast. 13 These will have one mind and the power of the beast. 14 These will fight with the Lamb. 18 And the woman which you saw is the great city which has dominion over the kings of the earth.

3 I saw a woman, that is, the woman and the beast are one. ${ }^{304}$ The wicked people is a beast on account of its cruelty; the woman [is called] a harlot on account of her indulgent will in evil. Scarlet, for the shedding of blood. ${ }^{305}$ Full of names of blasphemy, on account of some among the Jews, some among the heretics, and some among the heathen.

4 The woman was wrapped in purple, etc. All these things are worldly decorations, in which worldly men adorn themselves. A golden chalice in her hand, that is, the fullness of the will, [shown] in her deeds.

5 Name written on the forehead, that is, because in her appearance the diligence of a Christian person is shown; but the name written on her forehead "is hypocrisy, because on the outside she appears righteous to men (Matt 23:28)." 306 Mystery. She has the clothing of a Christian, but within is a ravenous wolf. ${ }^{307}$

6 I saw the woman drunk from the blood, etc., that is, [I saw] the church of the persecutors.

8 Going to arise from the abyss, that is, the devil from the wicked people. ${ }^{308}$

9 "Five have fallen; one is; another has not yet come, that is, "Gaius 
Julius Caesar, the first" emperor, "the second, Augustus, under whom" Christ "was born, ${ }^{309}$ the third Tiberius, under whom he suffered, the fourth Claudius, under whom the famine in the Acts of the Apostles took place, ${ }^{310}$ the fifth Galba, the sixth Nero, the seventh Otho, about whom he said, 'He has not yet come, it is necessary for him to remain a short time,' that is, in a figure of the revealed Antichrist; for," Otho "reigned for three months and six days," 311 and Antichrist will reign for three years and six months.

11 And is the eighth himself, because throughout the whole New [Testament] there is "the eighth." And it is from the seven, that is, because throughout the whole Old [Testament] there was "the seventh." In another manner of interpreting it: Is the eighth, in number, according to history. ${ }^{312}$ And is from seven, that is, they have one body.

12 Who have not yet received a kingdom, that is, until Antichrist comes. "As if kings, that is, because those, who oppose the kingdom of Christ, reign as if in dreams." 313 For one hour, that is, for the shortness of this age, or because the end of the world is as the last hour (1 John 2:18). After the beast, that is, of the body, and they are similar to him in morals. ${ }^{314}$ But [will receive] authority, that is, the devil will hand over the authority of the beast to Antichrist.

\section{Chapter 18}

1 And after these things I saw another angel coming down from heaven, and the earth was illumined by his brightness, that is, Christ, ${ }^{315}$ as is said: In your light we shall see light (Ps 36:9).

2 Babylon the Great has fallen, has fallen, that is, the city of this world has fallen in unfaithfulness and in judgment.

6 And render to her double according to her works; in the cup which she has mixed, mix for her double, 7 and to the degree she gloried in delights, give her that much torment. Double, that is, Christ is speaking to his angels, ${ }^{316}$ as it is [written]: In what measure you have measured, etc. (Matt 7:2). He says double, that is, here and in the future.

21 And a strong angel took up a stone like a millstone, and cast it into the sea, and said: With this violence Babylon the great will be cast. 22 And she will no longer be found. And merchants will no longer be in her, neither gold nor silver, neither paintings ${ }^{317}$ nor songs, etc. A strong angel, that is, Christ. $A$ stone, that is, the devil, who is hard and who does not turn in repentance. Into the sea, that is, into hell. With this violence Babylon will be cast, that is, the whole world will be cast into perdition. And she will no longer be found, 
that is, whatever is worldly will no longer be seen. Merchants and gold and silver, etc., that is, the lovers of the world and its delight will be no more. ${ }^{318}$

\section{Chapter 19} Lamb.

9 Blessed are they who have been invited to the marriage supper of the

The marriage supper of the Lamb, that is, the body and blood of Christ or the Old and New Testament in the joining of Christ and the church in the New Testament.

10 See that you do not do this. I am a fellow servant of you and of your brothers having the testimony of Jesus. For the testimony of Jesus [is] the spirit of prophecy.

See that you do not do this, etc. "Why is it that before the coming of Christ, ${ }^{319}$ the angels are worshipped by men and they are silent, but afterward refuse to be worshipped, except that after they perceived our nature, which formerly they looked down upon, as having been raised above ${ }^{320}$ themselves, they tremble at having once seen it ranked beneath them? And they have no longer dared to look down as beneath themselves and weak that which they venerate even above themselves in the King of heaven. Nor did they, who worship the God-man above themselves, disdain to have man as their companion." 321

Having the testimony of Jesus, that is: The one who has the testimony of Jesus is he who testifies of Jesus to people. The spirit of prophecy is the testimony of Jesus, that is, because the message ${ }^{322}$ of the prophets is said to be the whole canon of the Old and New Testament, which testifies of Jesus.

11 And I saw heaven opened, and behold a white horse, and he who was sitting upon it. 12 And his eyes [were] as a flame of fire, and on his head [were] many diadems. Having a name written, which no one knows except he himself, 13 and having a robe sprinkled with blood. 14 And the armies which are in heaven followed him on white horses, clothed in linen. 15 And from his mouth was proceeding a sharp two-edged sword. And he will rule the nations with an iron rod, and he treads the winepress. 16 And he has on his robe and on his thigh: King of kings.

11 Heaven opened, that is, the church was opened to receive God. A white horse, that is, the body of Christ ${ }^{323}$ or Christian people. He who was sitting upon it, that is, God.

12 His eyes [were] as a flame of fire, that is, those wise ones with the testimonies of the Scriptures with which they kindle and enlighten the hearts of the faithful. On his head [were] many diadems, that is, in his 
divinity [were] many saints who adorn Christ. Having a name written, that is, the mystery of the Son of Man, namely, that one person is God and man. Which no one knows except he himself, that is, except Christ and the church, which is his body. ${ }^{324}$

13 A robe sprinkled with blood, that is, his flesh ${ }^{325}$ whose blood was shed on the cross.

14 And the armies which are in heaven, etc., that is, the saints who are in the church follow Christ in bodies [made] white ${ }^{326}$ through baptism.

15 And from his mouth a sharp two-edged sword, that is, the sword of the word rendering judgment over the body and the soul, ${ }^{327}$ both here and in the future. He will rule with an iron rod, that is, in the hardness of the power of the kingdom. He will tread the winepress, that is, wicked people in whom the wine of pleasure dwells.

16 On [his] robe a name written, that is, the name preached in the church. On his thigh, that is, in his flesh. Or in the people of marriage according to the historical sense. Or in the teachers who give birth to others in faith and in baptism.

17 And I saw an angel standing on the sun, saying to the birds which were flying through heaven: 18 Come to the supper of the Lamb, that you may eat the flesh of kings and of horses and of those sitting on them.

17 I saw an angel, that is, Christ, on the sun, "in the church," 328 as it is said: On the sun he placed, etc. (Ps 19:4). Saying to all the birds, that is, to all those who fly to heavenly thought when disturbed by persecution.

18 Come to the supper of the Lamb, that is, to the whole canon of the Old and New Testament. That you may eat the flesh of kings and of horses, that is, that you may be filled when you see vengeance upon them. ${ }^{329}$ And the flesh of horses, that is, of persecutors. And of those sitting upon them, that is, of wicked princes.

19 And I saw the beast making war against him who was sitting on the white horse, that is, the beast is the impious city. Or, the devil fights against Christ. ${ }^{330}$

\section{Chapter 20}

1 And I saw an angel coming down from heaven holding the key of the abyss. 2 And with a chain he bound the dragon in the abyss for a thousand years. 3 And after the thousand years he was loosed for a short time.

1 An angel, that is, "Christ in his first coming." ${ }^{31}$ The key of the abyss, that is, the power of hell, that is, of wicked people. ${ }^{332}$

2 He bound the dragon in the abyss for a thousand years, that is, Christ 
bound the devil among wicked men throughout the entire New Testament [age].

3 He was loosed for a short time, that is, for three and a half [years] ${ }^{333}$ "in the time of Antichrist." 334

4 And I saw thrones and those who sat upon them. Judgment was given. They who did not worship the beast or his image nor received the mark on [their] foreheads or on their hands, these reigned with Christ for a thousand years. 5 And the rest of the dead did not live until the thousand years were finished.

4 I saw thrones, that is, many churches in the whole world, and those who sat upon them, that is, people who have greater authority. ${ }^{335}$ Judgment was given to them, that is, judgment through the wisdom of the Scriptures. Concerning the beast, the mark, and the rest, it was spoken about before. Reigned for a thousand years, that is, in the church in the present ${ }^{336}$ through the entire New Testament [age].

5 The dead did not live, that is, they who are dead in sins (Eph 2:1) did not live in the truth.

This is the first resurrection, that is, the initial one, to live with Christ.

6 In these the second death has no power, that is, the death of punishment.

7 And when the thousand years will be finished, Satan also will be loosed from his prison. 8 And he will deceive the nations which are upon the four corners of the earth, Gog and Magog. He will gather [them] to war, whose number [is] as the sand of the sea. 9 And fire from heaven will descend and will devour them. 10 And the devil who deceives them will be cast into the lake of fire, where both the beast and the false prophet [are].

7 Satan will be loosed from prison, that is, the devil will be loosed from sinful people, where only he still rules. But at that time he will rule not only over the wicked, but also over the saints, especially in the time of Antichrist.

8 Gog is interpreted as "covering," that is, the people of the heretics who have covered over their iniquity. Magog is interpreted as "uncovered," that is, the heathen who practice their iniquity openly. ${ }^{337}$

11 And I saw a white throne, and the one who was sitting upon it, from whose face heaven and earth fled. And no place was found by them. 12 And I saw opened books, and another book was opened, which is [the book] of life. And the dead were judged from the things which had been written in the books according to their deeds. 13 And the sea gave up its dead. And death and hell will devour the dead. 14 And hell and death were cast [into] the lake of fire. 15 And one who was not written in the book of life. 
11 I saw a white throne, here [it means] the chorus of the saints on the Day of Judgment. And the one sitting upon it, that is, Christ. The earth fled, that is, from the form in which it is, ${ }^{338}$ as it is said: I create new heavens and a new earth, and the former things will not be in [my] memory (Isa 65:17). And a place was not found by them, that is, a place which would defend them. Or, the place of their prior form.

12 The books were opened, that is, [the books] of "the remembrance of our deeds." ${ }^{39}$ And another book, that is, the book of divine knowledge, in which are the people who have been foreknown before the foundation of the world (1 Pet 1:20). ${ }^{340}$ Which is the book of life, as it is said: I am the way and the life and the truth (John 14:6)

13 The sea gave up its dead, that is, the world gave up its worldly people. Death, that is, the entire people of the devil. Hell, that is, everyone who has been destined to go into hell.

\section{Chapter 21}

10 And I saw the city, Jerusalem, coming down from heaven from God. 11 And its brilliance [was] as a stone of jasper and as crystal. 12 And it had a high wall having twelve gates, and on the gates twelve angels, ${ }^{341}$ and the names of the twelve tribes of the sons of Israel inscribed. 13 And on the east three gates, and on the north three gates, and on the west three gates, and on the south three gates. 14 And the wall of the city had twelve foundations, and on them the names of the twelve apostles. 15 And the one who was speaking with me had a golden measuring reed, that he might measure the city and the gates and the wall. $\mathbf{1 6}$ And the city was built in a square, and its length [was] as long as its width. And he measured the city with the reed for twelve thousand stadia. [Its] length and width and height are equal. 17 And he measured its wall: one hundred and forty-four cubits in the measure of a man, which is that of an angel. 18 And the walls of that city were from the stone of jasper, but the city itself [was] of pure gold like clear glass. 19 The foundations of the wall of the city were adorned with every precious stone. These are the stones: jasper, sapphire, chalcedony, emerald, 20 sardonyx, sardion, chrysolite, beryl, topaz, chrysophrase, hyacinth, [and] amethyst. 21 And the twelve gates are twelve pearls, and the streets of the city [are] pure gold like clear glass. 22 And I did not see a temple in it; for, its temple is our Lord and the Lamb. 23 And the city has no need of the sun or moon to shine on it; for the glory of God has illumined it. $\mathbf{2 4}$ And all brought their glory into it. 25 And its gates will not be closed throughout the day, and there will be no night there. 27 And nothing abominable and false entered it, but only those who have been written in the Lamb's book of life. ${ }^{342}$ 
10 I saw the new Jerusalem coming down from heaven, that is, the church, ${ }^{343}$ new through baptism. Coming down from heaven, that is, from the other church, the heavenly one, ${ }^{344}$ as it is said: Every good gift [comes down from heaven] (James 1:17). In another way of interpreting it, Jerusalem coming down from heaven, that is, the church built by Christ, having holy teaching given by God, as it is said: All wisdom is from God (Sir 1:1).

11 Its brilliance [was] as a stone of jasper, that is, having the glory the Lord had on the mount. ${ }^{345}$ As a stone of jasper, that is, the work of the church is similar to Christ, because she has learned his examples, as it is said: Be perfect as I am perfect (Matt 5:48); again: Let your light shine, etc. (Matt 5:16).

12 It had a high wall, that is, a wall of faith or all the many faithful. High for her elevation in good works, as it is written: Our association is in the heavens (Phil 3:20). Twelve gates, that is, the twelve apostles or the bish$\mathrm{ops}^{346}$ in the church. Twelve angels, that is, the successors of the apostles or those subject to the bishops in the church. The names of the twelve tribes of the sons of Israel we understand as the things which are in the power of the apostles or of the bishops, as it is said: You will sit upon twelve thrones, etc. (Matt 19:28).

14 The wall and the foundation of the apostles, ${ }^{347}$ the bishops who are in the church, as [it is said]: You are Peter and upon this rock, etc. (Matt 16:18).

13 On the east three gates, that is, faith in the Trinity ${ }^{348}$ from childhood ${ }^{349}$ because through faith one enters in the church. On the north three gates, that is, faith in the Trinity is proven in tribulation. ${ }^{350}$ On the south three gates, that is, wisdom, because in the wise is found a firm faith in the Trinity. ${ }^{351}$ On the west three gates, that is, to old age, because faith in the Trinity is especially confirmed among the elderly and in death. ${ }^{352}$

15 The one who was speaking with me, that is, the order of teachers, which speaks with the church under them. Had a golden reed, that is, divine wisdom, ${ }^{353}$ that he might measure the city, that is, that he might teach the Catholic Church.

16 The square city indicates the steadfastness of the church in good works, as it is said: Be steadfast, etc. (1 Cor 15:58). Or [it indicates] those steadfast in the teaching of the four Gospels. The length of the city, that is, the eternal life of the church in the future. Its width, that is, the breadth of charity ${ }^{354}$ in the church, as it is said [. . .]. ${ }^{355}$ For twelve [thousand] sta$\mathrm{dia}$, that is, the order of teachers teaches the church through the teaching of the twelve apostles. [Its] length and width and height are equal, that 
is, perseverance in good [works] and charity and faith are alike in the church.

17 The wall of the city: one hundred and forty-four cubits, that is: This number, however, is fitting to the people of God, who are strong in the faith [present] in the church, and who are numbered at one hundred and forty-four thousand. ${ }^{356}$ And the order of teachers measures, that is, teaches, this people from its wisdom.

The measure of man, that is: The men ${ }^{357}$ are the teachers who teach the church. Which is that of an angel, that is: Although the teachers are men, nevertheless they have angelic teaching and wisdom.

18 And its walls are [made] from the stone of jasper, that is, from Christ. The city itself [is] pure gold, that is, the church, which is golden and pure, is tried through the fire of tribulation (1 Pet 1:7), ${ }^{358}$ that it may be pure and shining. Like glass, on account of baptism.

19 With every precious stone, that is, with every perfect work.

21 And the twelve gates are twelve pearls, because "in each apostle is Christ, the precious pearl," ${ }^{359}$ as it is said: The kingdom of heaven is like a man [seeking] good pearls, etc. (Matt 13:45). The streets of the city, "that is, all the people of the church." ${ }^{360}$

22 For, our Lord is the temple of that city, that is: For, "the church is in God and God is in the church. The lamb and the city are the church." ${ }^{61}$

23 [The city] has no need of the sun and moon, that is, "the church" does not rule "by the elements of" this "world (Gal 4:3, Col 2:20), but by Christ, the eternal sun." 362 Or, the church in the future has no need of the present sun. "For, the glory of God has illumined it, as [he himself said]: I am the light of this world, etc. (John 8:12)." 363 The Lamb, that is, Christ, as [it is said]: Behold the Lamb of God (John 1:29, 1:36).

24 All the kings of the earth brought their glory to it, that is, the kings who rule over earthly and worldly people will bring to God their glory, that is, chastity and humility, etc.

25 And its gates will not be closed, that is, the gates of repentance will not be closed to those who wish to enter into the church of God. Throughout the day, that is, through Christ. There will be no night, that is, the night of ignorance or of $\sin .^{364}$

27 Nothing abominable entered it, as it is [written]: Lord, who will dwell in your tabernacle? up to The one who enters without stain (Ps 14:1-2). But only those who have been written in the Lamb's book of life, that is, those whom Christ foreknew to have grace. 


\section{Chapter 22}

1 And he showed me a river of the water of life shining as crystal, going out from the throne of God and of the Lamb, 2 and in the midst of its street, on each side of the river the tree of life, bearing twelve [kinds of] fruits, each yielding its fruit throughout the twelve months. And the leaves of the tree [were] for the healing of the nations. 3 And the entire curse will be no more. 4 And his servants were serving him, and his name [was] written on their foreheads.

1 A river, that is, "the fountain of baptism"365 or the fountain of knowledge. ${ }^{366}$ From the throne, that is, from the church.

2 In the midst of the street, that is, "in the midst of the church." ${ }^{367} \mathrm{On}$ each side of the river the tree of life, that is, "the cross of Christ," ${ }^{368}$ which before baptism was prefigured and prophesied in the old law, and after baptism was fulfilled ${ }^{369}$ in the new law. Bearing twelve [kinds of] fruits, that is, "through the teaching of the twelve apostles"; for, "the cross of Christ bears fruit in" 370 each month. The leaves of the tree, that is, the teaching of the suffering of the cross.

3 And the entire curse, that is, the $\sin ^{371}$ of Adam, will be no more. This is the end [of the discussion] concerning the city.

10 Do not seal up the words of the prophecy of this book. How can this be, since he said earlier: Seal up the words of this book [Rev 10:4]? The [answer] is: whatever is sealed and stamped is saved; for, it is as if he had said: The words of this book are sealed up for unbelievers; do not seal them up for believers. ${ }^{372}$

14 Blessed are they who keep their robes, so that their power may be in the tree of life. Robes, that is, works. Power in the tree of life, that is, the saints through the cross of Christ have power to supplant vices.

18 If anyone adds to these things, God will add upon him the plagues written in this book. 19 And if anyone takes away from the words of the book of this prophecy, God will take away his part from the tree of life, that is, not those who simply add or take away, "who say what they believe," ${ }^{773}$ but those who add and take away by the choice of their mind in an effort to complete $\mathrm{it},{ }^{374}$ and because they want to please everyone.

IT ENDS HERE. 


\section{NOTES}

${ }^{1}$ Cf. Jerome, Chronicle, 192.1-5; On Illustrious Men, 9.6, FC 100:20; Primasius of Hadrumetum, Commentary on the Apocalypse, prologue, CCSL 92:6, 19-20.

${ }^{2}$ Cf. Primasius of Hadrumetum, Commentary on the Apocalypse, prologue, CCSL 92:6, 20-25.

${ }^{3}$ Eusebius of Caesarea, Ecclesiastical History, 6.25, 9; Jerome, On Illustrious Men, 9, FC 100:19-20.

${ }^{4}$ Isidore of Seville, Chronicle, 2.259-63. Gryson, editor of the Latin edition, and the present translator, were unable to locate this opinion in the works of Gregory the Great.

${ }^{5}$ Jerome, Letter 53.9 quoted freely; NPNF, 2nd ser., 6:102.

${ }^{6}$ Isidore of Seville, Etymologies, 6.2, 49, PL 82:235. Cf. Pseudo-Jerome, Handbook on the Apocalypse of the Apostle John, on Rev 1:1.

7 That is, in visions.

${ }^{8}$ Victorinus of Pettau, Commentaries on the Apocalypse, on Rev 10:11, CSEL 49:92-93.

${ }^{9}$ Primasius of Hadrumetum, Commentary on the Apocalypse, prologue, CCSL 92:6-7.

${ }^{10}$ Cf. 1 Cor 13:12: "We see now through a glass in a dark manner."

${ }^{11}$ Cf. Pseudo-Jerome, Handbook on the Apocalypse of the Apostle John, on Rev 1:2.

${ }^{12} \mathrm{Cf}$. Bede, Exposition of the Apocalypse, on Rev 1:3, trans. Weinrich, 115.

${ }^{13}$ Cf. Pseudo-Jerome, Handbook on the Apocalypse of the Apostle John, on Rev 1:3.

${ }^{14}$ Primasius of Hadrumetum, Commentary on the Apocalypse, prologue, CCSL 92:7.

${ }^{15}$ Cf. Isa 11:2-3. Cf. Pseudo-Jerome, Handbook on the Apocalypse of the Apostle John, on $\operatorname{Rev} 1: 4$.

${ }^{16}$ Pseudo-Bede, On Luke, 50.

${ }^{17}$ Caesarius of Arles, Exposition of the Apocalypse of Saint John, preface, trans. Weinrich, 63 .

${ }^{18} \mathrm{Cf}$. Bede, Exposition of the Apocalypse, on Rev 1:4, trans. Weinrich, 115.

${ }^{19}$ Cf. Tyconius, Exposition of the Apocalypse, on Rev 4:4-6, 7:11, 7:17, 16:17, CCSL 107A:131, 149, 151, 201. Gryson, who reconstructed Tyconius's Exposition of the Apocalypse (CCSL 107A), was unable to reconstruct Tyconius's comments on Rev 1:1-11. However, because of the parallels here on Rev 1:4-5 with comments of Caesarius and Bede on the same verses, it is very likely that some of these comments derived from Tyconius on Rev 1:4-5. According to Mackay, ("Early Christian Millenarianist Interpretation of the Two Witnesses in John's Apocalypse 11:3-13,” 241), Bede did not have access to Caesarius. Therefore, "these two writers may be treated as independent witnesses of the text of Tyconius."

${ }^{20}$ Cf. 1 Tim 6:13; Caesarius of Arles, Exposition of the Apocalypse of Saint John, preface, trans. Weinrich, 63.

${ }^{21}$ Cf. Pseudo-Jerome, Handbook on the Apocalypse of the Apostle John, on Rev 1:5.

${ }^{22}$ Lat. saecula saeculorum or "forever and ever," but I have translated it literally because of the comments on it in the next line.

${ }^{23}$ Jerome, Letter 26.4. The manuscript has sinoita, but Gryson provides a correction.

${ }^{24}$ Jerome, On Hebrew Names, Apoc, PL 23:902; Cf. Bede, Exposition of the Apocalypse, on Rev 3:14, trans. Weinrich, 123.

${ }^{25}$ Cf. Augustine, On the Gospel of John, 39.8, NPNF, 1st ser., 7:224.

${ }^{26}$ Cf. Matt 24:29-30.

${ }^{27}$ When the verse was quoted above, the personal pronoun for "him" (eum) was used, 
but here the reflexive $s e$ is used. Hence, the alternate comment about mourning over themselves.

${ }^{28}$ Lat. iniciavit and consumavit, literally "began" and "consummated."

${ }^{29}$ Cf. Donatus, Orthography, Art of Grammar, CCCM 40D:23, 394-96.

${ }^{30}$ Lat. vindicat meaning "vindicates."

${ }^{31}$ Isidore of Seville, Etymologies, 1.3, 9, PL 82:76-77.

${ }^{32}$ Cf. 2 Cor 4:16.

${ }^{33}$ Cf. Isa 11:2-3.

${ }^{34}$ The author's quotation of this verse above did not include the word "Son."

${ }^{35}$ The Latin here is pudere (from pudor, meaning "modesty") instead of podere.

${ }^{36}$ Cf. Pseudo-Jerome, Handbook on the Apocalypse of the Apostle John, on Rev 1:13.

${ }^{37}$ Cf. Victorinus of Pettau, Commentaries on the Apocalypse, on Rev 1:13, CSEL 49:22-23.

${ }^{38}$ Cf. Victorinus of Pettau, Commentaries on the Apocalypse, on Rev 1:14, CSEL 49:20-21.

${ }^{39}$ Here the noun is in the plural flammae, which differs from when the author quoted the verse above in the singular flamma.

${ }^{40}$ Anonymous, Commentary on the Catholic Epistles, on 1 Pet 3:12, CCSL 108B:33.

${ }^{41}$ The edition reads nos consideramus or "we examine," but this verb was often used impersonally, giving it the passive meaning "we are examined." See Lewis and Short, Latin Dictionary, 218. Interestingly, a note in a second hand in the Paris manuscript reads nos considerat or "He examines us."

${ }^{42}$ Cf. Victorinus of Pettau, Commentaries on the Apocalypse, on Rev 1:15, CSEL 49:26-27; Pseudo-Jerome, Handbook on the Apocalypse of the Apostle John, on Rev 1:15.

${ }^{43}$ Cf. Eph 6:17.

${ }^{44}$ Cf. Heb 4:12; Pseudo-Jerome, Handbook on the Apocalypse of the Apostle John, on Rev 1:16.

${ }^{45}$ Lat. theorica. This word, which will appear several times later in the commentary (cf. on Rev $6: 6 ; 11: 1$ ), usually means the contemplative part of the church, e.g., cloistered monastics, as contrasted with the active part of the church, or the actualis. The theoreticalactualis contrast was a feature of early Hiberno-Latin exegesis. See the introduction to this volume.

${ }^{46}$ Cf. Pseudo-Jerome, Handbook on the Apocalypse of the Apostle John, on Rev 1:17.

${ }^{47}$ The Latin here, mortuus, should probably be mortis in the genitive, as he quoted it in the verse above: Habeo claves mortis, "I have the keys of death."

${ }^{48}$ He may be referring to the ancient schismatic Novatianists or Donatists, who held that restoration through repentance was impossible for certain sins like adultery, murder, and apostasy.

${ }^{49}$ Cf. Matt 13:12; Tyconius, Exposition of the Apocalypse, on Rev 2:5, CCSL 107A:114.

${ }^{50}$ Cf. Acts 6:5.

${ }^{51}$ Lat. fluxi. Cf. Jerome, On Hebrew Names, Apoc, PL 23:857, which gives effluxio as an alternative reading for effusio.

${ }_{52}$ Tyconius, Exposition of the Apocalypse, on Rev 2:7. CCSL 107A:114-15.

${ }^{53}$ Tyconius, Exposition of the Apocalypse, on Rev 2:7. CCSL 107A:115.

${ }^{54}$ The church finds comfort in the Lord's prediction that the tribulation she will endure will be of limited duration.

${ }^{55}$ Numbers greater in quantity are derivatives of the numbers one through ten. 
${ }^{56}$ Cf. Pseudo-Jerome, Handbook on the Apocalypse of the Apostle John, on Rev 2:10; Origen, Homilies on the Leviticus, homily 3, FC 83:65.

${ }^{57}$ Cf. Eph 2:11; Rom 2:29.

${ }^{58}$ Cf. Bede, Exposition of the Apocalypse, on Rev 2:13, trans. Weinrich, 119.

${ }^{59}$ Cf. Tyconius, Exposition of the Apocalypse, on Rev 2:17, CCSL 107A:119.

${ }^{60}$ Tyconius, Exposition of the Apocalypse, on Rev 2:17, CCSL 107A:119.

${ }^{61}$ Tyconius, Exposition of the Apocalypse, on Rev 2:17, CCSL 107A:119.

${ }^{62}$ Lat. super (upon) here, but in (on) when the author quotes the verse above.

${ }^{63}$ Tyconius, Exposition of the Apocalypse, on Rev 2:17. CCSL 107A:119.

${ }^{64}$ Cf. Jerome, Epistle 18b, PL 22:373.

${ }^{65}$ Jerome, On Hebrew Names, Apoc, PL 23:857. Or perhaps "Where is the dunghill?" Cf. Pseudo-Jerome, Handbook on the Apocalypse of the Apostle John, on Rev 2:10; Bede, Exposition of the Apocalypse, on Rev 2:20, trans. Weinrich, 120.

${ }^{66}$ Lat. malae was supplied in a second hand in the Munich manuscript.

${ }^{67}$ Lat. quae tenet figuram ecclesiae or perhaps "who contains a figure of the church."

${ }^{68}$ Tyconius, Exposition of the Apocalypse, on Rev 2:28, CCSL 107A:123.

${ }^{69}$ Cf. Tyconius, Exposition of the Apocalypse, on Rev 2:17, CCSL 107A:119.

${ }^{70}$ Cf. Matt 16:18; Pseudo-Jerome, Handbook on the Apocalypse of the Apostle John, on Rev 3:7.

${ }^{71}$ Cf. Rom 2:28-29.

${ }^{72}$ Cf. Pseudo-Jerome, Handbook on the Apocalypse of the Apostle John, on Rev 3:12.

${ }^{73}$ Cf. Bede, Exposition of the Apocalypse, on Rev 3:12, trans. Weinrich, 123.

${ }^{74} \mathrm{Cf}$. Tyconius, Exposition of the Apocalypse, on Rev 3:12, CCSL 107A:127; John 1:13.

${ }^{75}$ Cf. Eph 5:23.

${ }^{76}$ Cf. Tyconius, Exposition of the Apocalypse, on Rev 3:12, CCSL 107A:127.

${ }^{77}$ Cf. Pseudo-Jerome, Handbook on the Apocalypse of the Apostle John, on Rev 3:15.

${ }^{78}$ Cf. Pseudo-Jerome, Handbook on the Apocalypse of the Apostle John, on Rev 3:15.

${ }^{79}$ Cf. Matt 25:41.

${ }^{80}$ Cf. Augustine, Tractates on the Gospel of John, 2.16, NPNF, 1st ser., 7:18; PseudoJerome, Handbook on the Apocalypse of the Apostle John, on Rev 3:18.

${ }^{81} \mathrm{Cf}$. Tyconius, Exposition of the Apocalypse, on Rev 2:17, CCSL 107A:119.

${ }^{82}$ Cf. Pseudo-Jerome, Handbook on the Apocalypse of the Apostle John, on Rev 4:1.

${ }^{83}$ Cf. John 10:9; Tyconius, Exposition of the Apocalypse, on Rev 4:1, CCSL 107A:129.

${ }^{84}$ Meaning, both the throne and heaven are symbols of the church.

${ }^{85}$ Tyconius, Exposition of the Apocalypse, on Rev 4:2, CCSL 107A:130; Cf. PseudoJerome, Handbook on the Apocalypse of the Apostle John, on Rev 4:2.

${ }^{86}$ Cf. Pseudo-Jerome, Handbook on the Apocalypse of the Apostle John, on Rev 4:3.

${ }^{87}$ Cf. Acts 2:3.

${ }^{88}$ Cf. Pseudo-Jerome, Handbook on the Apocalypse of the Apostle John, on Rev 4:3.

${ }^{89}$ Cf. Gen 9:12-17; Victorinus of Pettau, Commentaries on the Apocalypse, 4.3, CSEL 49:48-49.

${ }^{90}$ Cf. Victorinus of Pettau, Commentaries on the Apocalypse, 4.5, CSEL 49:56-57; Apringius of Beja, Explanation of the Apocalypse, on Rev 4:4, CCSL 107:61.

${ }^{91}$ Cf. Apringius of Beja, Explanation of the Apocalypse, on Rev 4:6. CCSL 107:62.

${ }^{92}$ Tyconius, Exposition of the Apocalypse, on Rev 4:6, CCSL 107A:131. Cf. Victorinus of Pettau, Commentaries on the Apocalypse, on Rev 4:7-8, CSEL 49:48-49; Pseudo-Jerome, Handbook on the Apocalypse of the Apostle John, on Rev 4:6. 
${ }^{93}$ For this last comment about past and future, cf. Tyconius, Exposition of the Apocalypse, on Rev 4:6, CCSL 107A:132; Apringius of Beja, Explanation of the Apocalypse, on Rev 4:6, CCSL 107:62.

${ }^{94}$ Cf. Apringius of Beja, Explanation of the Apocalypse, on Rev 4:7, CCSL 107:62, whereas Victorinus on Rev 4:4 sees it as a symbol of the Gospel of John.

${ }^{95}$ For his comments about the second and third living creature, cf. Victorinus of Pettau, Commentaries on the Apocalypse, 4.4, CSEL 49:50-51; Apringius of Beja, Explanation of the Apocalypse, on Rev 4:7. CCSL 107:63.

${ }^{96}$ Cf. Victorinus of Pettau, Commentaries on the Apocalypse, 4.4, CSEL 49:52-53; Apringius of Beja, Explanation of the Apocalypse, on Rev 4:7, CCSL 107:63.

${ }^{97}$ Cf. Tyconius, Exposition of the Apocalypse, on Rev 4:8, CCSL 107A:133.

${ }^{98}$ Here the Latin is intus et foris, whereas the verse cited above reads in circuitu et intus.

${ }^{99}$ Here the author is speaking about the interpretation of Scripture, the literal or historical understanding (i.e., the eyes without) and the deeper, spiritual sense (i.e., the eyes within).

${ }^{100}$ Cf. Apringius of Beja, Explanation of the Apocalypse, on Rev 4:8, CCSL 107:64.

${ }^{101}$ Tyconius, Exposition of the Apocalypse, on Rev 4:8, CCSL 107A:133.

102 Jerome, Commentary on the Apocalypse, on Rev 5:1, CSEL 49:61; Cf. Apringius of Beja, Explanation of the Apocalypse, on Rev 5:1, CCSL 107:65-66.

${ }^{103}$ See the author's comments on Rev 4:8.

${ }^{104}$ For the interpretation, previous to The Reference Bible, of the opening of the seven seals as seven events in the life of Christ, see Hilary of Poitiers, Commentary upon the Psalms, prologue, CSEL 22:7; Apringius of Beja, Explanation of the Apocalypse, on Rev 5:1, in Seven Seals, ed. Gumerlock, 27; and pseudo-Alcuin, On the Seven Seals, in Seven Seals, ed. Gumerlock, 30-32.

${ }^{105}$ Cf. Tyconius, Exposition of the Apocalypse, on Rev 5:5, CCSL 107A:134.

${ }^{106} \mathrm{Cf}$. Caesarius of Arles, Exposition of the Apocalypse of Saint John, homily 5, where he says the white horse represents the church; trans. Weinrich, 72.

${ }^{107}$ Cf. Caesarius of Arles, Exposition of the Apocalypse of Saint John, homily 5, trans. Weinrich, 72.

${ }^{108}$ Cf. Caesarius of Arles, Exposition of the Apocalypse of Saint John, homilies 5 and 6, trans. Weinrich, 72-73.

${ }^{109}$ Isidore of Seville, Etymologies, 16.26.

${ }_{110}$ Primasius of Hadrumetum, Commentary on the Apocalypse, on Rev 6:6, CCSL 92:95-96, from Tyconius, Exposition of the Apocalypse, on Rev 6:6, CCSL 107A:138-39.

${ }^{111}$ Cf. Matt 14:20.

${ }^{112}$ Cf. Matt 15:37.

${ }^{113}$ Tyconius, Exposition of the Apocalypse, on Rev 6:6, CCSL 107A:139.

${ }^{114}$ Cf. John 14:6.

${ }^{115}$ For the contrast between the devil's name as "death" and Christ's name as "life," cf. Tyconius, Exposition of the Apocalypse, on Rev 6:8, CCSL 107A:141.

${ }^{116}$ Other Old Latin versions of Scripture of the African group, such as that of Tyconius and Primasius of Hadrumetum, had "a fourth part."

${ }^{117}$ Tyconius, Exposition of the Apocalypse, on Rev 6:8, CCSL 107A:140.

${ }^{118}$ Cf. Victorinus of Pettau, Commentaries on the Apocalypse, 6.4, CSEL 49:72-73.

119 Cf. Victorinus of Pettau, Commentaries on the Apocalypse, 6.4, CSEL 49:72-73, trans. Weinrich, 11. 
${ }^{120}$ Cf. Tyconius, Exposition of the Apocalypse, on Rev 6:9, CCSL 107A:142.

${ }^{121}$ Gregory the Great, Moral Teaching on Job, 35.14, 25, PL 76:762-63, 79:1111-12. Cf. Bede, Exposition of the Apocalypse, on Rev 6:11, trans. Weinrich, 130. Gregory and Bede cited as support Isa 61:7: "They will possess a double portion in their own land."

${ }^{122}$ Lat. mutatio, meaning a "change."

${ }^{123}$ Cf. Bede, Exposition of the Apocalypse, on Rev 6:12, trans. Weinrich, 131.

${ }^{124}$ Here the author uses the future tense, cadent, whereas when he quoted the passage above, he used the verb form in the perfect tense, ceciderunt, or "fell." Perhaps it indicates that he was familiar with different versions of Scripture or that he believed the historic fulfillment of the vision would take place in the future.

${ }^{125}$ Cf. Bede, Exposition of the Apocalypse, on Rev 6:12, trans. Weinrich, 131: "those who shine as heavenly figures in the church"

${ }^{126}$ Gryson's edition has the verb in the imperfect poterant, but I have followed MS M which reads poterint.

${ }^{127}$ Cf. Rev 7:5-8.

${ }^{128}$ Cf. Tyconius, Exposition of the Apocalypse, on Rev 7:1, CCSL 107A:146.

${ }^{129}$ Lat. hoc signum facere. Or perhaps "to make this sign" of sealing. Or perhaps "to do this sign" if it is an allusion to John $3: 2$.

${ }^{130}$ Cf. Tyconius, Exposition of the Apocalypse, on Rev 7:9-10, CCSL 107A:149.

${ }^{131}$ The New Jerusalem. Cf. Rev 21:17.

${ }_{132}$ Primasius of Hadrumetum, Commentary on the Apocalypse, on Rev 7:4, CCSL 92:108.

${ }^{133}$ This view was held by the community from which the apocryphal Revelation of Stephen was authored. See James, Apocryphal New Testament, 565.

${ }^{134}$ Cf. Tyconius, Exposition of the Apocalypse, on Rev 7:9-10, CCSL 107A:149; Primasius of Hadrumetum, Commentary on the Apocalypse, on Rev 7:5-8, CCSL 92:110.

${ }^{135}$ Cf. Matt 2:16.

${ }^{136}$ Cf. Pseudo-Jerome, Handbook on the Apocalypse of the Apostle John, on Rev 7:4; Bede, Exposition of the Apocalypse, on Rev 7:5, trans. Weinrich, 133. This belief was based upon Gen 49:17 and Jer 8:16, and was the view of Irenaeus of Lyons (Against Heresies, 5.30.2, ANF 1:559) and Hippolytus of Rome (On Christ and the Antichrist, 15, ANF 5:207). Quodvultdeus of Carthage, Theodoret of Cyrus, and Gregory the Great also expressed this view. See Huchedé, History of Antichrist, 15; and Hill, "Antichrist from the Tribe of Dan."

${ }^{137}$ Such as Victorinus of Pettau, Commentaries on the Apocalypse, on Rev 7:2, CSEL 49:82-83, trans. Weinrich, 12.

${ }^{138}$ For example, Cyprian of Carthage, who cited Rev 7:14 in relationship to the benefits of martyrdom in Ad Quirinum, 16 (ANF 5:538) and cited Rev 7:14 in Ad Fortunatum (ANF 5:505), calling them "the assembly of Christian martyrs."

${ }^{139}$ Tyconius, Exposition of the Apocalypse, on Rev 7:13-14, CCSL 107A:150.

${ }^{140}$ For Tyconius (107A:152) this represents eternal rest, and for Jerome (On Daniel, 4.12.12) and Bede (Exposition of the Apocalypse, on Rev 8:1) it represents rest for those remaining after the death of Antichrist.

${ }^{141}$ Cf. Isa 11:2; Pseudo-Jerome, Handbook on the Apocalypse of the Apostle John, on Rev 8:2.

${ }^{142}$ Cf. the Reference Bible's comments on Rev 5:1.

${ }^{143}$ Cf. Tyconius, Exposition of the Apocalypse, on Rev 8:3, CCSL 107A:152; PseudoJerome, Handbook on the Apocalypse of the Apostle John, on Rev 8:3. 
${ }^{144}$ Cf. Bede, Exposition of the Apocalypse, on Rev 8:3, CCSL 121A:335, trans. Weinrich, 137.

${ }_{145}$ Cf. Pseudo-Jerome, Handbook on the Apocalypse of the Apostle John, on Rev 8:3.

${ }^{146}$ Cf. Pseudo-Jerome, Handbook on the Apocalypse of the Apostle John, on Rev 8:3.

${ }^{147}$ Cf. Bede, Exposition of the Apocalypse, on Rev 8:7, trans. Weinrich, 138.

${ }^{148}$ Cf. Tyconius, Exposition of the Apocalypse, on Rev 8:7, CCSL 107A:154.

${ }^{149}$ Cf. Pseudo-Jerome, Handbook on the Apocalypse of the Apostle John, on Rev 8:8.

${ }^{150}$ Cf. Bede, Exposition of the Apocalypse, on Rev 8:10, trans. Weinrich, 139.

${ }^{151}$ Lat. pro persona maiorum perhaps "our ancestors" Cf. Tyconius, Exposition of the Apocalypse, on Rev 8:10, CCSL 107A:155.

${ }^{152}$ The idea is that as stars display varying brightness, so the saints have diversity with respect to merits. Cf. Matt 13:23, 1 Cor 15:41.

${ }^{153}$ Cf. Rom 1:26.

154 Tyconius, Exposition of the Apocalypse, on Rev 8:12, CCSL 107A:156.

155 On this passage, Primasius of Hadrumetum (CCSL 92:144) also quotes this verse from Philippians.

${ }^{156}$ Tyconius, Exposition of Revelation, on Rev 9:1, CCSL 107A:156.

${ }^{157}$ Cf. Pseudo-Jerome, Handbook on the Apocalypse of the Apostle John, on Rev 9:1.

${ }^{158}$ Cf. Caesarius of Arles, Exposition of the Apocalypse of John, homily 7, trans. Weinrich, 80 .

${ }^{159}$ Cf. Cf. Pseudo-Jerome, Handbook on the Apocalypse of the Apostle John, on Rev 9:3.

${ }^{160}$ Lat. elevatione perhaps "distraction."

161 Tyconius, Exposition of the Apocalypse, on Rev 9:5, CCSL 107A:158. Tyconius interprets the torments as the persecution of the Donatists in North Africa by Constantine from the years 316-21, which he foresees as a shadow of the last persecution. See the comments of The Reference Bible on Rev 9:10-12, which again quote directly from Tyconius.

${ }^{162}$ Cf. Tyconius, Exposition of the Apocalypse, on Rev 9:7, CCSL 107A:158, who says "like the last persecutors."

${ }^{163}$ Cf. Rev 4:4; Tyconius, Exposition of the Apocalypse, on Rev 9:7, CCSL 107A:158.

${ }_{164}$ Cf. 2 Tim 3:6; Primasius of Hadrumetum, Commentary on the Apocalypse, on Rev 9:7, CCSL 92:150.

${ }^{165}$ Lat. humanitatem emitentur or "feign kindness."

${ }^{166}$ Tyconius, Exposition of the Apocalypse, on Rev 9:10, CCSL 107A:159.

${ }^{167}$ Cf. Rev 10:7, 11:15ff.

${ }^{168}$ Gryson indicated a lacuna for which I have supplied "bring about."

${ }^{169}$ Cf. Bede, Exposition of the Apocalypse, on Rev 9:14, trans. Weinrich, 142.

${ }^{170}$ Cf. Caesarius of Arles, Exposition of the Apocalypse of John, homily 7, trans. Weinrich,

79; Primasius of Hadrumetum, Commentary on the Apocalypse, on Rev 9:15, CCSL 92:153.

${ }^{171}$ Cf. Primasius of Hadrumetum, Commentary on the Apocalypse, on Rev 9:17, CCSL 92:156.

${ }^{172}$ Cf. Primasius of Hadrumetum, Commentary on the Apocalypse, on Rev 10:1, CCSL 92:159, who says "Christ the Lord." Victorinus, Tyconius, Caesarius, and Bede similarly all say that the angel represents "the Lord."

${ }^{173}$ Cf. Pseudo-Jerome, Handbook on the Apocalypse of the Apostle John, on Rev 10:1.

${ }^{174}$ Cf. Tyconius, Exposition of the Apocalypse, on Rev 10:1, CCSL 107A:163.

${ }^{175}$ Cf. Tyconius, Exposition of the Apocalypse, on Rev 10:1, CCSL 107A:163. 
${ }^{176}$ Cf. Tyconius, Exposition of the Apocalypse, on Rev 10:2, CCSL 107A:164; Pseudo-Jerome, Handbook on the Apocalypse of the Apostle John, on Rev 10:2.

177 Cf. Primasius of Hadrumetum, Commentary on the Apocalypse, on Rev 10:3, CCSL 92:161.

${ }^{178}$ Cf. Isa 11:2; Victorinus of Pettau, Commentaries on the Apocalypse, on Rev 10:3, CSEL 49:90-91; Pseudo-Jerome, Handbook on the Apocalypse of the Apostle John, on Rev 10:3; Bede, Exposition of the Apocalypse, on Rev 10:3, trans. Weinrich, 144.

179 Tyconius, Exposition of the Apocalypse, on Rev 10:4, CCSL 107A:164.

${ }^{180}$ Tyconius, Exposition of the Apocalypse, on Rev 10:4, CCSL 107A:164.

${ }^{181}$ Cf. 1 Cor 15:52; Rev 11:15ff; Tyconius, Exposition of the Apocalypse, on Rev 10:57, CCSL 107A:165.

${ }^{182}$ Cf. Tyconius, Exposition of the Apocalypse, on Rev 10:10-11, CCSL 107A:166.

${ }_{183}$ Tyconius, Exposition of the Apocalypse, on Rev 10:9, CCSL 107A:165.

${ }^{184}$ Cf. Tyconius, Exposition of the Apocalypse, on Rev 10:9, CCSL 107A:165.

${ }^{185}$ Cf. Pseudo-Jerome, Handbook on the Apocalypse of the Apostle John, on Rev 11:2.

${ }^{186}$ Cf. Tyconius, Exposition of the Apocalypse, on Rev 11:2, CCSL 107A:166.

${ }^{187}$ Lat. hereses (heresies), but from the quotation of Matt 7:6 it seems the author is using the word to refer to the people of heresy rather than the teaching.

${ }^{188}$ Cf. Tyconius, Exposition of the Apocalypse, on Rev 11:2, CCSL 107A:166.

${ }^{189}$ Cf. Pseudo-Jerome, Handbook on the Apocalypse of the Apostle John, on Rev 11:2.

${ }^{190}$ Cf. Pseudo-Jerome, Handbook on the Apocalypse of the Apostle John, on Rev 11:3. The identification of the two witnesses as Enoch and Elijah was very common in early Christianity. Cf. Hippolytus, On Daniel, on Dan 4:35, and Tertullian, On the Soul, 50. See also Mackay, "Early Christian Millenarianist Interpretation of the Two Witnesses," who in addition cites as witnesses of this opinion the Gospel of Nicodemus, Augustine, Quodvultdeus, Cassiodorus, and Gregory the Great.

${ }^{191}$ Tyconius, Exposition of the Apocalypse, on Rev 11:3, CCSL 107A:167.

${ }^{192}$ Meaning, the historical sense.

${ }^{193}$ Jerome, On Hebrew Names, Acts, PL 23:845; Jude, PL 23:852; Hebrews, PL 23:855.

${ }^{194}$ Cf. Tyconius, Exposition of the Apocalypse, on Rev 11:9, CCSL 107A:170.

${ }^{195}$ Concerning the practice of building monasteries over the burial places of holy people in the early middle ages, the burial place of the martyred bishop Emmeran at Regensburg "became the site of a powerful monastery from the the mid-8th century"; Matthew, Atlas of Medieval Europe, 47.

196 That is, places of entombment or graveyards. Lat. esse in locis in quibus sepulti sunt in mundo, literally "to be in places in which they are buried in the world."

${ }^{197}$ Tyconius, Exposition of the Apocalypse, on Rev 11:12, CCSL 107A:171.

${ }^{198}$ Cf. Tyconius, Exposition of the Apocalypse, on Rev 11:13, CCSL 107A:172; Pseudo-Jerome, Handbook on the Apocalypse of the Apostle John, on Rev 12:1.

${ }^{199}$ Lat. ecclesia que minor est, meaning the lay persons and persons of lower ecclesiastical rank who are under the authority of those in higher ranks, such as bishops and archbishops. It is an allusion to Gen 1:16, where the moon is called the "lesser light."

${ }^{200}$ Tyconius, Exposition of the Apocalypse, on Rev 12:1, CCSL 107A:175.

${ }^{201}$ Cf. Rev 12:9.

${ }^{202}$ For the interpretation of the heads as seven kings and the horns as kingdoms, cf. Pseudo-Jerome, Handbook on the Apocalypse of the Apostle John, on Rev 12:1; Primasius of 
Hadrumetum, Commentary on the Apocalypse, on Rev 12:3, CCSL 92:180, who is dependent upon Tyconius, Exposition of the Apocalypse, on Rev 12:3, CCSL 107A:175.

${ }^{203}$ Cf. Tyconius, Exposition of the Apocalypse, on Rev 12:3, CCSL 107A:175, who interprets the tail as "wicked prophets."

${ }^{204}$ Victorinus of Pettau (Commentaries on the Apocalypse, on Rev 12:4, CSEL 49:116-

17) believes that this referred to a third part of the angels, but writes that "Many understand this to mean that he was able to seduce a third of the believers"; trans. Weinrich, 17.

${ }^{205}$ Cf. Matt 2:16. Cf. Tyconius, Exposition of the Apocalypse, on Rev 12:3, CCSL 107A:175.

${ }^{206}$ Cf. Victorinus of Pettau, Commentaries on the Apocalypse, on Rev 12:5, CSEL 49:108-09; Primasius of Hadrumetum, Commentary on the Apocalypse, on Rev 12:5, CCSL 92:182.

${ }^{207}$ Cf. Matt 2:14.

${ }^{208}$ Jerome, Commentary on Daniel, on Rev 11:41, trans. Archer, 140.

${ }^{209}$ Jerome, On Hebrew Names, Num, Dan. Iud, Apoc, PL 23:840, 880, 896, 902.

${ }^{210}$ For the interpretation of Michael as Christ, and his holy angels as holy people, cf. Tyconius, Exposition of the Apocalypse, on Rev 12:7-8, CCSL 107A:178.

${ }^{211}$ Cf. Pseudo-Jerome, Handbook on the Apocalypse of the Apostle John, on Rev 12:3.

${ }^{212}$ Cf. Tyconius, Exposition of the Apocalypse, on Rev 12:9, CCSL 107A:179.

${ }^{213}$ Tyconius, Exposition of the Apocalypse, on Rev 12:14, CCSL 107A:180.

${ }^{214}$ Cf. Tyconius, Exposition of the Apocalypse, on Rev 12:14, CCSL 107A:180.

${ }^{215}$ Cf. Tyconius, Exposition of the Apocalypse, on Rev 12:15-16. CCSL 107A:18-81.

${ }^{216}$ Cf. Tyconius, Exposition of the Apocalypse, on Rev 12:15-16, who interprets earth as "the saints" (CCSL 107A:180); Primasius of Hadrumetum, Commentary on the Apocalypse, on Rev 12:16 (CCSL 92:189), who says that it is possible to interpret earth as "the church," but prefers to interpret it as a reference to "the human nature in Christ"; Bede, Exposition of the Apocalypse, on Rev 12:16 (trans. Weinrich, 152), who interprets earth as "the holy flesh of the Lord."

${ }^{217}$ The edition has the Latin word in here.

${ }^{218}$ Tyconius, Exposition of the Apocalypse, on Rev 13:1, CCSL 107A:181.

219 Throughout this whole chapter I have translated pronouns and personal adjectives for the beast as "his" and "him" rather than "it" because of the personification and deeds of the beast.

${ }^{220}$ This is probably a rejection of the ancient Celtic belief in transmigration of souls. See also the comment below on Rev 13:12.

${ }^{221}$ Tyconius, Exposition of the Apocalypse, on Rev 13:1, CCSL 107A:182. This rejects the belief in apotheosis common among ancient Romans.

${ }^{222}$ Lat. ordo principum. The comment explains the meaning of "heads."

${ }^{223}$ Tyconius, Exposition of the Apocalypse, on Rev 13:5, CCSL 107A:183.

${ }^{224}$ Cf. Tyconius, Exposition of the Apocalypse, on Rev 13:5, CCSL 107A:183.

${ }^{225}$ Cf. Tyconius, Exposition of the Apocalypse, on Rev 13:7, CCSL 107A:183.

${ }^{226}$ Tyconius, Exposition of the Apocalypse, on Rev 13:8, CCSL 107A:183.

${ }^{227}$ Cf. Gen 4:8.

${ }^{228}$ Cf. Tyconius, Exposition of the Apocalypse, on Rev 13:11, CCSL 107A:184.

${ }^{229}$ Tyconius, Exposition of the Apocalypse, on Rev 13:11, CCSL 107A:184.

${ }^{230}$ Tyconius, Exposition of the Apocalypse, on Rev 13:11, CCSL 107A:184. 
${ }^{231}$ Cf. Mark 7:21-23; Luke 6:45.

${ }^{232}$ That the beast is the Christ.

${ }^{233}$ That is, agreeing with or consenting to the two beasts.

${ }^{234}$ Cf. Tyconius, Exposition of the Apocalypse, on Rev 13:15, CCSL 107A:186-87.

${ }^{235}$ Lat. nota or "stamp," "impression," "tattoo," or "branding."

${ }^{236}$ The variant, which has the number of the beast as six hundred and sixteen, is in the Apocalypse commentaries of Tyconius and Caesarius of Arles. It was attested to in Papyrus Oxyr. 4499 (also known as P115), Codex Ephraemi rescriptus, and Irenaeus of Lyons (Against Heresies 5:30). See Gumerlock, "The Number of Nero Antichrist," 143, 146; Williams, "P115 and the Number of the Beast"; and Gumerlock, "Nero Antichrist."

${ }^{237}$ Here the manuscripts contain many variants, marginalia, and erasures.

${ }^{238}$ Lat. episimon.

${ }^{239}$ Lat. una.

${ }^{240}$ Lat. in istoria libri.

${ }^{241}$ Anonymous, Preface to the Gospel according to Mark, which the author of the Reference Bible attributed to Jerome.

${ }^{242}$ A transposition of the Roman letters for six hundred and sixty-six, DCLXVI, is DICLVX forming the Latin words dic (say) and lux (light); hence, the quotation of the verse from 2 Corinthians. It was believed that the beast, in imitation of Christ, will say that he is the light or will have others call him "Light." Cf. Victorinus of Pettau, Commentaries on the Apocalypse, on Rev 13:18, CSEL 49:124-25.

${ }^{243}$ For the interpretation "teitan," cf. Irenaeus, Against Heresies, 5.30, 3 (ANF 1:559); Hippolytus, On Christ and the Antichrist, 50 (ANF 5:215); Victorinus of Pettau, Commentaries on the Apocalypse, on Rev 13:18 (CSEL 49:124-25); Excerpta de monogramma (CCSL 107:151).

${ }^{244}$ Cf. Pseudo-Jerome, Handbook on the Apocalypse of the Apostle John, on Rev 13:17.

${ }^{245}$ In Gryson's edition, above the letters of this name are written the Latin numerals, I L CCC V XL LXX CC, or one, fifty, three hundred, five, forty, seventy, and two hundred, respectively.

${ }^{246}$ Anti (contrary) + timos (honor). Beatus of Liebana (ca. 786) explains antemos as abstemius meaning "abstaining from wine"; CCSL 107C:715. Possibly it may have originally been a reference to Anthemius, appointed Roman consul in 455 and western emperor in 467, who was disliked by many in Italy and whom some Christians may have regarded as the beast.

${ }^{247}$ The author seems to be making a correlation between the word anathema, a judiciary sentence in which one is accursed by God, and antemos.

248 Anonymous, Excerpta de monogramma, CCSL 107:152-53; Primasius of Hadrumetum, Commentary on the Apocalypse, on Rev 13:18, CCSL 92:203-04.

${ }^{249}$ In Gryson's edition, above the letters of this name are written the Latin numerals, I C L LXX CCCC XL V, or one, one hundred, fifty, seventy, four hundred, forty, and five, respectively.

${ }^{250}$ This interpretation appears in pseudo-Hippolytus, On the End of the World, 28, ANF 5:249.

${ }^{251}$ Anonymous, Excerpta de monogramma, CCSL 107:153-54; Primasius of Hadrumetum, Commentary on the Apocalypse, on Rev 13:18, CCSL 92:204-05.

${ }^{252}$ In Gryson's edition, above the letters of this name are written the Latin numerals, 
DC C X CC CCC V X, or six hundred, one hundred, ten, two hundred, three hundred, five, and ten, respectively.

253 The excerpt from Primasius, which calls the beast adversitas, is dependent upon Tyconius, Exposition of the Apocalypse, on Rev 13:18 (CCSL 107A:187) where Tyconius has: et cui se similem facit adversitas compared with the Latin here and in Primasius: in cuius se spetie fraudulenter opponit adversitas. The term adversitas for the beast probably had its basis in 1 Tim 5:14 or 1 Pet 5:8, where the devil is called adversarius or "adversary." Regarding resemblance to Christ, the author is suggesting that the three and a half years of Antichrist's persecution resembles the three and a half years of Christ's ministry.

${ }^{254}$ In Gryson's edition, above the letters of this name are written the Latin numerals, DC C X CC CCC V X, or six hundred, one hundred, ten, two hundred, three hundred, five, and ten, respectively.

255 Anonymous, Excerpta de monogramma, CCSL 107:154; Primasius of Hadrumetum, Commentary on the Apocalypse, on Rev 13:18, CCSL 92:205-06.

${ }^{256}$ In Gryson's edition, above the letters of this name are written the Latin numerals, I IIII I XL, or one, four, one, and forty, respectively.

${ }^{257}$ In Gryson's edition, above the letters of this name are written the Latin numerals, XX LXX CCCC I IIII C I IIII X L CCC I CC V LX, or twenty, seventy, four hundred, one, four, one hundred, one, four, ten, fifty, three hundred, one, two hundred, five, and sixty, respectively.

258 Anonymous, Excerpta de monogramma, CCSL 107:155-56; Primasius of Hadrumetum, Commentary on the Apocalypse, on Rev 13:18, CCSL 92:206-07.

259 The Creed.

${ }^{260}$ Primasius of Hadrumetum, Commentary on the Apocalypse, on Rev 13:17, CCSL 92:203. Cf. Bede, Exposition of the Apocalypse, on Rev 13:17, trans. Weinrich, 156.

${ }^{261}$ Cf. Gen 4:15.

${ }^{262}$ Gryson was unable to locate this in the works of Jerome.

${ }^{263}$ Cf. Tyconius, Exposition of the Apocalypse, on Rev 13:18, CCSL 107A:187.

${ }^{264}$ Primasius of Hadrumetum, Commentary on the Apocalypse, on Rev 13:18, CCSL

92:207-08.

${ }^{265}$ I was unable to locate this passage.

${ }^{266}$ Regarding the citations from Daniel and Acts, cf. Primasius of Hadrumetum, Commentary on the Apocalypse, on Rev 13:18, CCSL 92:208.

${ }^{267}$ Or “Chresimon.” Isidore of Seville, Etymologies, 1.21, 1.22, PL 82:98.

${ }^{268}$ The belief that the place where Christ will come again for judgment is Mount Zion or more specifically the Mount of Olives overlooking the Valley of Jehoshaphat is based upon Joel 3:12, Zech 14:4, and Acts 1:11.

${ }^{269}$ Cf. 1 Pet 1:18-19, and Rev 5:9.

${ }^{270}$ Lat. in exemplis. That is, they follow the pattern of Christ's life and model him in their deeds.

${ }^{271}$ Tyconius, Exposition of the Apocalypse, on Rev 14:6, CCSL 107A:189; Cf. PseudoJerome, Handbook on the Apocalypse of the Apostle John, on Rev 14:6.

${ }^{272}$ Cf. Tyconius, Exposition of the Apocalypse, on Rev 14:5, CCSL 107A:188.

${ }^{273}$ Jerome, On Hebrew Names, Gen, Psalms, Joshua, 1 Pet, Apoc, PL 23:776, 802, 828,

851, 858; Caesarius of Arles, Exposition of the Apocalypse, homily 16, trans. Weinrich, 97.

${ }^{274}$ Lat. lacum literally "lake," but here meaning "wine vat." 
${ }^{275}$ One stadion was approximately six hundred feet in length.

${ }^{276}$ Lat. vindica or "judgment."

277 Cf. Tyconius, Exposition of the Apocalypse, who on Rev 14:20 has usque ad rectores populorum (up to the rulers of the peoples); CCSL 107A:193.

${ }^{278}$ Cf. Tyconius, Exposition of the Apocalypse, on Rev 14:20, CCSL 107A:194.

${ }^{279}$ Cf. Pseudo-Jerome, Handbook on the Apocalypse of the Apostle John, on Rev 15:2.

${ }^{280}$ Cf. Tyconius, Exposition of the Apocalypse, on Rev 15:2, CCSL 107A:194.

${ }^{281}$ Tyconius, Exposition of the Apocalypse, on Rev 15:2, CCSL 107A:194.

${ }^{282}$ Tyconius, Exposition of the Apocalypse, on Rev 15:3, CCSL 107A:194.

${ }^{283}$ Cf. Tyconius, Exposition of the Apocalypse, on Rev 15:5-6, CCSL 107A:195.

${ }^{284}$ Cf. Rom 13:14; Gal 3:27; Cf. Pseudo-Jerome, Handbook on the Apocalypse of the Apostle John, on Rev 15:6.

${ }^{285}$ Meaning, when Christ speaks in any of the Gospels, which he saw represented by the four living creatures. See his comments on Rev 4:6: "Four living creatures, that is, the four Gospels."

${ }^{286}$ Cf. Pseudo-Jerome, Handbook on the Apocalypse of the Apostle John, on Rev 15:8.

${ }^{287}$ Cf. Caesarius of Arles, Exposition of the Apocalypse, homily 12, trans. Weinrich, 91.

${ }^{288}$ Cf. Primasius of Hadrumetum, Commentary on the Apocalypse, on Rev 16:3, CCSL 92:227.

${ }^{289}$ Tyconius, Exposition of the Apocalypse, on Rev 16:9, CCSL 107A:198.

${ }^{290}$ Tyconius, Exposition of the Apocalypse, on Rev 16:11, CCSL 107A:198.

${ }^{291}$ Tyconius, Exposition of the Apocalypse, on Rev 16:12, CCSL 107A:198.

${ }^{292}$ Cf. Tyconius, Exposition of the Apocalypse, on Rev 16:12, CCSL 107A:198.

${ }^{293}$ Tyconius, Exposition of the Apocalypse, on Rev 16:13, CCSL 107A:199.

${ }^{294}$ Cf. 2 Tim 2:16.

295 Tyconius, Exposition of the Apocalypse, on Rev 16:14, CCSL 107A:199.

${ }^{296}$ Tyconius, Exposition of the Apocalypse, on Rev 16:14, CCSL 107A:199.

${ }^{297}$ Jerome, On Hebrew Names. Apoc, PL 23:858.

${ }^{298}$ Lat. fictum or "deceitful" or "feigned."

${ }^{299}$ Tyconius, Exposition of the Apocalypse, on Rev 16:17, CCSL 107A:201.

${ }^{300}$ For a similar comment by this author, see his comment on Rev 8:7.

301 Cf. Gen 11:9; Primasius of Hadrumetum, Commentary on the Apocalypse, on Rev 16:19, CCSL 92:235.

302 Cf. Tyconius, Exposition of the Apocalypse, on Rev 16:19-20, CCSL 107A:202;

Pseudo-Jerome, Handbook on the Apocalypse of the Apostle John, on Rev 16:20.

${ }^{303}$ This should read "five," as it reads later when he lists the five emperors who have fallen.

${ }^{304}$ Cf. Tyconius, Exposition of the Apocalypse, on Rev 17:3, CCSL 107A:203.

${ }^{305}$ Cf. Tyconius, Exposition of the Apocalypse, on Rev 17:3, CCSL 107A:204.

${ }^{306}$ Tyconius, Exposition of the Apocalypse, on Rev 17:4, CCSL 107A:204.

${ }^{307}$ Cf. Matt 5:17.

${ }^{308}$ Cf. Tyconius, Exposition of the Apocalypse, on Rev 17:7-8, CCSL 107A:205.

${ }^{309}$ Cf. Luke 2:1-7.

${ }^{310}$ Cf. Acts 11:28.

311 Tyconius, Exposition of the Apocalypse, on Rev 17:10, CCSL 107A:206.

${ }^{312}$ Lat. istoriam, or "according to a literal reading."

${ }^{313}$ Tyconius, Exposition of the Apocalypse, on Rev 17:12, CCSL 107A:207; Isa 29:7-8. 
${ }^{314}$ Lat. moribus or "character."

315 Cf. Primasius of Hadrumetum, Commentary on the Apocalypse, on Rev 18:2, CCSL 92:251; Pseudo-Jerome, Handbook on the Apocalypse of the Apostle John, on Rev 18:2; Bede, Exposition of the Apocalypse, on Rev 18:1, trans. Weinrich, 171.

${ }^{316}$ Angels will be the instruments executing this judgment.

${ }^{317}$ Lat. pigmenta, or "crafts," "ornaments," or "decorations."

318 Cf. Tyconius, Exposition of the Apocalypse, on Rev 18:17-18, 18:21-23, CCSL 107A:212-13.

${ }^{319}$ Here Gregory has Redemptoris or "of the Redeemer" for Christi.

${ }^{320}$ Lat. adsumptam. Since Christ assumed human nature, all of human nature has now risen above the angels.

${ }^{321}$ Gregory the Great, Homilies on the Gospels, 8.2, PL 76:1105.

${ }^{322}$ Lat. lingua, literally "tongue."

${ }^{323}$ Cf. Pseudo-Jerome, Handbook on the Apocalypse of the Apostle John, on Rev 19:11.

${ }^{324}$ Cf. Tyconius, Exposition of the Apocalypse, on Rev 19:12, CCSL 107A:215.

325 "his flesh" is an interpretation of the word "robe" in the verse. Cf. Gregory the Great, Homilies on Ezekiel, 2.1, CCSL 142:215.

${ }^{326}$ Cf. Tyconius, Exposition of the Apocalypse, on Rev 19:14, CCSL 107A:215.

${ }^{327}$ Cf. Eph 6:17, and Heb 4:12.

${ }^{328}$ Tyconius, Exposition of the Apocalypse, on Rev 19:17, CCSL 107A:216.

329 Cf. Ps 58:10; Tyconius, Exposition of the Apocalypse, on Rev 19:21, CCSL 107A:217-18; Primasius of Hadrumetum, Commentary on the Apocalypse, on Rev 19:21, CCSL 92:270; Bede, Exposition of the Apocalypse, on Rev 19:20-21, trans. Weinrich, 177.

${ }^{330}$ Cf. Tyconius, Exposition of the Apocalypse, on Rev 19:19, CCSL 107A:216.

${ }^{331}$ Tyconius, Exposition of the Apocalypse, on Rev 20:1, CCSL 107A:218.

${ }^{332}$ Cf. Tyconius, Exposition of the Apocalypse, on 20:1, CCSL 107A:218.

${ }^{333}$ Cf. Jerome, Commentary on the Apocalypse, on Rev 20:3, CSEL 49:143; Augustine, On the City of God, 20.8, trans. Dods, 722; Primasius of Hadrumetum, Commentary on the Apocalypse, on Rev 20:3, CCSL 92:275.

${ }^{334}$ Tyconius, Exposition of the Apocalypse, on Rev 20:3, CCSL 107A:219.

${ }^{335}$ Cf. Augustine, On the City of God, 20.9, trans. Dods, 726.

${ }^{336}$ Cf. Tyconius, Exposition of the Apocalypse, on Rev 20:4, CCSL 107A:222.

${ }^{337}$ Cf. Jerome, On Hebrew Names, Apoc, PL 23:858; Primasius of Hadrumetum, Commentary on the Apocalypse, on Rev 20:7, CCSL 92:279; Bede, Exposition of the Apocalypse, on Rev 20:7, trans. Weinrich, 180.

${ }^{338}$ Cf. 1 Cor 7:31; Augustine, On the City of God, 20.14, trans. Dods, 772; Primasius of Hadrumetum, Commentary on the Apocalypse, on Rev 20:11, CCSL 92:282; Bede, Exposition of the Apocalypse, on Rev 20:11, trans. Weinrich, 180.

${ }_{339}$ Tyconius, Exposition of the Apocalypse, on Rev 20:11-12, CCSL 107A:222.

340 Cf. Primasius of Hadrumetum, Commentary on the Apocalypse, on Rev 20:12, CCSL 92:282; Bede, Exposition of the Apocalypse, on Rev 20:15, trans. Weinrich, 181.

341 The edition has angulos or "corners" not angelos or "angels." But the comment on this verse below reads angeli.

${ }^{342}$ In Gryson's edition, the Scripture quotation goes from Rev 21:10-22:4, followed by commentary. But this translation cites only Rev 21:10-27 here, followed by commentary, and then in the next chapter cites Rev 22:1-4 with commentary. 
${ }^{343}$ Cf. Tyconius, Exposition of the Apocalypse, on Rev 21:10, CCSL 107A:223.

${ }^{344}$ Cf. Heb 12:22-23.

${ }^{345}$ Cf. Matt 17:1-2; Mark 9:2-3.

${ }^{346}$ Lat. praepositi or "superintendents" or "leaders." I have translated it here and later in the text as "bishops." Cf. Tyconius, Exposition of the Apocalypse, on Rev 21:12, CCSL 107A:224.

${ }^{347}$ Here the commentator goes slightly out of order by loosely referring to the text of 21:14. The text of 21:13 will be commented on next, followed by that of 21:15.

${ }^{348}$ Cf. Tyconius, Exposition of the Apocalypse, on Rev 21:13, CCSL 107A:224.

349 The Latin name for the east (oriens) comes from the path of the sun in the sky, and literally means "the rising." Hence the connection between the beginning of the sun's path and the beginning of a person's life.

350 There may be a loose explanation for this interpretation in the likeness between the Latin words for north (aquilo) and swarthy (aquilus), and between a swarthiness of complexion from the heat of the sun and the trying of faith and the purification of gold, an analogy found in 1 Pet 1:7.

351 There is a possible relation between the Latin for south (auster), stern (austerus), and the quality of faith here described ( firma). Incidentally, this comment does not follow the east, north, west, south order of the text originally quoted.

${ }^{352}$ Here the Latin for west (occidens) again follows the path of the sun and literally means "dying." Hence, the comment on old age and the end of a person's life.

${ }^{353}$ Cf. Primasius of Hadrumetum, Commentary on the Apocalypse, on Rev 21:15-16 (CCSL 92:292), who wrote that "it should be understood as Christ, who is the wisdom of God."

${ }^{354}$ Cf. Pseudo-Jerome, Handbook on the Apocalypse of the Apostle John, on Rev 21:16.

355 No passage is quoted, but he most likely has in mind Eph 3:18-19, where Paul prays that the Ephesians might know the breadth of the love of Christ.

${ }^{356}$ Cf. Rev 7:4, 14:1, 14:3.

${ }^{357}$ In this comment homines (men or humans) are in contrast with angels not women. ${ }^{358}$ Cf. Rev 3:18.

${ }^{359}$ Tyconius, Exposition of the Apocalypse, on Rev 21:21, CCSL 107A:225.

${ }^{360}$ Tyconius, Exposition of the Apocalypse, on Rev 21:21, CCSL 107A:225.

${ }^{361}$ Tyconius, Exposition of the Apocalypse, on Rev 21:22-23, CCSL 107A:225.

${ }^{362}$ Tyconius, Exposition of the Apocalypse, on Rev 21:23, CCSL 107A:225; Cf. Mal 4:2.

${ }^{363}$ Tyconius, Exposition of the Apocalypse, on Rev 21:23, CCSL 107A:225.

${ }^{364}$ Cf. 1 Thess 5:5, 5:7.

${ }^{365}$ Tyconius, Exposition of the Apocalypse, on Rev 22:1, CCSL 107A:226.

${ }^{366} \mathrm{Cf}$. Apringius of Beja, Explanation of the Apocalypse, on Rev 22:1, trans. Weinrich, 60.

${ }^{367}$ Tyconius, Exposition of the Apocalypse, on Rev 22:2, CCSL 107A:226.

368 Tyconius, Exposition of the Apocalypse, on Rev 22:2, CCSL 107A:226.

${ }^{369}$ Lat. facta est.

${ }^{370}$ Tyconius, Exposition of the Apocalypse, on Rev 22:2, CCSL 107A:226.

${ }^{371} \mathrm{Cf}$. Apringius of Beja, Explanation of the Apocalypse, on Rev 22:3, trans. Weinrich, 60.

${ }^{372}$ Cf. Tyconius, Exposition of the Apocalypse, on Rev 22:10-14, CCSL 107A:227.

${ }^{373}$ Lat. sentiunt or "feel" or "think," meaning, those who interpret the book. Tyconius, Exposition of the Apocalypse, on Rev 22:18-20, CCSL 107A:228. 
${ }^{374}$ Lat. pro labore impletionis. I believe I have captured the meaning related to scribes who work hastily to get their work finished and are careless about completing such duty with precision. But since the phrase can be translated "for the labor of fulfillment," the commentator could be referring to those, who with a doomsday mindset, add to or take away from the Revelation in an effort to show that its prophecies are being fulfilled. 


\title{
Early Latin Commentaries Bibliography
}

\author{
Primary Sources
}

Alcuin. Commentary on the Apocalypse. PL 100.

Ambrose Autpert. Expositionis in Apocalypsin libri I-V [Books 1-5 of the Exposition of the Apocalypse]. CCCM 27.

Andrew of Caesarea. Commentary on the Apocalypse. FC 123. English: Greek Commentaries on Revelation. Translated by William C. Weinrich, 109-208. Downers Grove, IL: InterVarsity, 2011.

Apocalypse of Peter. Edited by A. Mingana in Woodbrooke Studies: Christian

Documents in Syriac, Arabic, and Garshuni, 3:93-449. Cambridge: Heffer, 1931.

Apocalypse of pseudo-Methodius. Edited by W.J. Aerts and G.A.A. Kortekaas as Die Apokalypse des pseudo-Methodius die ältesten griechischen und lateinischen Übersetzungen. Louvain: Peeters, 1998.

Apocrypha Hiberniae I, 1: Evangelia Infantiae. Edited by Martin McNamara and others. Corpus Christianorum Series Apocryphorum 13. Turnhout: Brepols, 2001.

Apringius of Beja. Tractatus in Apocalypsin [Explanation of the Apocalypse]. CCSL 107:33-97. English: Latin Commentaries on Revelation. Translated by William C. Weinrich, 23-62. Downers Grove, IL: InterVarsity, 2011.

Augustine. Expositions of the Book of Psalms. NPNF, 1st ser., 8.

- On the City of God. Translated by Marcus Dods. New York: Random House, 1950.

. On the Gospel of John. NPNF, 1 st ser., 7.

Beatus of Liebana. Commentary on the Apocalypse. CCSL 107B-C. Edited by E. Romero-Pose as Sancti Beati a Liebana Commentarius in Apocalypsin. 2 vols. Rome: Typis Officinae Polygraphicae, 1985. Edited by Henry A. Sanders as Beati in Apocalypsin libri duodecim. Rome: American Academy, 1930.

Bede. Expositio Apocalypseos [Exposition of the Apocalypse]. CCSL 121A. 
English: Latin Commentaries on Revelation. Translated by William Weinrich, 110-95. Bede: Commentary on Revelation. Translated by Faith Wallis. Texts for Historians 58. Liverpool: Liverpool University Press, 2013.

Berengaudus. Expositio super septem visions libri Apocalypsis [Exposition of the Seven Visions of the Book of the Apocalypse]. PL 17:763-970.

Caesarius of Arles. Explanatio in Apocalypsin [Exposition of the Apocalypse].

Edited by German Morin as Sancti Caesarii Arelatensis opera varia, 2:209-77. Maretioli [Bruges]: Desclée, 1942. English: Latin Commentaries on Revelation. Translated by William Weinrich, 63-109.

Cambridge Gloss on the Apocalypse. CCSL 108G.

Catechesis Celtica. Edited by André Wilmart in Analecta Reginensia, 29-112.

Vatican City: Biblioteca Apostolica Vaticana, 1933.

Commentaria minora in Apocalypsin Iohannis. CCSL 107.

Commentarius in Epistolas Catholicas Scotti Anonymi [Commentary on the

Catholic Epistles of an Anonymous Irishman]. CCSL 108B.

Cyprian of Carthage. Ad Fortunatum [To Fortunatus]. ANF 5. . Ad Quirinum [To Quirinus]. ANF 5.

Dionysius of Alexandria. On the Promises. Fragments. ANF 6:81-84.

Ephraim the Syrian. Antichrist, the Second Coming of the Lord, The End of the World. Willits, CA: Eastern Orthodox Books, 2003.

Eusebius of Caesarea. Ecclesiastical History. Translated by Christian Frederick Cruse. Grand Rapids, MI: Baker, 1987.

Excerpta de monogramma. CCSL 107:131-57.

Filastrius of Brixia. Diversarum hereseon liber [Book of Diverse Heresies].

CCSL 60.

Fragment of an Apocalypse and Death of John. Edited by Máire Herbert and Martin McNamara in Irish Biblical Apocrypha: Selected Texts in Translation, 95. New York: T \& T Clark, 1989.

Gregory the Great. Dialogues. SC 251, 260, and 265. English: FC 39.

- Homiliae in Evangelia [Homilies on the Gospels]. CCSL 141; PL 76. English: Gregory the Great. Forty Gospel Homilies. Translated by David Hurst. Cistercian Studies Series 123. Kalamazoo: Cistercian, 1990. - Homilies on Ezekiel. CCSL 142; PL 76. English: The Homilies of Saint Gregory the Great on the Book of the Prophet Ezekiel. Translated by Theodosia Grey. Etna, CA: Center for Traditionalist Orthodox Studies, 1990.

- Letters. CCSL 140 and 140A. English: The Letters of Gregory the Great. Translated by John R. C. Martyn. 3 vols. Medieval Sources in 
Translation 40. Toronto: Pontifical Institute of Mediaeval Studies, 2004.

- Morals on the Book of Job. Library of the Fathers of the Holy Catholic Church 18, 21, 23, 31. 4 vols. Oxford: John Henry Parker, 1844-50.

- On the Song of Songs. SC 314. English: Gregory the Great on the Song of Songs. Translated by Mark DelCogliano, 109-44. Cistercian Studies Series 244. Collegeville, MN: Liturgical Press, 2012.

- Pastoral Rule. SC 381 \& 382. English: ACW 11. St. Gregory the Great. The Book of Pastoral Rule. Translated by E. Demacopoulos. Popular Patristics Series 34. Crestwood, NY: St. Vladimir's Seminary Press, 2007.

Haimo of Auxerre. Exposition of the Apocalypse of Blessed John. PL 117.

Hilary of Poitiers. Commentary on Matthew. FC 125.

- Tractatus super psalmos [Commentary on the Psalms]. CSEL 22.

Hippolytus of Rome. Commentary on Daniel. Translated by Thomas C.

Schmidt. Charleston, SC: chronicon.net, 2010.

- On Christ and the Antichrist. ANF 5.

In Apocalypsin Iohannis [Anonymous Gloss on the Apocalypse]. CCCM 189B:355-60, 673-77.

Incerti Auctoris Glossa in Apocalypsin. CCSL 108G.

Irenaeus of Lyons. Against Heresies. ANF 1.

Isidore of Seville. De haeresibus [On Heresies]. PLS 4.

. Etymologiae [Etymologies]. PL 82.

Jerome. Against Helvidius. NPNF, 2nd ser., 6.

. Commentary on the Apocalypse. CSEL 49; ANF 6 (under name of Victorinus).

. Commentary on Daniel. Translated by Gleason L. Archer, Jr., as Jerome's Commentary on Daniel. Grand Rapids, MI: Baker, 1958.

—. De nominibus Hebraicis. PL 23.

- Letter 186 to Pope Damasus. PL 22:361-76.

- Letter 53 to Paulinus. NPNF, 2nd ser., 6:96-102.

-. On Hebrew Names. PL 23.

- On Illustrious Men. FC 100.

Julian of Toledo. Foreknowledge of the World to Come. ACW 63.

Martyrdom and Ascension of Isaiah. In Edgar Hennecke, New Testament Apocrypha, 2:642-63. Edited by W. Schneemelcher. Philadelphia: Westminster, 1965. Edited by James H. Charlesworth in The Old Testament Pseudepigrapha, 2:143-76. New York: Doubleday, 1985. 
Origen. Homilies on Leviticus. FC 83.

Paterius. De testimoniis. PL 79:683-916.

Pelagius. Commentary on the Epistle of Paul to Titus. Edited by Alexander Souter as Pelagius's Expositions of Thirteen Epistles of St Paul, vol. 2. Cambridge: Cambridge University Press, 1926.

Préfaces de la Bible Latine. Edited by Donatien de Bruyne. Namur: Godenne, 1920.

Primasius of Hadrumetum. Commentarius in Apocalypsin [Commentary on the Apocalypse]. CCSL 92.

Pseudo-Alcuin. On the Seven Seals. English: Translated by Francis X. Gumerlock in Seven Seals of the Apocalypse: Medieval Texts in Translation, 30-32. Kalamazoo: Medieval Institute Publications, 2009.

Pseudo-Bede. Collectanea Pseudo-Bedae. Edited and translated by Martha Bayless and Michael Lapidge. Scriptores Latini Hiberniae 14 (Dublin: School of Celtic Studies, Dublin Institute of Advanced Studies 1998).

Pseudo-Epiphanius. Sermo de Antichristo [Sermon on Antichrist]. Edited by Giuseppe Frasson. Venice: S. Lazzaro, 1976.

Pseudo-Hippolytus. On the End of the World. ANF 5.

Pseudo-Jerome. Commemoratorium de Apocalpsi Iohannis Apostoli [Handbook on the Apocalypse of the Apostle John]. CCSL 107:159-229. Edited by Grazia Lo Menzo Rapidsarda as Incerti auctoris Commentarius in Apocalypsin. Catania: Centro di studi sull'antico Cristianesmo, 1967, repr. in PLS 4:1850-63; Edited by Kaspar Hartung as Ein Traktat zur Apokalypse des Ap. Johannes in einer Pergamenthandschrift der K. Bibliothek in Bamberg. Bamberg: Gärtner, 1904.

Reference Bible. De enigmatibus ex Apocalypsi Johannis [On the Mysteries of the Apocalypse of John]. CCSL 107:231-95.

- Praefatio et libri de Pentateucho Moysi [Preface and the Books of the Pentateuch of Moses]. CCCM 173.

Scholia in Apocalypsin. Panayiotis Tzamalikos, An Ancient Commentary on the Book of Revelation. A Critical Edition of the Scholia in Apocalypsin. Cambridge: Cambridge University Press, 2013.

Scriptores Hiberniae minores, part 1. CCSL 108B.

The Seven Seals of the Apocalypse: Medieval Texts in Translation. Edited by Francis X. Gumerlock. Kalamazoo, MI: Medieval Institute Publications, 2009.

Students of Cassiodorus [pseudo-Primasius]. Commentary on the Epistle of Paul to Titus. PL 68. 
Tertullian of Carthage. On Prescription against Heretics. ANF 3. . On the Soul. ANF 3.

Testimonies of Gregory the Great on the Apocalypse. PL 79:1107-22.

Theodulph of Orleans. Expositio in Apocalypsin Johannis [Exposition on the Apocalypse of John]. CCSL 107:297-337.

Tyconius of Carthage. The Book of Rules. Translated by William S. Babcock. Atlanta: Scholars, 1989.

- Tyconii Afri Expositio Apocalypseos [Exposition of the Apocalypse]. CCSL 107A.

Victorinus of Pettau. Commentarii in Apocalypsin editio Victorini et recensio Hieronymi [Commentaries on the Apocalypse]. Edited by Johann Haussleiter in Opera, 11-154. CSEL 49; English: Translated by William Weinrich in Latin Commentaries on Revelation, 1-22.

\section{Secondary Sources}

Bischoff, Bernhard. "Turning Points in the History of Latin Exegesis in the Early Irish Church: A.D. 650-800.” Translated by Colm O'Grady in McNamara, Biblical Studies, 73-160.

. "Wendepunkte in der Geschichte der lateinischen Exegese im Frühmittelalter." Sacris Erudiri 6 (1954): 189-270. Repr. in Bernhard Bischoff, Mittelalterliche Studien (Stuttgart: Hiersemann, 1966), 1: 205-73.

Carey, John, Emma Nic Cárthaigh, and Caitríona O’ Dochartaigh, eds. The End and Beyond: Medieval Irish Eschatology. 2 vols. Oakville, CT: Celtic Studies Publications, 2014.

Culleton, R. Gerald. The Reign of Antichrist. Rockford, IL: Tan, 1974.

Darby, Peter, and Faith Wallis, eds. Bede and the Future. Burlington, VT: Ashgate, 2014.

Doyle, Peter. "The Latin Bible in Ireland: Its Origins and Growth," in McNamara, Biblical Studies, 30-45.

Dulaey, Martine. Victorin de Poetovio premier exegete latin. 2 vols. Paris: Institut d'Études Augustiniennes, 1993.

Emmerson, Richard K., and Bernard McGinn, eds. The Apocalypse in the Middle Ages. Ithaca: Cornell University Press, 1992.

Genke, Victor, and Francis X. Gumerlock. Gottschalk and a Medieval Predestination Controversy: Texts Translated from the Latin. Milwaukee: Marquette University Press, 2010.

Gryson, Roger. "Les commentaries patristiques latins de l'Apocalypse." Revue théologique de Louvain 28 (1997): 305-37. 
Gumerlock, Francis X. "Nero Antichrist: Patristic Evidence of the Use of Nero's Name in Calculating the Number of the Beast (Rev 13:18)." Westminster Theological Journal 68 (2006): 347-60.

. "The Number of Nero Antichrist." In Revelation and the First Century, 139-48. Powder Springs, GA: American Vision, 2012.

- Revelation and the First Century: Preterist Interpretations of the Apocalypse in Early Christianity. Powder Springs, GA: American Vision, 2012.

Hill, Charles. "Antichrist from the Tribe of Dan." Journal of Theological Studies 46 (1995): 99-117.

Huchedé, P. History of Antichrist. Rockford, IL: Tan, 1976.

Hughes, Kathleen. "The Distribution of Irish Scriptoria and Centres of Learning from 730 to 1111." In Norah Chadwick, ed., Studies in the Early British Church, 243-72. Cambridge: Cambridge University Press, 1958

James, Montague Rhodes. The Apocryphal New Testament. Oxford: Clarendon Press, 1926.

Junod, Eric. "À propos des soi-disant scolies sur l'Apocalypse d'Origène." Rivista di storia e letteratura religiosa 20 (1984): 112-21.

Kelly, Joseph F. T. "Bede and the Irish Exegetical Tradition on the Apocalypse," Revue bénèdictine 92 (1982): 393-406.

. "A Catalogue of Early Medieval Hiberno-Latin Biblical Commentaries (I).” Traditio 44 (1988): 538-71.

. "A Catalogue of Early Medieval Hiberno-Latin Biblical Commentaries (II)." Traditio 45 (1989-1990): 394-434.

. "Das Bibelwerk: Organization and Quellenanalyse of the New Testament Section." In Ní Chatháin and Richter, Irland und die Christenheit, 113-23.

. "Early Medieval Evidence for Twelve Homilies by Origen on the Apocalypse." Vigiliae Christianae 39 (1985): 273-79.

. "The Hiberno-Latin Study of the Gospel of Luke." In McNamara, Biblical Studies, 10-29.

. "Pelagius, Pelagianism, and the Early Christian Irish." Mediaevalia 4 (1978): 99-124.

. "The Venerable Bede and Hiberno-Latin Exegesis." In Paul E.

Szarmach, ed., Sources of Anglo-Saxon Culture, 65-75. Kalamazoo, MI: Medieval Institute Publications, 1986.

Kendall, Calvin B. "Bede and Islam." In Darby and Wallis, Bede and the Future, 93-114. 
Lerner, Robert E. "The Medieval Return to the Thousand-Year Sabbath." In Richard K. Emmerson and Bernard McGinn, eds., The Apocalypse in the Middle Ages, 51-71. Ithaca: Cornell University Press, 1992. -. "Refreshment of the Saints: The Time after Antichrist as a Station for Earthly Progress in Medieval Thought," Traditio 32 (1976): 97-144.

Lewis, Charleton T., and Charles Short. A Latin Dictionary. New York: Oxford University Press, 1890.

Lorein, G. W. "The Antichrist in the Fathers and Their Exegetical Basis." Sacris Erudiri 42 (2003): 5-60.

MacGinty, Gerard. "The Pentateuch of the Reference Bible: The Problem Concerning Its Sources." In O'Loughlin, Scriptures and Early Medieval Ireland, 163-77.

- The Reference Bible, Das Biebelwerk: inter Pauca problesmata de enigmatibus ex tomis canonicis, nunc prompta sunt Praefatio et libri de Pentateucho Moysi. CCCM 173.

MacKay, Thomas. "Early Christian Millenarianist Interpretation of the Two Witnesses in John's Apocalypse 11:3-13." In John M. Lundquist and Stephen D. Ricks, eds., By Study and Also By Faith, 1:22231. Salt Lake City: Deseret, 1990.

Martin, Lawrence T. "The Verona Homily Collection and Its Irish Connections." In Jacqueline Hamesse, Beverly Mayne Kienzle, Debra L. Stoudt, and Ann T. Thayer, eds., Medieval Sermons and Society: Cloister, City, University, 25-33. Leuven: Féderation Internationale des Instituts d'Études Médiévales, 1998.

Martinez, Francisco Javier. "Eastern Christian Apocalyptic in the Early Muslim Period: Pseudo-Methodius and Pseudo-Athanasius." PhD diss., Catholic University of America, 1985.

Matter, E. Ann. "The Apocalypse in Early Medieval Exegesis." In Emmerson and McGinn, The Apocalypse in the Middle Ages, 38-50.

. "The Pseudo-Alcuinian 'De septem sigillis': An Early Latin Apocalypse Exegesis." Traditio 36 (1981): 111-37.

Matthew, Donald. Atlas of Medieval Europe. New York: Facts on File, 1983.

McGinn, Bernard. The Calabrian Abbot: Joachim of Fiore in the History of Western Thought. New York: Macmillan, 1985.

McNally, Robert E. "Der irische Liber de numeris: Eine Quellenanalyse des pseudo-isidorischen 'Liber de numeris.” PhD diss., Universität München, 1957.

- "The 'Tres Linguae Sacrae' in Early Irish Biblical Exegesis." Theological Studies 19 (1958): 395-403. 
McNamara, Martin. "The Affiliations and Origins of the Catechesis Celtica: An Ongoing Quest." In O'Loughlin, The Scriptures and Early Medieval Ireland, 179-203.

, ed. Biblical Studies: The Medieval Irish Contribution. Dublin: Dominican Publications, 1976.

. "The Irish Tradition of Biblical Exegesis, A.D. 500-800.” In Gerd Van Riel, Carlos Steel, and James McEvoy, eds., Iohannes Scottus Eriugena: The Bible and Hermeneutics, 25-54. Leuven: University Press, 1996.

. "The Newly-Identified Cambridge Apocalypse Commentary and the Reference Bible: A Preliminary Enquiry.” Peritia 15 (2000): 208-56.

. "Plan and Source Analysis of Das Bibelwerk, Old Testament." In Ní Chatháin and Richter, Irland und die Christenheit, 84-112.

- "Sources and Affiliations of the Catechesis Celtica (MS Vat. Reg. lat. 49).” Sacris Erudiri 34 (1994): 185-237.

Mönster, Petrus Joannes. De Dionysii Alexandrini circa apocalypsin Johannean sententia, huiusque vi in seriorem libri aestimationem Observationes. Copenhagen: Andreas Seidelin, 1826.

Ní Chatháin, Próinséas, and Michael Richter, eds. Irland und die Christenheit: Bibelstudien und Mission. Stuttgart: Klett-Cotta, 1966.

Ó Laoghaire, Diarmuid. "Irish elements in the Catechesis Celtica." In Ní Chatháin and Richter, Irland und die Christenheit, 146-64.

O'Loughlin, Thomas, ed. The Scriptures and Early Medieval Ireland. Turnhout: Brepols, 1999.

Palmer, James T. The Apocalypse in the Early Middle Ages. Cambridge: Cambridge University Press, 2014.

. "Rimbert's Vita Anskarii and Scandinavian Mission in the Ninth Century." Journal of Ecclesiastical History 55 (2004): 235-56.

Rapidsarda, Grazia Lo Menzo. "Per una storia dell'esegesi irlandese: Incerti auctoris Commentarius in Apocalypsin," Orpheus 19-20 (199899): 378-94.

Robinson, David Charles. "The Mystic Rules of Scripture: Tyconius of Carthage's Keys and Windows to the Apocalypse." PhD diss., University of St Michael's College, Toronto, 2010.

Steinhauser, Kenneth B. The Apocalypse Commentary of Tyconius: A History of Its Reception and Influence. New York: Peter Lang, 1987.

. "Bemerkungen zum pseudo-hieronymischen Commemoratorium in Apocalysin." Freiburger Zeitschrift für Philosophie und Theologie 26 (1979): 220-42. 
Wallis, Faith. "Why Did Bede Write a Commentary on Revelation?" In Darby and Wallis, Bede and the Future, 23-45.

Weinrich, William. "Antichrist in the Early Church." Concordia Theological Quarterly 49 (1985): 134-47.

. Greek Commentaries on Revelation. Downers Grove, IL: InterVarsity, 2011.

- Latin Commentaries on Revelation. Downers Grove, IL: InterVarsity, 2011.

Williams, John. "Purpose and Imagery in the Apocalypse Commentary of Beatus of Liébana." In Emmerson and McGinn, Apocalypse in the Middle Ages, 217-33.

Williams, P. J. "P115 and the Number of the Beast." Tyndale Bulletin 58: (2007): 151-153.

Young, Frances. Biblical Exegesis and the Formation of Christian Culture. Cambridge: Cambridge University Press, 1997. 
This page intentionally left blank. 


\section{TEAMS Commentary Series}

Haimo of Auxerre, Commentary on the Book of Jonah, translated with an introduction and notes by Deborah Everhart (1993)

Medieval Exegesis in Translation: Commentaries on the Book of Ruth, translated with an introduction and notes by Lesley Smith (1996)

Nicholas of Lyra's Apocalypse Commentary, translated with an introduction and notes by Philip D. W. Krey (1997)

Rabbi Ezra Ben Solomon of Gerona, Commentary on the Song of Songs and Other Kabbalistic Commentaries, selected, translated, and annotated by Seth Brody (1999)

Second Thessalonians: Two Early Medieval Apocalyptic Commentaries, introduced and translated by Steven R. Cartwright and Kevin L. Hughes (2001)

John Wyclif, On the Truth of Holy Scripture, translated with an introduction and notes by Ian Christopher Levy (2001)

The "Glossa Ordinaria" on the Song of Songs, translated with an introduction and notes by Mary Dove (2004)

The Seven Seals of the Apocalypse: Medieval Texts in Translation, translated with an introduction and notes by Francis X. Gumerlock (2009)

The Glossa Ordinaria on Romans, translated with an introduction and notes by Michael Scott Woodward (2011)

Nicholas of Lyra, Literal Commentary on Galatians, edited and translated by Edward Arthur Naumann (2016)

To Order Please Contact:

Medieval Institute Publications

Western Michigan University

Kalamazoo, MI 49008-5432

Phone (269) 387-8755

FAX (269) 387-8750

wmich.edu/medievalpublications 
Typeset in 11/13 Adobe Garamond Pro

Medieval Institute Publications

College of Arts and Sciences

Western Michigan University 1903 W. Michigan Avenue

Kalamazoo, MI 49008-5432

http:/ /www.wmich.edu/medievalpublications

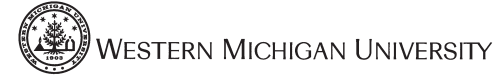

